\title{
Application of the Hybrid Approach to Chronic Total Coronary Occlusion Percutaneous Coronary Intervention
}

\author{
Ph.D. Thesis \\ PÉTER TAJTI M.D. \\ Supervisors: Imre Ungi M.D., Ph.D., Ferenc Tamás Nagy M.D., Ph.D.

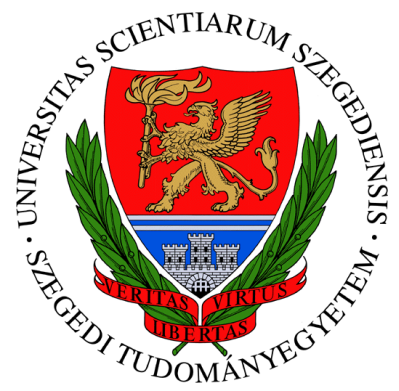

Division of Invasive Cardiology

Second Department of Internal Medicine and Cardiology Center

Faculty of Medicine

University of Szeged

Szeged

2019. 


\section{TABLE OF CONTENTS}

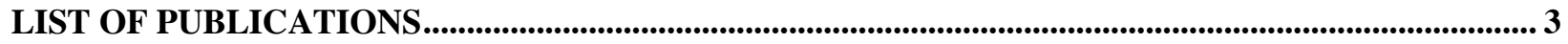

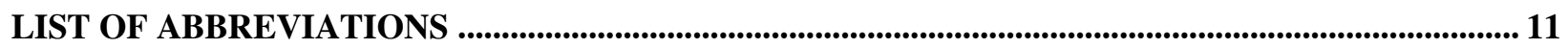

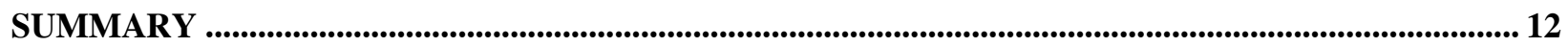

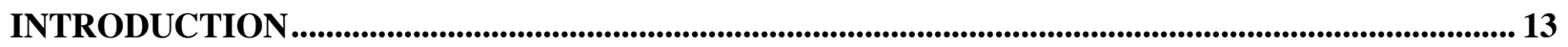

CLINICAL BENEFITS OF CTO PCI - RANDOMIZED STUDIES ................................................................ 13

CLINICAL BENEFITS OF CTO PCI - OBSERVATIONAL STUDIES .............................................................. 15

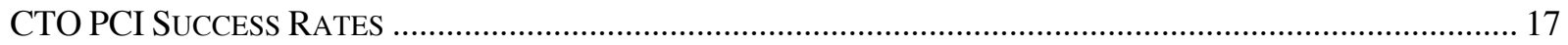

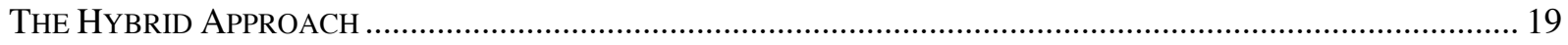

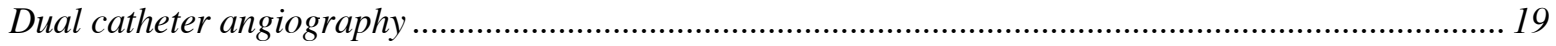

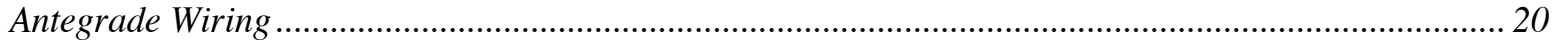

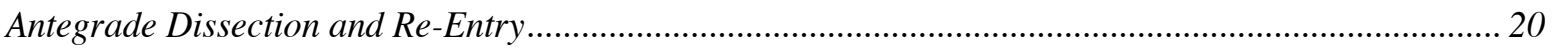

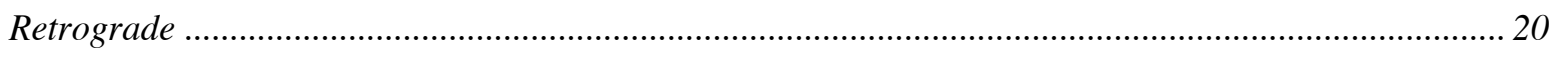

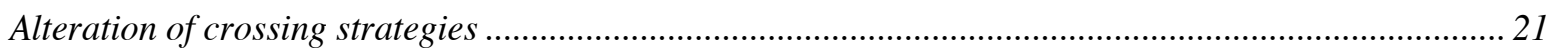

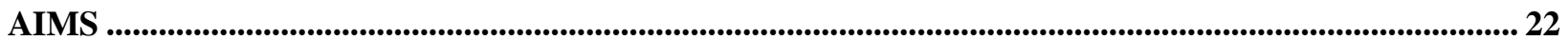

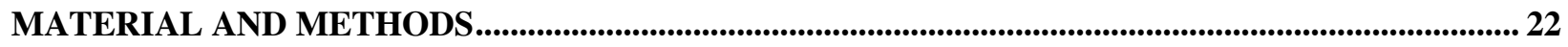

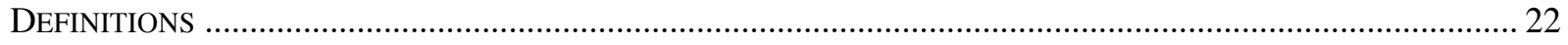

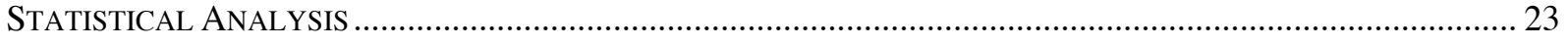

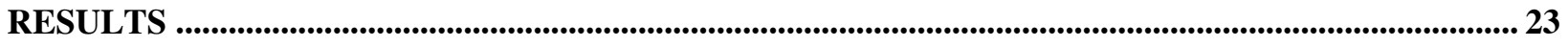

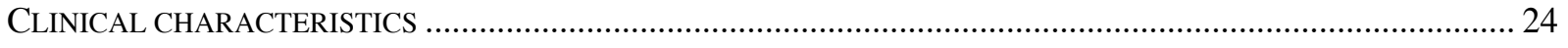

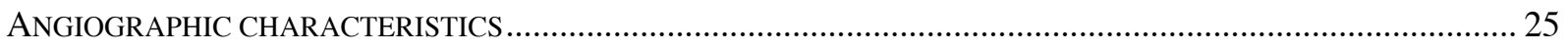

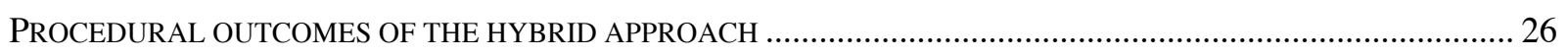

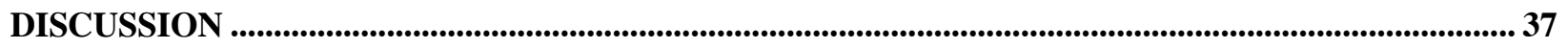

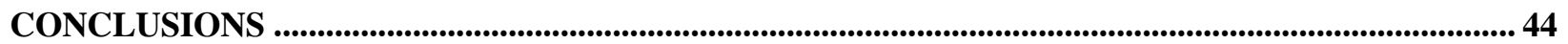

ACKNOWLEDGEMENTS.................................................................................................................................................. 45

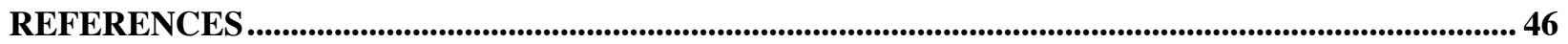




\section{LIST OF PUBLICATIONS}

\section{This doctoral thesis is based on the following publications:}

I. Tajti P, Karmpaliotis D, Alaswad K, Jaffer FA, Yeh RW, Patel M, Mahmud E, Choi JW, Burke MN, Doing AH, Dattilo P, Toma C, Smith AJC, Uretsky B, Holper E, Wyman RM, Kandzari DE, Garcia S, Krestyaninov O, Khelimskii D, Koutouzis M, Tsiafoutis I, Moses JW, Lembo NJ, Parikh M, Kirtane AJ, Ali ZA, Doshi D, Rangan BV, Ungi I, Banerjee S, Brilakis ES. The Hybrid Approach of Percutaneous Coronary Interventions for Chronic Total Occlusions: Update from the PROGRESS-CTO (PROspective Global REgiStry for the Study of Chronic Total Occlusion Intervention) International Registry. JACC Cardiovasc Interv. 2018 Jul 23;11(14):1325-1335. IF : 9.881

II. Tajti P, Ungi I. Az anterográd technikák szerepe a krónikus teljes koszorúér-elzáródás perkután revaszkularizációjában. Cardiologia Hungarica 2018 November; 48(5):330-339.

III. Tajti P, Abu-Fanne R, Ungi I, Katona A, Sasi V, Nagy FT. Kettős lumenú mikrokatéterek alkalmazása krónikus teljes koronária okklúzió katéteres revaszkularizációjában - egy komplex beavatkozás tanulságai. Cardiologia Hungarica 2019 September; [In Press].

Total impact factor of original papers directly related to the thesis: 9.881

\section{Publications not directly related to the thesis:}

I. Tajti P, Alaswad K, Karmpaliotis D, Jaffer FA, Yeh RW, Patel M, Mahmud E, Choi JW, Burke MN, Doing AH, Dattilo P, Toma C, Smith AJC, Uretsky BF, Holper E, Potluri S, Wyman RM, Kandzari DE, Garcia S, Krestyaninov O, Khelimskii D, Koutouzis M, Tsiafoutis I, Khatri JJ, Jaber W, Samady H, Jefferson B, Patel T, Abdullah S, Moses JW, Lembo NJ, Parikh M, Kirtane AJ, Ali ZA, Doshi D, Xenogiannis I, Stanberry LI, Rangan BV, Ungi I, Banerjee S, Brilakis ES. Procedural Outcomes of Percutaneous Coronary Interventions for Chronic Total Occlusions via the Radial Approach: Insight from an International CTO Registry. JACC Cardiovasc Interv. 2019 Feb 25;12(4):346-358. IF: 9.881 
II. Tajti P, Karmpaliotis D, Alaswad K, Jaffer FA, Yeh RW, Patel M, Mahmud E, Choi JW, Burke MN, Doing AH, Dattilo P, Toma C, Smith AJC, Uretsky BF, Holper E, Potluri S, Wyman RM, Kandzari DE, Garcia S, Krestyaninov O, Khelimskii D, Koutouzis M, Tsiafoutis I, Khatri JJ, Jaber W, Samady H, Moses JW, Lembo NJ, Parikh M, Kirtane AJ, Ali ZA, Doshi D, Xenogiannis I, Stanberry LI, Rangan BV, Ungi I, Banerjee S, Brilakis ES. In-hospital Outcomes of Chronic Total Occlusion Percutaneous Coronary Interventions in Patients with Prior Coronary Artery Bypass Graft Surgery: Insights from an International Multicenter CTO Registry. Circ Cardiovasc Interv. 2019 Mar;12(3):e007338. IF : 6.504

III. Tajti P, Xenogiannis I, Chavez I, Gössl M, Mooney M, Poulose A, Sorajja P, Traverse J, Wang Y, Burke MN, Brilakis ES. Expecting the unexpected: preventing and managing the consequences of coronary perforations. Expert Rev Cardiovasc Ther. 2018 Nov;16(11):805-814. IF: 1.67

IV. Tajti P, Xenogiannis I, Karmpaliotis D, Alaswad K, Jaffer FA, Burke MN, Ungi I, Brilakis ES. Chronic total occlusions: update on current tips and tricks. Curr Cardiol Rep. 2018 Oct 22;20(12):141. IF : 1.958

V. Tajti P, Burke MN, Karmpaliotis D, Alaswad K, Jaffer FA, Yeh RW, Patel M, Mahmud E, Choi JW, Doing AH, Datilo P, Toma C, MD, Smith AJC, Uretsky B, Holper E, Garcia S, Krestyaninov O, Khelimskii D, Koutouzis M, Tsiafoutis I, Moses JW, Lembo NJ, Parikh M, Kirtane AJ, Ali ZA, Doshi D, Jaber W, Samady H, Rangan BV, Xenogiannis I, Ungi I, Banerjee S, Brilakis ES. Prevalence and Outcomes of Percutaneous Coronary Interventions for Ostial Chronic Total Occlusions: Insights from a Multicenter CTO Registry. Can J Cardiol. 2018 Oct;34(10):1264-1274. IF: 4.524

VI. Tajti P, Brilakis ES. Medical simulation in interventional cardiology: "More research is needed". Catheter Cardiovasc Interv. 2018;91:1060-1061.

VII. Tajti P, Karatasakis A, Danek BA, Alaswad K, Karmpaliotis D, Jaffer FA, Choi JW, Yeh RW, Patel MP, Mahmud E, Burke MN, Krestyaninov O, Khelimskii D, Toma C, Doing AH, Uretsky B, Koutouzis M, Tsiafoutis I, Wyman RM, Garcia S, Holper E, Xenogiannis I, Rangan BV, Banerjee S, Ungi I, Brilakis ES. In-Hospital Outcomes of Chronic Total 
Occlusion Percutaneous Coronary Intervention in Patients with Chronic Kidney Disease. J Invasive Cardiol. 2018 Nov;30(11):E113-E121. IF: 1.537

VIII. Tajti P, Alaswad K, Karmpaliotis D, Jaffer FA, Yeh RW, Patel MP, Mahmud E, Choi JW, Burke MN, Doing AH, Toma C, Uretsky B, Holper E, Wyman, MR, Kandzari DE, Garcia S, Krestyaninov O, Khelmiskii D, Koutouzis M, Tsiafoutis I, Jaber W, Samady H, Moses JW, Lembo NJ, Parikh M, Kirtane AJ, Ali ZA, Doshi D, Xenogiannis I, Rangan BV, Ungi I, Banerjee S, Brilakis ES. In-hospital Outcomes of Attempting More Than One Chronic Total Coronary Occlusion Via Percutaneous Intervention During the Same Procedure. Am J Cardiol. 2018 Aug 1;122(3):381-387. IF: 3.171

IX. Tajti P, Burke MN, Karmpaliotis D, Alaswad K, Werner GS, Azzalini L, Carlino M, Patel M, Mashayekhi K, Egred M, Krestyaninov O, Khelimskii D, Nicholson WJ, Ungi I, Galassi AR, Banerjee S, Brilakis ES. Update in the Percutaneous Management of Coronary Chronic Total Occlusions. JACC Cardiovasc Interv. 2018 Apr 9;11(7):615-625. IF: 9.881

X. Tajti P, Brilakis ES. Chronic Total Occlusion Percutaneous Coronary Intervention: Evidence and Controversies. J Am Heart Assoc. 2018 Jan 12; 7(2). IF: 4.45

XI. Tajti P, Karatasakis A, Karmpaliotis D, Alaswad K, Jaffer FA, Yeh RW, Patel M, Mahmud E, Choi JW, Doing AH, Toma C, Uretsky B, Garcia S, Moses JW, Parikh M, Kirtane A, Ali ZA, Hatem R, Karacsonyi J, Danek BA, Rangan BV, Banerjee S, Ungi I, Brilakis ES. Retrograde CTO-PCI of Native Coronary Arteries Via Left Internal Mammary Artery Grafts: Insights From a Multicenter U.S. Registry. J Invasive Cardiol. 2018 Mar;30(3):8996. IF: 1.537

XII. Tajti P, Karmpaliotis D, Alaswad K, Toma C, Choi JW, Jaffer FA, Doing AH, Patel M, Mahmud E, Uretsky B, Karatasakis A, Karacsonyi J, Danek BA, Rangan BV, Banerjee S, Ungi I, Brilakis ES. Prevalence, Presentation and Treatment of 'Balloon Undilatable' Chronic Total Occlusions: Insights from a Multicenter US Registry. Catheter Cardiovasc Interv. 2018 Mar 1; 91(4):657-666. IF: 2.602

XIII. Tajti P, Doshi D, Karmpaliotis D, Brilakis ES. The "double stingray technique" for recanalizing chronic total occlusions with bifurcation at the distal cap. Catheter Cardiovasc Interv. 2018 May 1;91(6):1079-1083. IF: 2.602 
XIV. Tajti P, Sandoval Y, Brilakis ES. "Around the world" - How to reach native coronary artery lesions through long and tortuous aortocoronary bypass grafts. Hellenic J Cardiol. 2018 Jan 3. pii: S1109-9666(17)30607-3. [Epub ahead of print] IF : 1.89

XV. Tajti P, Brilakis ES. Percutaneous Treatment of Coronary Perforation in Acutely Occluded Right Coronary Artery after Reimplantation in the Aortic Root. Hellenic J Cardiol 2018 May 25. pii: S1109-9666(18)30130-1. [Epub ahead of print] IF: 1.89

XVI. Tajti P, Brilakis ES. Does the hybrid algorithm have real impact on long-term outcomes or should only be used as a valuable approach for CTO crossing? J Thorac Dis. 2018;10:1320-1324.

XVII. Tajti P, Xenogiannis I, Hall A, Burke MN, Chavez I, Garcia S, Gössl M, Mooney M, Poulose A, Sorajja P, Wang Y, Vemmou E, Nikolakopoulos I, Morley P, Rangan BV, Ungi I, Brilakis ES. Use of the DyeVert System in Chronic Total Occlusion Percutaneous Coronary Intervention. J Invasive Cardiol 2019 [In Press] 1.537

XVIII. Tajti P, Brilakis ES. Retrograde via epicardial collaterals: With power comes responsibility. J Interv Cardiol 2018;31:31-32.

XIX. Tajti P, Xenogiannis I, Najar H, Brilakis ES. Management of Balloon Undilatable CTOs. Cardiac Interventions Today May/June 2018.

XX. Sandoval Y, Tajti P, Karatasakis A, Burke MN, Danek BA, Karmpaliotis D, Alaswad K, Jaffer FA, Yeh RW, Patel M, Mahmud E, Krestyaninov O, Khelimskii D, Choi JW, Doing AH, Toma C, Wyman RM, Uretsky B, Garcia S, Koutouzis M, Tsiafoutis I, Holper E, Moses JW, Lembo NJ, Parikh M, Kirtane AJ, Ali ZA, Doshi D, Kandzari DE, Karacsonyi J, Rangan BV, Thompson C, Banerjee S, Brilakis ES. Frequency and Outcomes of Ad Hoc Versus Planned Chronic Total Occlusion Percutaneous Coronary Intervention: Multicenter Experience. J Invasive Cardiol. 2019 May;31(5):133-139. IF: 1.537

XXI. Xenogiannis I, Tajti P, Hall A, Alaswad K, Rinfret S, Nicholson W, Karmpaliotis D, Mashayekhi K, Furkalo S, Cavalcante J, Burke MN, Brilakis ES. Update on Cardiac Catheterization in Patients With Prior Coronary Artery Bypass Graft Surgery. JACC Cardiovasc Interv. 2019 [In Press]. IF : 9.881 
XXII. Xenogiannis I, Tajti P, Burke MN, Chavez I, Gössl M, Mooney M, Poulose A, Sorajja P, Traverse J, Wang Y, Brilakis ES. Coronary Revascularization and Use of Hemodynamic Support in Acute Coronary Syndromes. Hellenic J Cardiol. 2019 Jan 21. pii: S11099666(18)30490-1. doi: 10.1016/j.hjc.2019.01.010. [Epub ahead of print] IF: 1.89

XXIII. Xenogiannis I, Karmpaliotis D, Alaswad K, Jaffer FA, Yeh RW, Patel M, Mahmud E, Choi JW, Burke MN, Doing AH, Dattilo P, Toma C, Smith AJC, Uretsky B, Krestyaninov O, Khelimskii D, Holper E, Potluri S, Wyman RM, Kandzari DE, Garcia S, Koutouzis M, Tsiafoutis I, Jaber W, Samady H, Moses JW, Lembo NJ, Parikh M, Kirtane AJ, Ali ZA, Doshi D, Tajti P, Rangan BV, Abdullah S, Banerjee S, Brilakis ES. Comparison Between Traditional and Guide-Catheter Extension Reverse Controlled Antegrade Dissection and Retrograde Tracking: Insights From the PROGRESS-CTO Registry. J Invasive Cardiol. 2019 Jan;31(1):27-34. IF : 1.537

XXIV. Xenogiannis I, Karmpaliotis D, Alaswad K, Jaffer FA, Yeh RW, Patel M, Mahmud E, Choi JW, Burke MN, Doing AH, Dattilo P, Toma C, Smith AJC, Uretsky B, Krestyaninov O, Khelimskii D, Holper E, Potluri S, Wyman RM, Kandzari DE, Garcia S, Koutouzis M, Tsiafoutis I, Khatri JJ, Jaber W, Samady H, Jefferson BK, Patel T, Moses JW, Lembo NJ, Parikh M, Kirtane AJ, Ali ZA, Doshi D, Tajti P, Rangan BV, Abdullah S, Banerjee S, Brilakis ES. Usefulness of Atherectomy in Chronic Total Occlusion Interventions (from the PROGRESS-CTO Registry). Am J Cardiol. 2019 May 1;123(9):1422-1428. IF : 3.171

XXV. Xenogiannis I, Tajti P, Nicholas Burke M, Brilakis ES. An alternative treatment strategy for large vessel coronary perforations. Catheter Cardiovasc Interv. 2019 Mar 1;93(4):635638. IF : 2.602

XXVI. Xenogiannis I, Tajti P, Burke MN, Brilakis ES. Staged revascularization in patients with acute coronary syndromes due to saphenous vein graft failure and chronic total occlusion of the native vessel: A novel concept. Catheter Cardiovasc Interv. 2019 Feb 15;93(3):440444. IF : 2.602

XXVII. Karacsonyi J, Tajti P, Rangan BV, Halligan SC, Allen RH, Nicholson WJ, Harvey JE, Spaedy AJ, Jaffer FA, Grantham JA, Salisbury A, Hart AJ, Safley DM, Lombardi WL, Hira R, Don C, McCabe JM, Burke MN, Alaswad K, Koenig GC, Sanghvi KA, Ice D, Kovach RC, Varghese V, Murad B, Baran KW, Resendes E, Martinez-Parachini JR, 
Karatasakis A, Danek BA, Iwnetu R, Roesle M, Khalili H, Banerjee S, Brilakis ES. Randomized Comparison of a CrossBoss First Versus Standard Wire Escalation Strategy for Crossing Coronary Chronic Total Occlusions: The CrossBoss First Trial. JACC Cardiovasc Interv. 2018 Feb 12; 11(3):225-233. IF : 9.881

XXVIII. Xenogiannis I, Tajti P, Karmpaliotis D, Garbo R, Gagnor A, Burke MN, Brilakis ES. Intravascular imaging for chronic total occlusion intervention. Curr Cardiovasc Imaging Rep (2018) 11: 31 .

XXIX. Xenogiannis I, Karmpaliotis D, Alaswad K, Jaffer FA, Yeh RW, Patel M, Mahmud E, Choi JW, Burke MN, Doing AH, Dattilo P, Toma C, Uretsky B, Krestyaninov O, Khelimskii D, Holper E, Potluri S, Wyman RM, Kandzari DE, Garcia S, Koutouzis M, Tsiafoutis I, Khatri JJ, Jaber W, Samady H, Jefferson BK, Patel T, Moses JW, Lembo NJ, Parikh M, Kirtane AJ, Ali ZA, Gkargkoulas F, Tajti P, Hall AB, Rangan BV, Abdullah S, Banerjee S, Brilakis ES. Impact of concomitant treatment of non-chronic total occlusion lesions at the time of chronic total occlusion intervention. Int J Cardiol. 2019 Jul 3. [Epub ahead of print] IF $: 4.034$

XXX. Xenogiannis I, Karmpaliotis D, Alaswad K, Basir MB, Yeh RW, Tamez H, Patel M, Mahmud E, Choi JW, Burke MN, Doing AH, Dattilo P, Khatri JJ, Sheikh AM, Malik BA, Greene ME, Abi Rafeh N, Maalouf A, Abou Jaoudeh F, Moses JW, Lembo NJ, Parikh M, Kirtane AJ, Ali ZA, Gkargkoulas F, Russo J, Hakemi E, Tajti P, Hall AB, Vemmou E, Nikolakopoulos I, Rangan BV, Abdullah S, Banerjee S, Brilakis ES. Left Main Chronic Total Occlusion Percutaneous Coronary Intervention: A Case Series. J Invasive Cardiol. 2019 Jul;31(7):E220-E225. IF: 1.537

XXXI. Shaukat A, Hryniewicz-Czeneszew K, Sun B, Mudy K, Wilson K, Tajti P, Stanberry L, Garberich R, Sandoval Y, Burke MN, Chavez I, Gössl M, Henry T, Lips D, Mooney M, Poulose A, Sorajja P, Traverse J, Wang Y, Bradley S, Brilakis ES. Outcomes of Extracorporeal Membrane Oxygenation Support for Complex High-Risk Elective Percutaneous Coronary Interventions: A Single-Center Experience and Review of the Literature. J Invasive Cardiol. 2018 Dec;30(12):456-460. IF : 1.537

XXXII. Shaukat A, Tajti P, Sandoval Y, Stanberry L, Garberich R, Nicholas Burke M, Gössl M, Henry T, Mooney M, Sorajja P, Traverse J, Bradley SM, Brilakis ES. Incidence, predictors, 
management and outcomes of coronary perforations. Catheter Cardiovasc Interv. 2019 Jan $1 ; 93(1): 48-56 . I F: 2.602$

XXXIII. Ungi I, Tajti P, Hausinger I, Katona A, Sasi V, Thury A. The retrograde approach to coronary chronic total occlusion interventions. Journal of Continuing Education in Cardiology 2015, 1:10-18.

XXXIV. Danek BA, Karatasakis A, Tajti P, Sandoval Y, Karmpaliotis D, Alaswad K, Jaffer F, Yeh RW, Kandzari DE, Lembo NJ, Patel MP, Mahmud E, Choi JW, Doing AH, Lombardi WL, Wyman RM, Toma C, Garcia S, Moses JW, Kirtane AJ, Hatem R, Ali ZA, Parikh M, Karacsonyi J, Rangan BV, Khalili H, Burke MN, Banerjee S, Brilakis ES. Incidence, Treatment, and Outcomes of Coronary Perforation During Chronic Total Occlusion Percutaneous Coronary Intervention. Am J Cardiol. 2017 Oct 15; 120(8):1285-1292. IF: 3.171

XXXV. Azzalini L, Karatasakis A, Spratt JC, Tajti P, Riley RF, Ybarra LF, Schumacher SP, Benincasa S, Bellini B, Candilio L, Mitomo S, Henriksen P, Hidalgo F, Timmers L, Kraaijeveld AO, Agostoni P, Roy J, Ramsay DR, Weaver JC, Knaapen P, Nap A, Starcevic B, Ojeda S, Pan M, Alaswad K, Lombardi WL, Carlino M, Brilakis ES, Colombo A, Rinfret S, Mashayekhi K. Subadventitial stenting around occluded stents: A bailout technique to recanalize in-stent chronic total occlusions. Catheter Cardiovasc Interv. 2018 Sep 1;92(3):466-476. IF: 2.602

XXXVI. Sandoval Y, Lobo AS, Somers VK, Rosenfield K, Bradley SM, Sorajja P, Tajti P, Brilakis ES. Sleep deprivation in interventional cardiology: Implications for patient care and physician-health. Catheter Cardiovasc Interv. 2018 Apr 1;91(5):905-910. IF: 2.602

XXXVII. Sandoval Y, Lobo AS, Tajti P, Brilakis ES. Laser-assisted orbital or rotational atherectomy: a hybrid treatment strategy for balloon-uncrossable lesions. Hellenic J Cardiol. 2018 Aug 6. [Epub ahead of print] IF: 1.89

XXXVIII. Megaly M, Saad M, Tajti P, Burke MN, Chavez I, Gössl M, Lips D, Mooney M, Poulose A, Sorajja P, Traverse J, Wang Y, Kohl LP, Bradley SM, Brilakis ES. Meta-analysis of the impact of successful chronic total occlusion percutaneous coronary intervention on left 
ventricular systolic function and reverse remodeling. J Interv Cardiol. 2018 Oct;31(5):562$571 . I F: 1.728$

XXXIX. Iverson A, Stanberry LI, Tajti P, Garberich R, Antos A, Burke MN, Chavez I, Gössl M, Henry TD, Lips D, Mooney M, Poulose A, Sorajja P, Traverse J, Wang Y, Bradley S, Brilakis ES. Prevalence, trends, and outcomes of higher risk percutaneous coronary interventions among patients without acute coronary syndromes. Cardiovasc Revasc Med. 2019 Apr;20(4):289-292. IF: 0.15

XL. Najar H, Tajti P, Xenogiannis L, Brilakis E. CTO complexity begets complexity. Cath Lab Digest.2018 May; 26(5):1, 18-22.

XLI. Vemmou E, Nikolakopoulos I, Xenogiannis I, Tajti P, Hall A, Brilakis ES. The Gordian Knot-If You Cannot Solve it, Cut it: Treating Guidewire Bending While Obtaining Arterial Access. JACC Cardiovasc Interv. 2019 May 13;12(9):892-893.

Total impact factor of original papers not related to the thesis: 110.588 


\section{LIST OF ABBREVIATIONS}

ADR - antegrade dissection and re-entry

AK - air kerma

AWE - antegrade wire escalation

BMI - body mass index

CABG - coronary artery bypass graft

CAD - coronary artery disease

CART - controlled antegrade and retrograde subintimal tracking

CCS - Canadian Cardiovascular Society Angina Classification

CI - confidence interval

cMRI - cardiac magnetic resonance imaging

CPX - cardiopulmonary exercise

CTO - chronic total occlusion

CVD - cerebrovascular disease

DES - drug eluting stent

DV - donor vessel

$\mathrm{HF}$ - heart failure
J-CTO - Japanese Chronic Total Occlusion

LAD - left anterior descending artery

LCX -left circumflex artery

LM - left main

LVEF - left ventricular ejection fraction

MACE - major adverse cardiac event

MI - myocardial infarction

MIB - myocardial ischemic burden

OMT - optimal medical treatment

OR - odds ratio

PVD -peripheral arterial disease

PCI - percutaneous coronary intervention

QoL - quality of life

RCA -right coronary artery

SAQ - Seattle Angina Questionnaire

SWT - segmental wall thickening

TVR - target vessel revascularization 


\section{SUMMARY}

Percutaneous coronary intervention (PCI) for chronic total occlusion (CTO) continues to evolve constantly with developing equipment and techniques. The hybrid approach to CTO PCI advocates dual coronary injection, careful and structured review of the angiogram, and flexibility. Use of all crossing strategies [antegrade wire escalation, antegrade dissection re-entry and retrograde approach] is encouraged, with initial and subsequent choices influenced by the CTO anatomic characteristics and the outcomes of the originally selected approach. Application of the hybrid approach to CTO PCI has been associated with good outcomes in US and European registries, although CTO PCI outcomes in non-selected populations have been less optimal with approximately $60 \%$ success rate.

We analyzed the clinical, angiographic, and procedural characteristics of 3,122 CTO PCIs performed in 3,055 patients to determine the techniques and outcomes of hybrid CTO PCI in a diverse group of patients and operators in two continents (at eighteen US, one European, and one Russian centers ) enrolled in the PROGRESS-CTO (PROspective Global REgiStry for the Study

of Chronic Total Occlusion Intervention, NCT02061436) registry between January 2012 and November 2017.

Technical success rate was $87 \%$ and the risk for in-hospital major complications was $3 \%$, providing important benchmarks to use when discussing with patients and providers the risk/benefit ratio of CTO PCI. The final successful crossing strategy was antegrade wire escalation in $52 \%$, retrograde in $27 \%$, and antegrade dissection reentry in $21 \%$; more than 1 crossing strategies were required in $41 \%$ of the cases.

CTO PCI is currently being performed with high success and acceptable complication rates among various experienced centers in the US and Europe. Bridging the gap between what is currently achieved and what can be achieved in chronic total occlusion intervention should be a major focus of upcoming research and education efforts. 


\section{INTRODUCTION}

Coronary chronic total occlusions (CTOs) are defined as $100 \%$ occlusions with TIMI 0 flow with at least 3 month duration (1). Treatment options for patients with coronary CTOs include lifestyle changes, medications (as is appropriate for all patients with coronary artery disease) and coronary revascularization with either percutaneous coronary intervention (PCI) or coronary bypass graft surgery (CABG). Chronic total occlusion (CTO) percutaneous coronary intervention (PCI) is a rapidly evolving area of interventional cardiology that has undergone a remarkable technical improvement over the past two decades.

CTOs are found in 15-25\% of patients undergoing coronary angiography who are found to have coronary artery disease (2-4) in various large cohorts. In a more recent study from SCAAR (Swedish Coronary Angiography and Angioplasty Registry), the prevalence of CTO among patients with at least one $50 \%$ luminal coronary stenosis was $16.1 \%$ (14441 of 89872 patients) (5). In a Canadian single center registry the prevalence of a CTO was $20 \%$, however PCI was only performed in $9 \%$ of these patients whereas majority of them had CABG (34\%) or were treated with medical therapy alone (57\%) (6). Treatment of CTO with PCI currently remains less preferred in clinical practice possibly due to the limited operator expertise, high procedural cost, limited cardiac catheterization laboratory time availability, high risk for procedural complications and the ongoing controversy regarding its clinical benefits.

In the previous version of the appropriateness use criteria for coronary revascularization (7) revascularization recommendations were different for patients with and without a coronary CTO. This is no longer the case in the current (2016 and 2017) versions (8,9). The novel ESC/EACTS 2018 guidelines recommends Class II a (level of evidence B) for percutaneous CTO revascularization: "CTO PCI should be considered in patients with angina resistant to medical therapy or with a large area of documented ischemia in the territory of the occluded vessel"(10).

\section{Clinical benefits of CTO PCI - randomized studies}

Currently, symptom improvement is considered the main benefit of CTO PCI, despite criticisms that there is limited supportive prospective randomized-controlled clinical trial data. Indeed, only five randomized-controlled trials have been published (11-15).

The Evaluating Xience and Left Ventricular Function in Percutaneous Coronary Intervention on OccLusiOns AfteR ST-Elevation Myocardial Infarction trial (EXPLORE; 
NTR1108) enrolled 304 patients who underwent primary PCI for acute ST-segment elevation acute myocardial infarction and had a coexisting non-infarct related artery CTO. Patients were randomized to CTO PCI vs. medical therapy alone. CTO PCI success was $73 \%$. Cardiac magnetic resonance imaging (cMRI) performed after 4 months showed similar left ventricular ejection fraction and left ventricular end-diastolic volume in the two study groups (11).

The RandomizEd Trial to Assess Regional Left Ventricular Function After Stent Implantation in Chronic Total Occlusion trial (REVASC; NCT01924962) sought to investigate the impact of successful CTO PCI on left ventricular function. The study randomized 205 patients to CTO PCI or non-CTO PCI arms (OMT-only) with a primary endpoint of segmental wall thickening (SWT), change in left ventricular volume (LVV) and ejection fraction (LVEF) assessed with cMRI performed at baseline and at 6 months. The trial presented similar change in SWT, regional and global left ventricular function both in CTO and non-CTO PCI groups. Subgroup analysis, however, showed a significant improvement in SWT amongst patients with a CTO without major non-CTO lesion. In hospital major adverse cardiac event (MACE) rate was also significantly higher in the OMT group (16.3\% vs. 5.9\%, p=0.02) (14). The limitation of the study includes the relatively high baseline LVEF in both study arms (PCI group: 59.6\% [IQR 45.8 to 64.3] $54.7 \%$ [IQR 42.9 to 65.1 ], $\mathrm{p}=0.48$ ) and it was underpowered to identify hard clinical endpoints such as cardiac death or MI.

The Drug-Eluting stent Implantation versus optimal MediCal Treatment In patients with ChronIc Total OccluSION (DECISION-CTO; NCT01078051) trial randomized 834 patients with coronary CTOs (many of whom also had multivessel disease) to OMT (optimal medical therapy) alone vs. OMT + CTO-PCI. Patients in the OMT and the OMT + CTO PCI group had similar clinical outcomes during a median follow-up of 3.1 years (primary study endpoint was the composite of death, myocardial infarction, stroke or any revascularization). The study has several limitations, such as suboptimal primary endpoint selection, high rate non-CTO PCI (73\% of the study patients had multivessel disease in both groups), early termination before achievement of target enrollment, high cross-over rates (18\% in the OMT alone group underwent CTO PCI), and mild baseline symptoms in both study groups (12).

The Randomized Multicenter Trial to Evaluate the Utilization of Revascularization or Optimal Medical Therapy for the Treatment of Chronic Total Coronary Occlusions trial (EUROCTO; NCT01760083) aimed to randomize 1,200 patients to either CTO PCI versus OMT- 
only groups with a primary endpoint of health status change assessed by the Seattle Angina Questionnaire (SAQ) at 12 months of follow-up. Due to slow enrollment the study ended prematurely after randomizing 407 patients instead of the 1,200 population. In contrast to DECISION-CTO, non-CTO lesions were treated before enrollment in the study. Compared with patients randomized to medical therapy only, patients randomized to CTO PCI had more improvement in angina frequency (5.23 OR, CI $95 \% 1.75$ to $8.71, \mathrm{p}=0.003$ ), and quality of life (QoL) (6.62 OR, CI 95\% 1.78 to $11.46, \mathrm{p}=0.007$ ) (13).

The Impact on Inducible Myocardial Ischemia of PercutAneous Coronary InTervention versus Optimal Medical TheRapy in Patients with Right Coronary Artery Chronic Total Occlusion (IMPACTOR-CTO) randomized patients with exclusively right coronary artery (RCA) CTOs to PCI ( $n=39$ ) or OMT-only ( $n=33$ ) groups with endpoints of change in myocardial ischemic burden (MIB) (primary endpoint, assessed with cMRI), and 6 minute walking test (6MWT), quality of life (QoL) and MACE (secondary endpoints) at 12 months of follow-up. In the PCI group, myocardial ischemic burden showed significant decrease $(27.7 \pm 8.5 \%$ to $16.1 \pm 8.6 \%, \mathrm{p}<0.01)$, in comparison with the OMT group $(28.4 \pm 6.1 \%$ vs. $27.0 \pm 8,0, \mathrm{p}=0.83)$ without significant change. Functional status and QoL also significantly improved in PCI group but not the OMT group.

Although randomized-controlled clinical trials are the gold standard for determining the efficacy and safety of an intervention, only 15\% of the current American College of Cardiology/American Heart Association guideline recommendations are based on level A evidence (16). Therefore, in the majority of cases, clinical decision making relies on less robust clinical evidence, such as retrospective and observational studies.

\section{Clinical benefits of CTO PCI - observational studies}

Several observational, uncontrolled studies have suggested clinical benefit with CTO PCI, by improving angina, dyspnea, depression, exercise capacity, and risk for arrhythmias.

The OPEN-CTO (Outcomes, Patient Health Status, and Efficiency in Chronic Total Occlusion Hybrid Procedures) registry analyzed 1,000 consecutive patients undergoing CTO PCI with the hybrid approach using standardized questionnaires. A 10.8 (95\% confidence interval [CI]: 6.3 to 15.3) point improvement in the QoL domain of the Seattle Angina Questionnaire (SAQ) was observed among successful vs. unsuccessful procedures $(\mathrm{p}<0.001)(17)$. 
Similar results have been shown in multiple prior studies and meta-analyses, that have also reported lower mortality among successful vs. failed CTO PCIs (18). Several studies have assessed the long-term outcomes of CTO PCI as compared with medical therapy, reporting lower incidence of major adverse cardiac events with CTO PCI $(19,20)$, even among patients with well-developed collateral circulation (21). Several other retrospective studies have compared the outcomes of CTO PCI with medical therapy. In an Italian multicenter registry of 1,777 patients with CTOs treatment was as follows: PCI (43.7\%), MT (medical therapy, $46.5 \%)$, or surgery $(9.8 \%)$. At 1-year followup, cardiac death $(1.4 \%$ vs. $4.7 \%$ and $6.3 \%, \mathrm{p}<0.001)$ and major adverse cardiac events (MACE, $2.6 \%$ vs. $8.2 \%$ and $6.9 \%, \mathrm{p}<0.001$ ) were significantly lower in the PCI group, than in MT or CABG group (19). In propensity-matched analysis MT was associated with higher MACE rate, death, and rehospitalization (19).

Patients with CTOs often have depression that improves after successful CTO PCI (22).

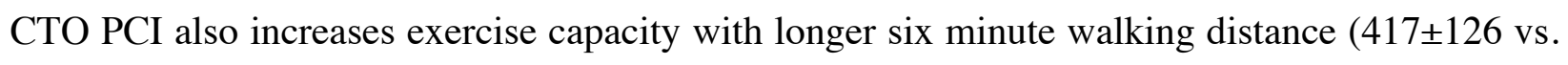
$463 \pm 103 \mathrm{~m}, \mathrm{p}=0.002$ ) in one study, likely due to lower angina frequency ( $39 \%$ vs. $8 \% \mathrm{p}<0.001$ ) and less ischemia, especially in patients with larger baseline ischemic burden (23). Two studies performed cardiopulmonary testing before and after CTO PCI, showing increased peak oxygen consumption and anaerobic threshold $(24,25)$. CTOs may be associated with higher arrhythmic risk: patients with prior myocardial infarction and a CTO had greater area of scar tissue $\left(34 \mathrm{~cm}^{2}\right.$ vs. $\left.19 \mathrm{~cm}^{2}, \mathrm{P}=0.001\right)$ and higher frequency of recurrent ventricular tachycardia after ablation during a median follow up of 19 months (47\% vs. $16 \%, \mathrm{p}=0.003)$ (26).

A recent meta-analysis focused on comparing CTO PCI to OMT including only the available randomized controlled trials (RCT) and propensity score matched (PSM) observational studies to date. A pooled analysis of eight studies (4 RCT and 4 PSM studies) with a total number of 3,971 patients were included (PCI arm $[n=2,050]$ and OMT arm $[n=1,921]$ ). CTO PCI was associated with more favorable outcomes in terms of cardiac death $(0.52 \mathrm{OR}, \mathrm{CI} 95 \% 0.01$ to 0.81 , $\mathrm{p}<0.01)$ - mostly driven by the PSM studies, however, there were no difference in terms of overall MACE, re-PCI or acute MI (27).

CTO PCI improves patient symptoms, whereas there is limited, retrospective data on whether it can impact the subsequent incidence of death, myocardial infarction and arrhythmias. Accordingly, the key indication for offering and performing CTO PCI should be the alleviation of symptoms. 


\section{CTO PCI Success Rates}

Achieving clinical benefit with CTO PCI requires the procedure to be successful. With contemporary equipment and techniques (such as the hybrid algorithm (28)), high success rates (85-90\%) are achieved at experienced centers (29-35). However, success rates in unselected populations remain low: $61.3 \%$ in the New York State PCI Registry (36) and 59\% in the National Cardiovascular Data Registry in the US (vs. 96\% in non-occlusive lesions, p<0.001) (37). Therefore, there is a gap between what is achieved at dedicated CTO PCI centers and the outcomes at less experienced centers.

Patient-specific estimation of the likelihood of success can be facilitated by using various scoring systems. The first CTO PCI score was the J-CTO score (Multicenter CTO Registry of Japan) that was developed to estimate the likelihood of successful guidewire crossing within 30 minutes based on 5 criteria (intralesional $>45^{\circ}$ bend, length $>20 \mathrm{~mm}$, calcification, blunt stump, and previously failed attempt) (38). The J-CTO score has been validated in other CTO PCI cohorts (39) and is also associated with 1-year and 5-year clinical outcomes $(40,41)$.

Other scores include the PROGRESS-CTO (PROspective Global REgiStry for the Study of Chronic Total Occlusion Intervention) score (42), the RECHARGE (REgistry of Crossboss and Hybrid Procedures in FrAnce, the NetheRlands, BelGium and UnitEd Kingdom) registry score (43), the CL-score (Clinical and Lesion related score) (44), EuroCTO/CASTLE score (CABG history, Age, Stump anatomy, Tortuosity degree, Length of occlusion, Extent of calcification) (45), and the ORA (ostial location, collateral filling of Rentrop <2, age over 75) score (46). Ellis at al. used a novel approach for developing a scoring system for predicting CTO PCI technical success by stratifying lesions according to proximal cap ambiguity. The Ellis-score is currently the only one that also takis into account on operators' experience with CTO PCI (47). One study showed that various scores had similar predictive capacity for technical success and that they performed better in antegrade-only cases (48).

In general, CTO PCI should be performed when the anticipated benefits (which depend on the patient's baseline clinical condition and the likelihood of success) exceed the potential shortand long-term risks (Figure 1) $(1,49)$. 


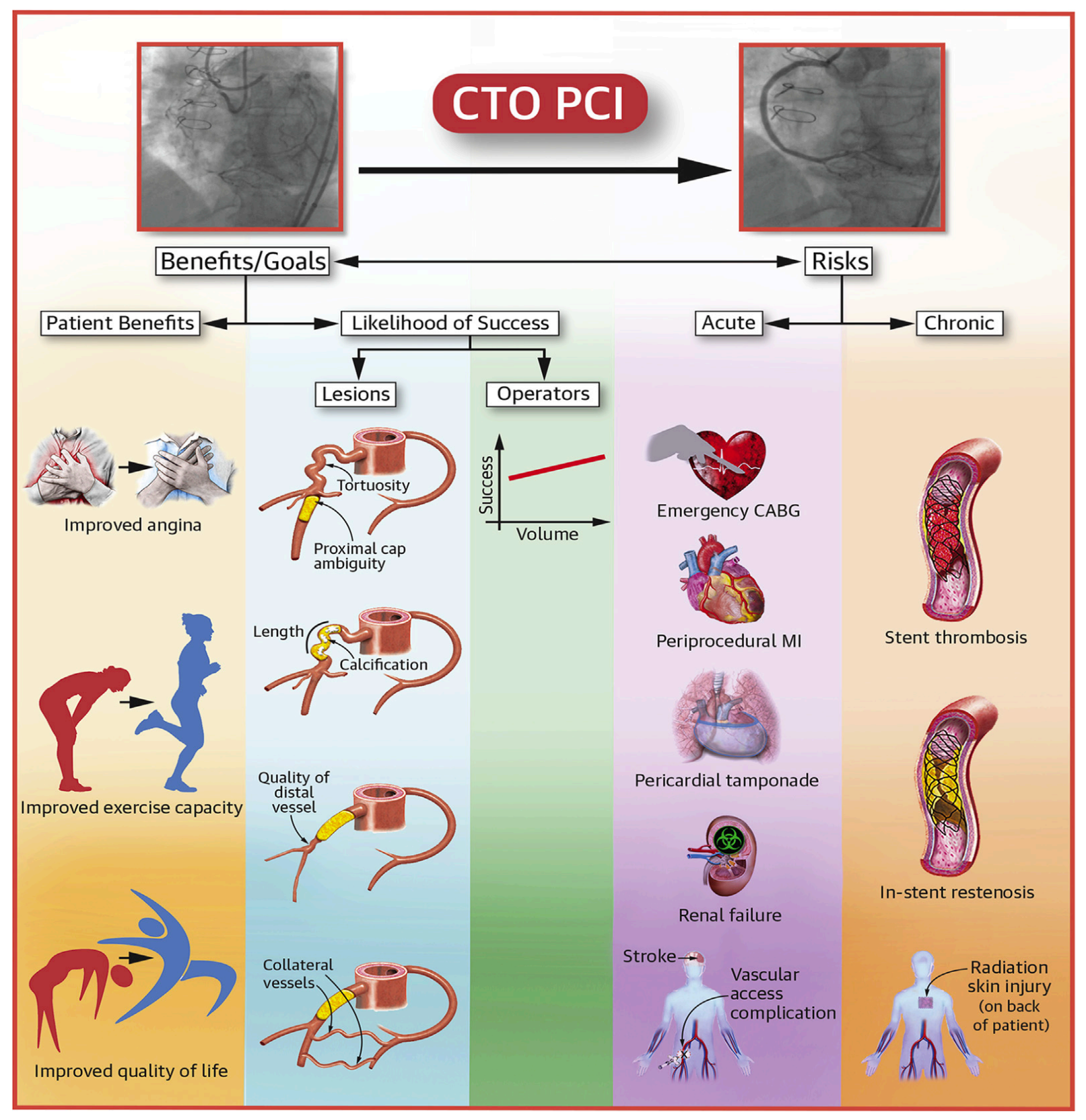

Figure 1 Overview of the Potential Risks and Benefits of CTO PCI

Parameters that can help determine the risks and benefits of chronic total occlusion percutaneous coronary intervention.

CABG, coronary artery bypass grafting; CTO, chronic total occlusion; MI, myocardial infarction; PCI, percutaneous coronary intervention.

Reproduced from reference (49). 


\section{The Hybrid Approach}

The hybrid approach to chronic total occlusion (CTO) percutaneous coronary intervention (PCI) (Figure 2) advocates dual coronary injection, careful and structured review of the angiogram, and flexibility (50). Use of all crossing strategies (Figure 3 [antegrade wire escalation (51), antegrade dissection reentry (52-55) and the retrograde approach (56-59)]) is encouraged (50), with initial and subsequent choices influenced by the CTO anatomic characteristics and the outcomes of the originally selected approach $(29,30,34,50,60-64)$.

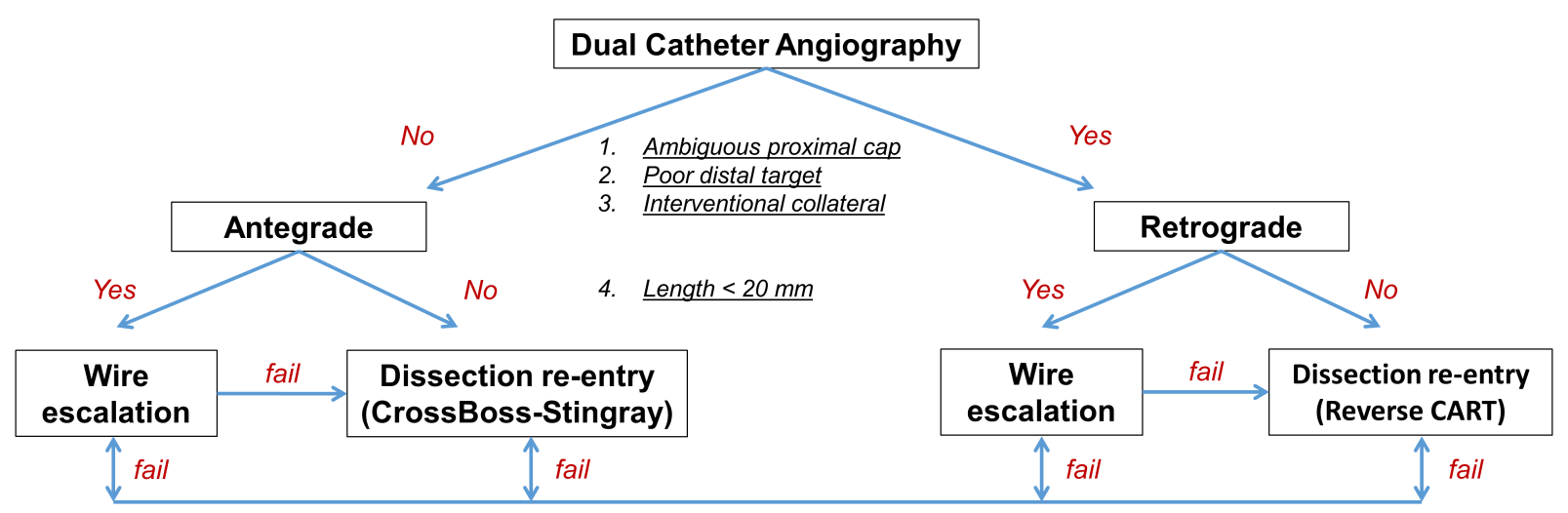

Figure 2 Hybrid algorithm for CTO PCI.

Dual angiography is performed and 4 parameters are assessed: based on them the initial crossing strategy is selected, followed by early change in case of failure to achieve progress with any other strategy.

CART: controlled antegrade and retrograde subintimal tracking.

Reproduced from reference (49).

\section{Dual catheter angiography}

The first and one of the most important steps of CTO PCI is to perform dual catheter angiography (bilateral angiography or dual coronary injection). Dual injection provides the most appropriate visualization of the proximal, distal portion of the target vessel and the collateral circulation, optimizing the selection of the most suitable initial crossing strategy. Dual injection can also assist in clarifying the current location of the guidewire(s) during crossing attempts, however it may increase the contrast utilization throughout CTO PCI (microcatheter tip injections may replace it). Based upon the diagnostic angiography, pre-procedural meticulous review should be done for at least 10 to 15 minutes focusing on four key anatomic parameters ('the anatomy 
dictates' (28)): (a) proximal cap; (b) lesion length; (c) quality of the distal vessel; and (d) the presence of collaterals amenable for retrograde approach ('interventional collaterals') (1). Dual angiography optimally starts with donor vessel injection followed by injection of the occluded vessel 2 to 3 seconds later (or even triple injections in prior CABG patients), without magnification of the image or panning, using long acquisitions or even various views. Microcatheter tip injections can facilitate distal visualization if only ipsilateral epicardial collateral connection presents as can provide more optimal view than dual angiography.

\section{Antegrade Wiring}

Antegrade wire escalation (AWE) indicates the use of guidewires of increasing stiffness to cross a CTO. This technique is the most efficient in lesions with shorter occlusion length $(<20 \mathrm{~mm})$, less tortuous vessel segments, and in occlusions with microchannels. Antegrade wire escalation technique is the most basic and widely used CTO PCI crossing approach, hence familiarity and confidence with antegrade wire escalation serves as the foundation of all other advanced CTO PCI techniques (65). In current practice AWE has four key steps: (a) approaching the CTO; (b) crossing the proximal cap; (c) navigation within the occluded segment; and (d) distal cap penetration (1).

\section{Antegrade Dissection and Re-Entry}

Antegrade dissection and re-entry are usually applied for long lesions that are approached in antegrade fashion. The subintimal space should be approached by creating a proximal dissection with advancing a "knuckle" formed at the tip of a polymer jacketed guidewire or by using CrossBoss microcatheter. Knuckle wiring minimizes the risk for perforation and also allows atraumatic subintimal crossing following the course of the vessel. The CrossBoss system is mostly recommended for in-stent CTOs due to safety purposes (preventing inadvertent wiring outside the stent struts) and cost effectiveness (66). Re-entry should be performed with the Stingray system $(1,67)$.

\section{Retrograde}

The retrograde approach can be used upfront (primary) or after failed antegrade attempt. It has four key technical steps including (a) advancement of a guidewire and microcatheter through a collateral vessel or a bypass graft distal to the occlusion, (b) crossing the occlusion, (c) wire externalization and (d) balloon angioplasty with stent implantation. Upfront retrograde crossing in 
CTOs are commonly used with proximal cap ambiguity, poor distal target, bifurcation at distal cap as well as after failure of antegrade crossing. In case of short lesions $(<20 \mathrm{~mm})$ retrograde true lumen puncture is recommended, whereas longer lesions ( $\geq 20 \mathrm{~mm})$ should be approached with the reverse controlled antegrade and retrograde subintimal tracking (reverse CART) technique (1).
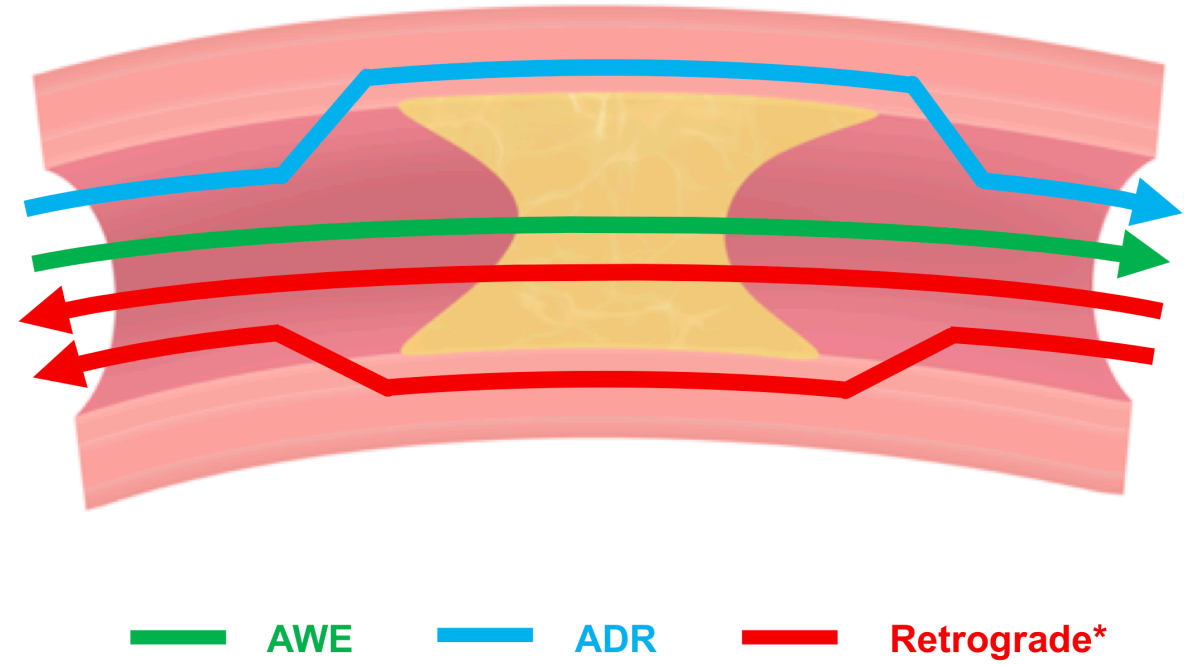

Figure 3 Summary of major crossing techniques in CTO PCI.

The four key crossing techniques in CTO PCI practice (* Retrograde indicates both retrograde wire escalation and retrograde dissection re-entry techniques).

ADR, antegrade dissection and re-entry; AWE, antegrade wire escalation.

\section{Alteration of crossing strategies}

Switching between different CTO PCI techniques is considered as the 'heart' of the hybrid algorithm. If one technique fails, another approach should be attempted. The general concept is to spend no more than 5-10 minutes in a stagnant state that may increases the risk for procedural failure due to excessive utilization of limited resources such as radiation, contrast, or time. Minor (wire tip re-shaping, change of guidewire with different crossing features), or major (change from an antegrade to a retrograde approach or vice versa) technical adjustments should be made throughout CTO PCI avoiding the stationary state, hence becoming a hybrid operator requires high level of expertise and comfortability with all CTO crossing strategies and devices (1). 
(i) We sought to examine a contemporary, multicenter CTO PCI registry to determine the techniques and outcomes of CTO PCI.

(ii) Our goal was to validate the hybrid algorithm in a diverse group of patients and operators in two continents.

(iii) We aimed to identify areas in need for improvement in the field of CTO PCI.

\section{MATERIAL AND METHODS}

We analyzed the clinical, angiographic, and procedural characteristics of 3,122 CTO PCIs performed in 3,055 patients enrolled in the PROGRESS-CTO (Prospective Global Registry for the Study of Chronic Total Occlusion Intervention, NCT02061436) registry between January 2012 and November 2017 at eighteen US, one European, and one Russian centers. The study was approved by the institutional review board (IRB) of each center.

\section{Definitions}

Coronary CTOs were defined as coronary lesions with Thrombolysis In Myocardial Infarction (TIMI) grade 0 flow of at least 3 months duration. Estimation of the duration of occlusion was clinical, based on the first onset of angina, prior history of myocardial infarction in the target vessel territory, or comparison with a prior angiogram. Calcification was assessed by angiography as mild (spots), moderate (involving $\leq 50 \%$ of the reference lesion diameter) and severe (involving $>50 \%$ of the reference lesion diameter). Moderate proximal vessel tortuosity was defined as the presence of at least 2 bends $>70^{\circ}$ or 1 bend $>90^{\circ}$ and severe tortuosity as 2 bends $>90^{\circ}$ or 1 bend $>120^{\circ}$ in the CTO vessel. Blunt or no stump was defined as lack of tapering or lack of a funnel shape at the proximal cap. Interventional collaterals were defined as collaterals considered amenable to crossing by a guidewire and a microcatheter by the operator. A procedure was defined as "retrograde" if an attempt was made to cross the lesion through a collateral vessel or bypass graft supplying the target vessel distal to the lesion; if not, the procedure was classified as "antegrade-only". Antegrade dissection/re-entry was defined as antegrade PCI during which a guidewire was intentionally introduced into the subintimal space proximal to the lesion, or re-entry into the distal true lumen was attempted following intentional or inadvertent subintimal guidewire crossing. 
Technical success was defined as successful CTO revascularization with achievement of $<30 \%$ residual diameter stenosis within the treated segment and restoration of TIMI grade 3 antegrade flow. Procedural success was defined as the achievement of technical success without any in-hospital complications. In-hospital major adverse cardiac events (MACE) included any of the following adverse events prior to hospital discharge: death, myocardial infarction, recurrent symptoms requiring urgent repeat target vessel revascularization with PCI or coronary artery bypass graft surgery $(\mathrm{CABG})$, tamponade requiring either pericardiocentesis or surgery, and stroke. Myocardial infarction (MI) was defined using the Third Universal Definition of Myocardial Infarction (type 4a MI) (68). Major bleeding was defined as bleeding causing reduction in hemoglobin $>3 \mathrm{~g} / \mathrm{dl}$ or bleeding requiring transfusion or surgical intervention. The J-CTO score was calculated as described by Morino et al (69), the PROGRESS-CTO score as described by Christopoulos et al (42), and the PROGRESS-CTO Complications score as described by Danek et al (70).

\section{Statistical Analysis}

Categorical variables were expressed as percentages and were compared using Pearson's chi-square test or Fisher's exact test. Continuous variables were presented as mean \pm standard deviation or median [interquartile range, IQR] unless otherwise specified and were compared using the t-test and 1-way analysis of variance (ANOVA) for normally distributed variables; the Wilcoxon rank-sum test, and the Kruskal-Wallis test were applied for non-parametric continuous variables, as appropriate. Multivariable logistic regression with stepwise backward elimination was performed to examine the independent association between annual CTO PCI volume and procedural outcomes (procedural success and in-hospital MACE). Variables with univariable association in the present study $(\mathrm{p}<0.05)$ were entered into the model, as well as variables that has been previously linked with procedural outcomes of CTO PCI: such variables included age, smoking, peripheral arterial disease, chronic lung disease, history of MI, stroke, PCI or CABG, left ventricular ejection fraction, CTO target vessel, multiple CTO vessel treated during the same procedure, and CTO PCI only. All statistical analyses were performed with JMP 13.0 (SAS Institute, Cary, North Carolina). A two-sided p value of 0.05 was considered statistically significant.

\section{RESULTS}




\section{Clinical characteristics}

The baseline clinical features of the study population are summarized in Table 1. As compared with patients in whom CTO PCI failed, patient in whom CTO PCI was successful were younger and less likely to be men, and to have hypertension. They were also less likely to have had a myocardial infarction, congestive heart failure, prior coronary artery bypass graft surgery, and prior PCI along with higher left ventricular ejection fraction. Most patients (89\%) were symptomatic having at least Class 2 Canadian Cardiovascular Society (CCS) Angina Classification level (CCS 2: 25\%; CCS 3: 54\%; CCS 4: 10\%), and mostly had stable (64\%) or unstable (18\%) angina.

Table 1. Clinical characteristics of the study population classified according to technical success.

\begin{tabular}{|c|c|c|c|c|}
\hline Clinical characteristics & $\begin{array}{c}\text { Overall } \\
(n=3055)\end{array}$ & $\begin{array}{c}\text { Technical success } \\
\qquad(\mathrm{n}=2657)\end{array}$ & $\begin{array}{l}\text { Technical failure } \\
\qquad(\mathrm{n}=398)\end{array}$ & $\begin{array}{c}\mathbf{p} \\
\text { value }\end{array}$ \\
\hline Age (years) * & $64.80 \pm 10.09$ & $64.6 \pm 10.15$ & $66.01 \pm 9.63$ & 0.0141 \\
\hline Male gender & $85.25 \%$ & $84.69 \%$ & $88.95 \%$ & 0.0378 \\
\hline $\operatorname{BMI}\left(\mathrm{kg} / \mathrm{m}^{2}\right) *$ & $30.60 \pm 6.14$ & $30.50 \pm 6.15$ & $31.20 \pm 6.02$ & 0.0666 \\
\hline Smoking (current) & $26.01 \%$ & $25.37 \%$ & $30.27 \%$ & 0.0561 \\
\hline Diabetes & $43.02 \%$ & $43.53 \%$ & $39.65 \%$ & 0.1758 \\
\hline Dyslipidemia & $92.20 \%$ & $92.11 \%$ & $92.75 \%$ & 0.6781 \\
\hline Hypertension & $90.26 \%$ & $89.61 \%$ & $94.49 \%$ & 0.0044 \\
\hline Family history of CAD & $33.35 \%$ & $33.44 \%$ & $32.80 \%$ & 0.8423 \\
\hline CCS Angina Classification & & & & 0.4771 \\
\hline Class $\leq 1$ & $11.44 \%$ & $11.64 \%$ & $10.15 \%$ & \\
\hline Class $2 \leq$ & $88.56 \%$ & $88.36 \%$ & $89.85 \%$ & \\
\hline Myocardial viability performed & $24.99 \%$ & $24.28 \%$ & $29.32 \%$ & 0.0783 \\
\hline Prior MI & $46.00 \%$ & $44.82 \%$ & $53.75 \%$ & 0.0023 \\
\hline Heart failure & $30.56 \%$ & $29.71 \%$ & $36.25 \%$ & 0.0159 \\
\hline Prior valve surgery or procedure & $3.17 \%$ & $3.06 \%$ & $3.89 \%$ & 0.4210 \\
\hline Prior PCI & $65.29 \%$ & $64.49 \%$ & $70.62 \%$ & 0.0180 \\
\hline Prior CABG & $32.49 \%$ & $31.28 \%$ & $40.68 \%$ & 0.0003 \\
\hline
\end{tabular}




\begin{tabular}{lcccc} 
Baseline creatinine $(\mathrm{mg} / \mathrm{dL}) \dagger$ & $1.01(0.89,1.22)$ & $1.01(0.89,1.21)$ & $1.07(0.90,1.27)$ & 0.1301 \\
Currently on dialysis & $2.67 \%$ & $2.50 \%$ & $3.80 \%$ & 0.1633 \\
Prior CVD & $11.70 \%$ & $11.51 \%$ & $12.90 \%$ & 0.4567 \\
Prior PAD & $15.02 \%$ & $14.53 \%$ & $18.29 \%$ & 0.0709 \\
Chronic lung disease & $14.20 \%$ & $13.80 \%$ & $16.81 \%$ & 0.1386 \\
Left ventricular EF $(\%) \dagger$ & $54(42,60)$ & $55(44,60)$ & $50(40,60)$ & 0.0357 \\
\hline
\end{tabular}

$*$ mean \pm standard deviation; $\uparrow$ median (interquartile range)

BMI, body mass index; CABG, coronary artery bypass graft; CAD, coronary artery disease; CVD, cerebrovascular disease; EF, ejection fraction; MI, myocardial infarction; PCI, percutaneous coronary intervention; PVD, peripheral arterial disease.

\section{Angiographic characteristics}

The angiographic characteristics of the study lesions are presented in Table 2. The CTO target lesions were located in the right coronary artery (55\%), left anterior descending artery (24\%) and left circumflex artery (20\%). Failed CTO PCI was associated with longer lesion length ( $37.8 \pm 24.0 \mathrm{~mm}$ vs. $33.4 \pm 24.1 \mathrm{~mm}, \mathrm{p}=0.0030$ ), proximal cap ambiguity ( $54 \%$ vs. $32 \%, \mathrm{p}<0.0001)$, moderate to severe calcification ( $73 \%$ vs. $52 \%, \mathrm{p}<0.0001)$ and tortuosity $(45 \%$ vs. $33 \%$, $\mathrm{p}<0.0001)$, or previously failed recanalization attempt ( $27 \%$ vs. $19 \%, \mathrm{p}=0.0005)$. Failed CTO PCI cases also had higher J-CTO score (3.07 \pm 1.13 vs. $2.34 \pm 1.29$, p<0.0001), PROGRESS-CTO score (1.77 \pm 1.13 vs. $1.25 \pm 1.01, \mathrm{p}<0.0001)$, and PROGRESS-CTO complications score $(3.54 \pm 1.97$ vs. $3.00 \pm 1.91, \mathrm{p}<0.0001)$.

Table 2. Angiographic characteristics of study lesions, classified according to technical success.

\begin{tabular}{ccccc} 
Angiographic characteristics & $\begin{array}{c}\text { Overall } \\
\mathbf{( 3 1 2 2})\end{array}$ & $\begin{array}{c}\text { Technical } \\
\text { success }(\mathbf{n = 2 7 1 1})\end{array}$ & $\begin{array}{c}\text { Technical } \\
\text { failure (n=411) }\end{array}$ & p value \\
\hline Target vessel & & & & 0.0640 \\
RCA & $55.22 \%$ & $54.93 \%$ & $57.14 \%$ & \\
LAD & $23.81 \%$ & $24.57 \%$ & $18.80 \%$ & \\
LCX & $19.91 \%$ & $19.47 \%$ & $22.81 \%$ \\
Other & $1.06 \%$ & $1.03 \%$ & $1.25 \%$
\end{tabular}




\begin{tabular}{lcccc} 
CTO length $(\mathrm{mm})^{*}$ & $33.99 \pm 24.16$ & $33.43 \pm 24.14$ & $37.80 \pm 23.99$ & 0.0030 \\
Vessel diameter $(\mathrm{mm}) *$ & $2.85 \pm 0.51$ & $2.86 \pm 0.51$ & $2.81 \pm 0.47$ & 0.1383 \\
Proximal cap ambiguity & $35.06 \%$ & $31.98 \%$ & $53.97 \%$ & $<0.0001$ \\
Side branch at proximal cap & $49.91 \%$ & $47.56 \%$ & $64.14 \%$ & $<0.0001$ \\
Blunt stump/no stump & $53.69 \%$ & $50.61 \%$ & $72.55 \%$ & $<0.0001$ \\
Interventional collaterals & $56.72 \%$ & $58.80 \%$ & $44.19 \%$ & $<0.0001$ \\
Moderate/severe calcification & $54.23 \%$ & $52.30 \%$ & $67.02 \%$ & $<0.0001$ \\
Moderate/severe tortuosity & $34.96 \%$ & $33.43 \%$ & $45.21 \%$ & $<0.0001$ \\
In-stent restenosis & $16.61 \%$ & $16.13 \%$ & $19.68 \%$ & 0.0878 \\
Previously failed CTO PCI & $20.20 \%$ & $19.21 \%$ & $26.70 \%$ & 0.0005 \\
J-CTO score * & $2.43 \pm 1.30$ & $2.34 \pm 1.29$ & $3.07 \pm 1.13$ & $<0.0001$ \\
PROGRESS-CTO score * & $1.32 \pm 1.03$ & $1.25 \pm 1.01$ & $1.77 \pm 1.01$ & $<0.0001$ \\
PROGRESS-CTO complication score * & $3.07 \pm 1.93$ & $3.00 \pm 1.91$ & $3.54 \pm 1.97$ & $<0.0001$ \\
\hline
\end{tabular}

*mean \pm standard deviation

CTO, chronic total occlusion; J, Japan; LAD, left anterior descending artery; LCX, left circumflex artery; LM, left main segment; PCI, percutaneous coronary intervention; PROGRESS-CTO, Prospective Global Registry of Chronic Total Occlusion Interventions; RCA, right coronary artery.

\section{Procedural outcomes of the hybrid approach}

Overall technical and procedural success was $87 \%$ and $85 \%$ respectively and the inhospital major complications rate was $3.0 \%$. The baseline technical and procedural characteristics are presented in Tables 3,4 and 5. Antegrade wire escalation was the most commonly used initial approach (in 75\%), especially in lower complexity CTOs (J-CTO score: $2.28 \pm 1.29$, PROGRESS CTO score: $1.35 \pm 1.05$ ), while antegrade dissection/reentry (8\%; J-CTO score: $2.86 \pm 1.16$, PROGRESS CTO score: $1.50 \pm 1.07)$ and the retrograde approach (16\%; J-CTO score: $3.12 \pm 1.07$, PROGRESS CTO score: $1.33 \pm 0.96)$ were used in more complex lesions $(\mathrm{p}<0.0001)$. The initial approach was successful in 55\% of the cases, while $41 \%$ of the cases underwent further attempts that were technically successful in 79\% (Figure 4). 
Table 3. Techniques used for CTO PCI in the study patients.

\begin{tabular}{|c|c|c|c|c|}
\hline Technical characteristics & Overall (3122) & $\begin{array}{c}\text { Technical success } \\
\qquad(n=2711)\end{array}$ & $\begin{array}{l}\text { Technical failure } \\
\qquad(n=411)\end{array}$ & $p$ value \\
\hline
\end{tabular}

Crossing strategies used

$\begin{array}{lccc}\text { AWE } & 81.77 \% & 81.15 \% & 85.89 \% \\ \text { ADR } & 31.68 \% & 29.69 \% & 44.77 \% \\ \text { Retrograde } & 38.57 \% & 35.96 \% & 55.72 \% \\ \text { ins strategy } & & & \\ \text { AWE } & 75.36 \% & 75.80 \% & 72.51 \% \\ \text { ADR } & 8.39 \% & 8.67 \% & 6.57 \% \\ \text { Retrograde } & 16.24 \% & 15.53 \% & 20.92 \%\end{array}$

Final crossing strategy

AWE

$45.89 \%$

$51.95 \%$

$<0.0001$

ADR

$18.95 \%$

$20.96 \%$

$5.24 \%$

Retrograde

$23.97 \%$

$27.09 \%$

$5.49 \%$

None

$11.19 \%$

$0.00 \%$

$2.99 \%$

Balloon uncrossable lesions

$10.62 \%$

$10.21 \%$

$86.28 \%$

Balloon undilatable lesions

$11.11 \%$

$10.74 \%$

$29.37 \%$

$<0.0001$

$22.22 \%$

0.0349

Access site

Right femoral
Left femoral
Right radial
Left radial

Bifemoral approach

$78.96 \%$

$78.46 \%$

$82.24 \%$

0.0798

$54.29 \%$

$53.34 \%$

$60.58 \%$

0.0060

$32.48 \%$

$33.12 \%$

$28.22 \%$

0.0481

$18.67 \%$

$19.48 \%$

$13.38 \%$

0.0031

Biradial approach

$51.35 \%$

$50.42 \%$

$57.42 \%$

0.0082

$14.09 \%$

$14.90 \%$

$8.76 \%$

0.0009

ADR, antegrade dissection reentry; AWE, antegrade wire escalation. 


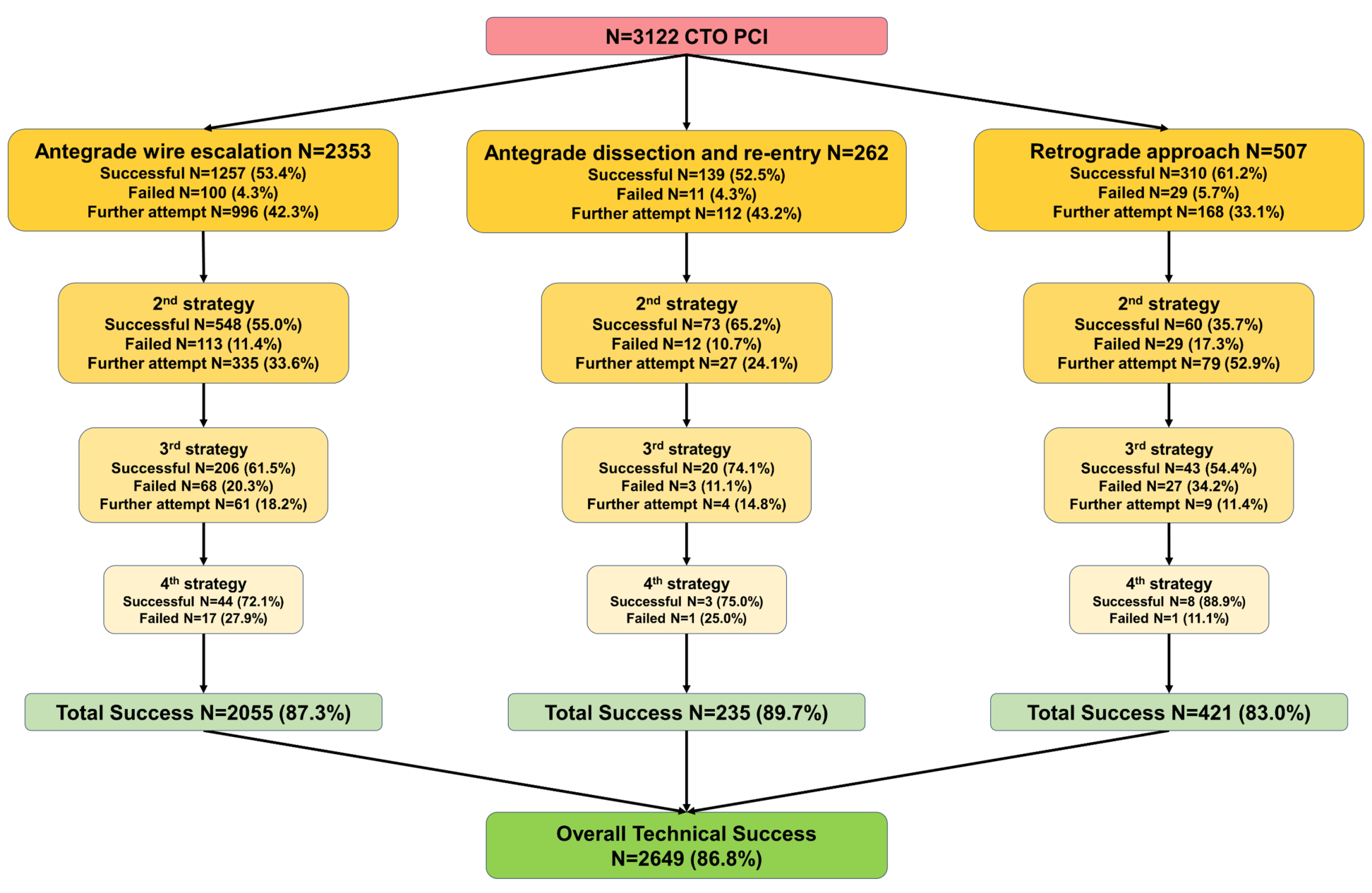

Figure 4 Application of the hybrid approach in the study patients

Sequence of CTO crossing techniques used in the study patients and associated technical success.

CTO, chronic total occlusion; PCI, percutaneous coronary intervention. 
The final successful crossing strategy was antegrade wire escalation (46\%), antegrade dissection reentry (19\%), and the retrograde approach $(24 \%)$. The success of antegrade wire escalation decreased with lesion complexity (Figure 5), as classified with the J-CTO score (easy [J-CTO 0]: 88\%; intermediate [J-CTO 1]: 72\%; difficult [J-CTO 2]: $51 \%$ and very difficult [JCTO $\geq 3$ ]: $32 \%$ to $17 \%$; $<<0.0001)$, and the PROGRESS-CTO score $(55 \%, 43 \%, 42 \%, 39 \%$ and $43 \%$, respectively for scores of $0,1,2,3$, and 4 ; $p<0.0001$ ).

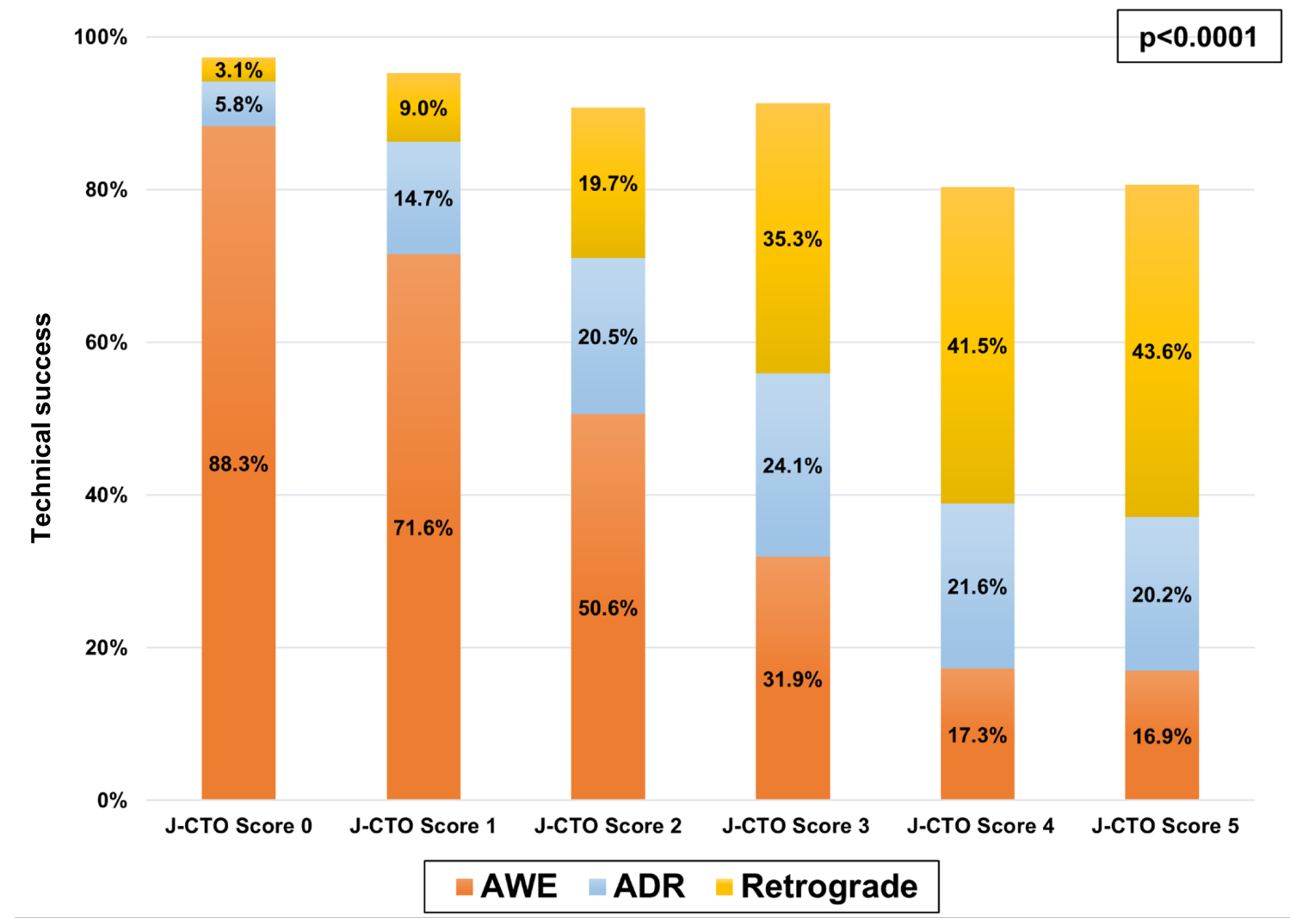

Figure 5 Technical success and crossing strategy utilization according to the J-CTO score.

Impact of CTO lesion complexity on technical success and use of various crossing strategies.

ADR, antegrade dissection reentry; AWE, antegrade wire escalation; CTO, chronic total occlusion; J, Japan.

The retrograde approach was more commonly required in complex lesions, as classified by the J-CTO score $(3 \%, 9 \%, 20 \%, 35 \%$ to $44 \%$, respectively for J-CTO scores of $0,1,2$, and $\geq 3$, $\mathrm{p}<0.0001$ ), but less frequently in lesions as classified according to the PROGRESS-CTO score $(23 \%, 27 \%, 23 \%, 15 \%, 6 \%, \mathrm{p}<0.0001)$ (Figure 6). 


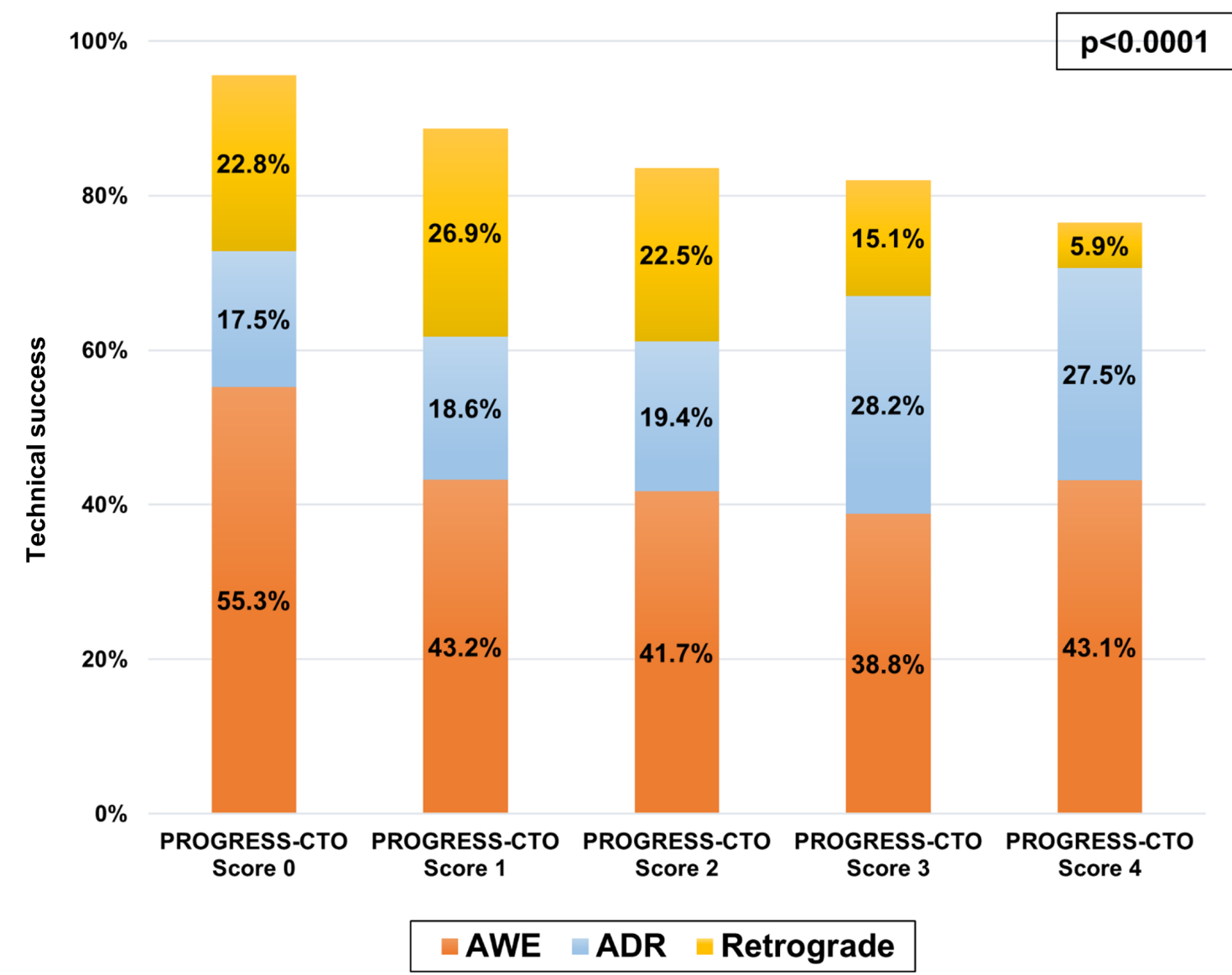

Figure 6 Successful crossing strategy utilization according to the PROGRESS-CTO score.

The impact of retrograde technique utiliztion is less potent with increasing CTO lesion complexity.

ADR, antegrade dissection reentry; AWE, antegrade wire escalation; CTO, chronic total occlusion;

PROGRESS-CTO, PROspective Global REgiStry for the Study of Chronic Total Occlusion Intervention.

Dual injection was used in $70 \%$ of all cases, and was more frequent in failed interventions (76\% vs. $70 \%, \mathrm{p}=0.026)$ and in complex lesions with high $\mathrm{J}-\mathrm{CTO}$ scores $(48 \%$ vs. $78 \%, \mathrm{p}<0.0001)$. Radial access was used in $37 \%$ overall, with biradial approach in 14\%, and in combination with femoral approach in $20 \%$ of the cases. Use of radial access was lower with increasing lesion complexity (easy: $50 \%$, intermediate: $39 \%$, difficult: $36 \%$, very difficult: $38 \%, \mathrm{p}=0.003$ ), whereas the frequency of femoral $(63 \%, 78 \%, 83 \%, 84 \%, \mathrm{p}<0.0001)$ and bifemoral approach $(28 \%, 43 \%$, $51 \%, 57 \%, \mathrm{p}<0.0001)$ increased with increasing lesion complexity. Median contrast volume, air kerma radiation dose, procedure and fluoroscopy time were 270 (200-360) ml, 2.9 (1.7-4.7) Gray, 123 (81-188) and 47.0 (28.6-77.0) minutes, respectively, and were higher in more complex lesions. 
Less complex lesions required fewer stents $(\mathrm{p}<0.0001)$, however the frequency of non-CTO PCI was higher in those groups, and decreased with increasing lesion complexity $(\mathrm{p}=0.08)$.

Table 4. Procedural characteristics, classified according to PCI outcomes.

\begin{tabular}{lcccc} 
Procedural outcomes & $\begin{array}{c}\text { Overall } \\
(\mathbf{n = 3 0 5 5})\end{array}$ & $\begin{array}{c}\text { Technical success } \\
(\mathbf{n = 2 6 5 7})\end{array}$ & $\begin{array}{c}\text { Technical failure } \\
(\mathbf{n = 3 9 8})\end{array}$ & p value \\
\hline Dual injection & $70.41 \%$ & $69.57 \%$ & $75.82 \%$ & 0.0260 \\
Radial access $\ddagger$ & $37.06 \%$ & $37.70 \%$ & $32.85 \%$ & 0.0577 \\
Femoral access & $81.90 \%$ & $81.37 \%$ & $85.40 \%$ & 0.0480 \\
Procedure time $(\mathrm{min}) *$ & $123(81,188)$ & $121(80,184)$ & $140(85,224)$ & $<0.0003$ \\
Contrast volume $(\mathrm{mL}) *$ & $270(200,360)$ & $260(200,350)$ & $300(220,400)$ & $<0.0001$ \\
Fluoroscopy time $(\mathrm{min}) *$ & $47.0(28.6,77.0)$ & $45.0(27.3,73.7)$ & $66.0(39.0,93.6)$ & $<0.0001$ \\
Patient AK dose $(\mathrm{Gray}) *$ & $2.9(1.7,4.7)$ & $2.8(1.6,4.5)$ & $3.9(2.4,6.0)$ & $<0.0001$ \\
Number of stents $\dagger \S$ & $2.4 \pm 1.1$ & $2.4 \pm 1.1$ & $2.7 \pm 1.6$ & 0.5559 \\
Stent length $(\mathrm{mm}) \dagger \S$ & $71.8 \pm 36.4$ & $71.7 \pm 36.3$ & $78.6 \pm 47.6$ & 0.6599 \\
Non-CTO lesion PCI & $28.20 \%$ & $28.39 \%$ & $26.80 \%$ & 0.5611 \\
In-hospital MACE & $3.04 \%$ & $2.37 \%$ & $7.54 \%$ & $<0.0001$ \\
\hline
\end{tabular}

* median (interquartile range)

$\dagger$ mean \pm standard deviation

\$ Radial access indicates any radial access site use in CTO PCI; including biradial and combined radial-femoral approaches

$\S$ In successful cases stents were implanted in $97.10 \%$ vs. in failed procedures in $4.89 \%$ (related to perforation, investment procedure, donor vessel dissection, or stenting but $3 \geq$ Thrombolysis In Myocardial Infarction flow grade), $\mathrm{p}<0.0001$.

AK, air kerma; PCI, percutaneous coronary intervention; MACE: major adverse cardiac event. 
Table 5. Procedural characteristics, classified according to PCI outcomes and lesion complexity (J-CTO score).

\begin{tabular}{lccccc} 
Procedural outcomes & Easy (0) & $\begin{array}{c}\text { Intermediate } \\
(\mathbf{1})\end{array}$ & Difficult (2) & $\begin{array}{c}\text { Very difficult } \\
(\mathbf{3})\end{array}$ & $\begin{array}{c}\text { p for } \\
\text { trend }\end{array}$ \\
\hline Dual injection & $47.59 \%$ & $64.19 \%$ & $68.70 \%$ & $77.89 \%$ & $<0.0001$ \\
Radial access $\ddagger$ & $49.59 \%$ & $39.09 \%$ & $35.83 \%$ & $38.17 \%$ & 0.0030 \\
Femoral access & $63.27 \%$ & $78.17 \%$ & $82.65 \%$ & $84.09 \%$ & $<0.0001$ \\
Procedure time $(\mathrm{min}) *$ & $77(46,117)$ & $92(58,136)$ & $115(73,172)$ & $152(102,217)$ & $<0.0001$ \\
Contrast volume $(\mathrm{mL}) *$ & $220(160,300)$ & $250(190,340)$ & $260(200,350)$ & $280(202,385)$ & $<0.0001$ \\
Fluoroscopy time $(\mathrm{min}) *$ & $27(18,39)$ & $33(19,54)$ & $42(27,66)$ & $63(39,93)$ & $<0.0001$ \\
Patient AK dose $(\mathrm{Gray}) *$ & $1.8(0.9,3.3)$ & $2.1(1.2,3.5)$ & $2.5(1.4,4.4)$ & $3.5(2.1,5.2)$ & $<0.0001$ \\
Number of stents $\dagger \S$ & $1.8 \pm 0.9$ & $2.0 \pm 1.0$ & $2.3 \pm 1.1$ & $2.8 \pm 1.2$ & $<0.0001$ \\
Stent length (mm) $\dagger \S$ & $48.0 \pm 25.2$ & $57.6 \pm 31.1$ & $66.5 \pm 33.5$ & $85.5 \pm 36.3$ & $<0.0001$ \\
Non-CTO lesion PCI & $32.75 \%$ & $32.00 \%$ & $29.19 \%$ & $26.37 \%$ & 0.0786 \\
In-hospital MACE & $1.36 \%$ & $1.41 \%$ & $3.01 \%$ & $3.11 \%$ & 0.0119 \\
Technical success & $96.90 \%$ & $94.84 \%$ & $89.14 \%$ & $81.26 \%$ & $<0.0001$ \\
\hline
\end{tabular}

* median (interquartile range)

$\dagger$ mean \pm standard deviation

$\$$ Radial access indicates any radial access site use in CTO PCI; including biradial and combined radial-femoral approaches

AK, air kerma; PCI, percutaneous coronary intervention; MACE: major adverse cardiac event.

The procedural success and annual CTO PCI volume in the participating sites are shown in Figure 7. 


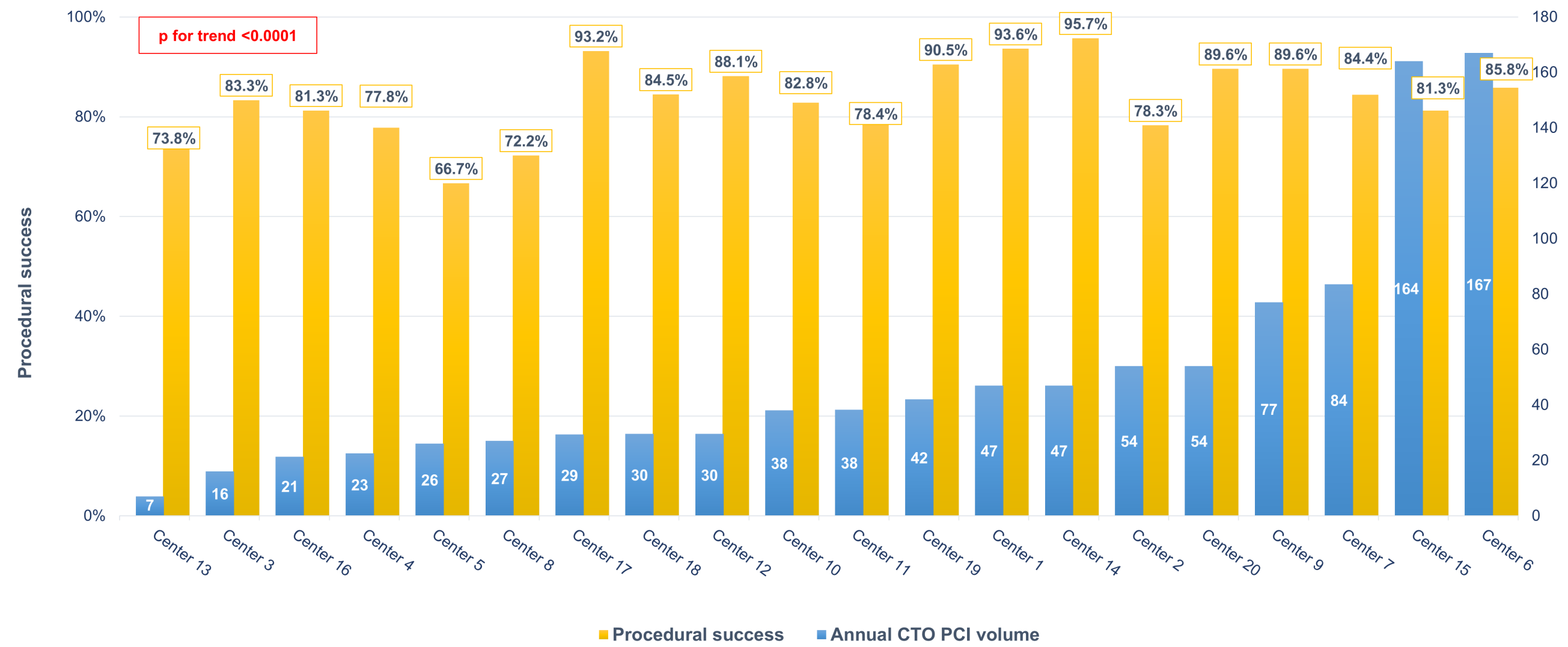

Figure 7 Procedural success rate and annual CTO PCI volume in the participating centers.

Procedural success rate significantly differed in the participating sites ( $\mathrm{p}$ for trend $<0.0001$ ) with increasing annual CTO PCI volume.

CTO, chronic total occlusion; PCI, percutaneous coronary intervention. 
Higher median annually performed CTO PCI per center was associated with higher procedural success on both univariable and multivariable analysis (Figure 8) but not in-hospital MACE.

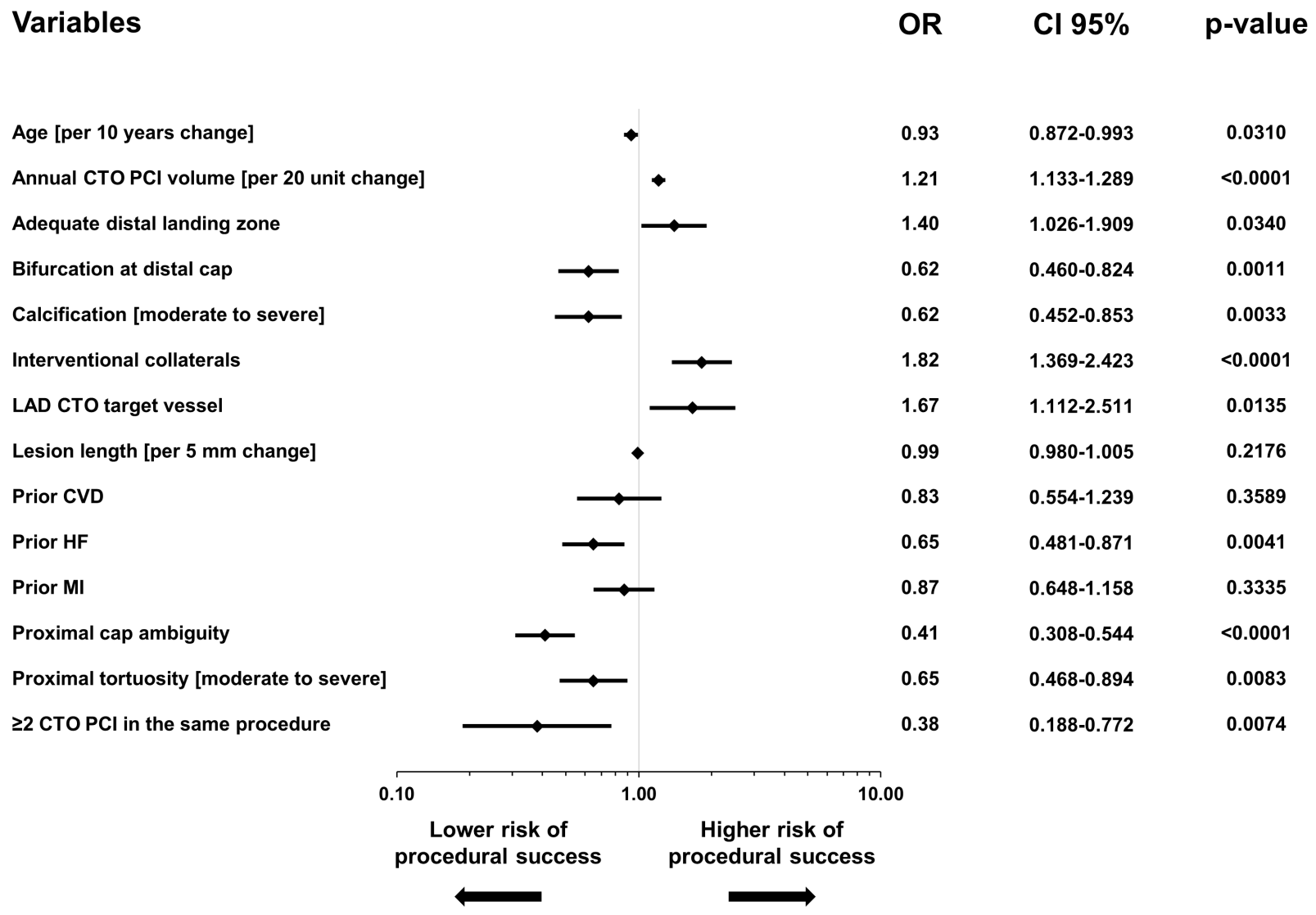

Figure 8 Baseline clinical and angiographic characteristics and procedural success.

Multivariable analysis of parameters associated with procedural success.

CI, confidence interval, CVD, cerebrovascular disease; CTO, chronic total occlusion; LAD, left anterior descending; HF, heart failure; MI, myocardial infarction; OR, odds ratio, PCI, percutaneous coronary intervention.

The incidence of in-hospital MACE was 3.04\% [death $(0.85 \%)$, acute myocardial infarction $(1.08 \%)$, stroke $(0.26 \%)$, emergency CABG $(0.16 \%)$, urgent re-PCI $(0.36 \%)$, and pericardial tamponade $(0.85 \%)]$, and increased with increasing lesion complexity (Table 5). The prevalence of in-hospital MACE (major adverse cardiac event) were higher in failed procedures $(7.54 \%$ vs. $2.37 \%, \mathrm{p}<0.0001)$ (Table 6) and with more complex crossing techniques: antegrade 
wire escalation, antegrade dissection reentry or retrograde crossing (1.09\% vs. $2.96 \%$ vs. $5.61 \%$, $\mathrm{p}<0.0001)$. Use of the retrograde approach was associated with higher incidence of complications, as shown in Figure 9. Median length of hospital stay was significantly higher in patients with vs. without in-hospital MACE (6 [2-9] days vs. 1 [1-2] days), p<0.0001).

Table 6. Procedural complications in the study patients.

\begin{tabular}{|c|c|c|c|c|}
\hline Variable & $\begin{array}{c}\text { Overall } \\
(\mathbf{n}=3055)\end{array}$ & $\begin{array}{l}\text { Technical success } \\
\qquad(n=2657)\end{array}$ & $\begin{array}{l}\text { Technical failure } \\
\qquad(\mathrm{n}=398)\end{array}$ & p value \\
\hline In-hospital MACE & $3.04 \%$ & $2.37 \%$ & $7.54 \%$ & $<0.0001$ \\
\hline Death & $0.85 \%$ & $0.68 \%$ & $2.01 \%$ & 0.0143 \\
\hline Acute MI & $1.08 \%$ & $0.79 \%$ & $3.02 \%$ & 0.0005 \\
\hline Stroke & $0.26 \%$ & $0.30 \%$ & $0.00 \%$ & 0.6072 \\
\hline Re-PCI & $0.36 \%$ & $0.38 \%$ & $0.25 \%$ & 1.0000 \\
\hline Emergency CABG & $0.16 \%$ & $0.08 \%$ & $0.75 \%$ & 0.0179 \\
\hline Pericardiocentesis & $0.85 \%$ & $0.53 \%$ & $3.02 \%$ & $<0.0001$ \\
\hline Perforation & $4.48 \%$ & $3.54 \%$ & $10.80 \%$ & $<0.0001$ \\
\hline Vascular access complication & $1.44 \%$ & $1.39 \%$ & $1.76 \%$ & 0.5674 \\
\hline Equipment loss & $0.23 \%$ & $0.19 \%$ & $0.50 \%$ & 0.2288 \\
\hline DV dissection/thrombosis & $1.15 \%$ & $1.05 \%$ & $1.76 \%$ & 0.2081 \\
\hline Bleeding & $1.18 \%$ & $1.20 \%$ & $1.01 \%$ & 1.0000 \\
\hline Aortocoronary dissection & $0.10 \%$ & $0.08 \%$ & $0.25 \%$ & 0.3422 \\
\hline Contrast induced nephropathy $*$ & $0.36 \%$ & $0.38 \%$ & $0.25 \%$ & 1.0000 \\
\hline
\end{tabular}

CABG, coronary artery bypass graft surgery; DV, donor vessel; PCI, percutaneous coronary intervention; MACE, major adverse cardiac event; MI, myocardial infarction.

* Contrast induced nephropathy is defined as a relative increase of $\geq 25 \%$ or absolute increase of $\geq 0.5 \mathrm{mg} / \mathrm{dL}$ in pre-PCI serum creatinine at $48 \mathrm{~h}$ after PCI. 
$6 \%$

$4 \%$

$2 \%$

$0 \%$
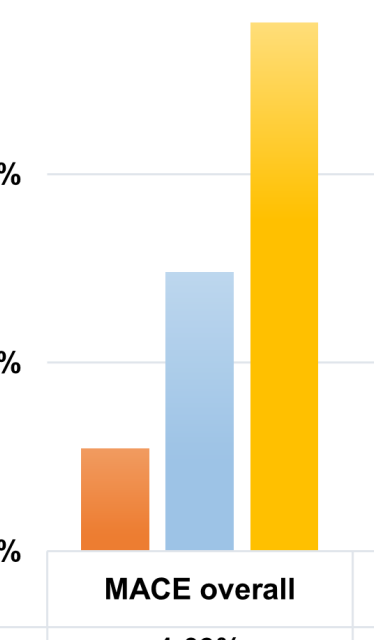

$1.09 \%$

$2.96 \%$

$5.61 \%$

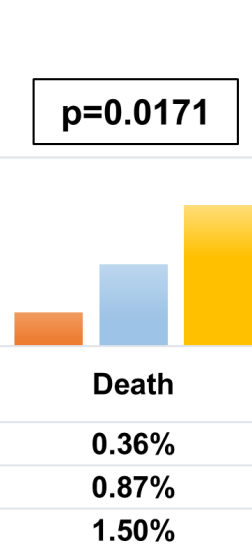

\section{$p<0.0001$}
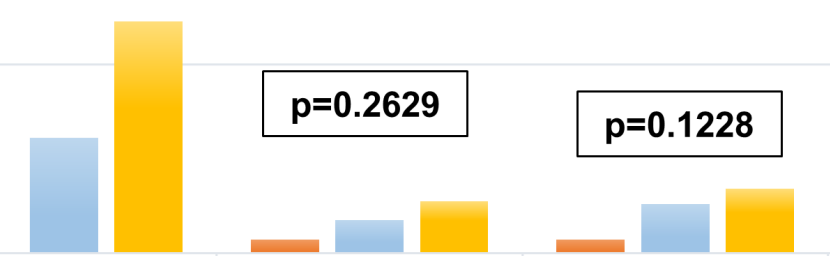

Acute MI

$0.00 \%$

$1.22 \%$

$2.46 \%$

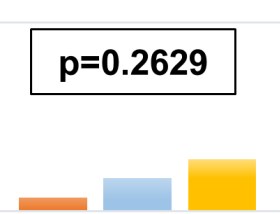

Stroke

$0.14 \%$

$0.35 \%$

$0.55 \%$

\begin{tabular}{l} 
Re-PCI \\
$0.14 \%$ \\
\hline $0.52 \%$ \\
\hline
\end{tabular}

$0.68 \%$

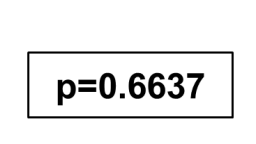

Emergency CABG

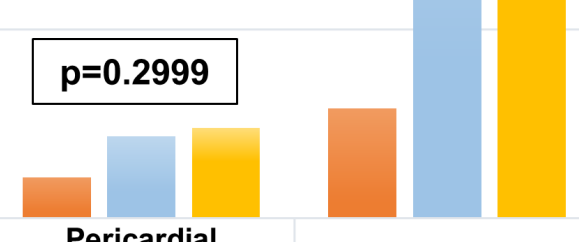

Pericardial

tamponade

$0.43 \%$

$0.87 \%$

$0.96 \%$
Perforation

$1.16 \%$

$5.22 \%$

$7.52 \%$

Figure 9 In-hospital major complications classified according to final successful crossing strategy.

Use of the retrograde approach was associated with higher overall in-hospital MACE and risk for perforation.

ADR, antegrade dissection and reentry; AWE, antegrade wire escalation; CABG, coronary artery bypass graft; MACE, major adverse cardiac event; MI,

myocardial infarction; PCI, percutaneous coronary intervention. 


\section{DISCUSSION}

To the best of our knowledge this is the largest study reported to date on CTO PCI using the hybrid approach, demonstrating high technical success rates (87\%) with acceptable major complication rate $(3.04 \%)$. These outcomes were achieved despite high lesion complexity and relatively low success of the initially selected CTO crossing strategy (55\%) (Figure 4).

Previous smaller studies have provided similarly encouraging results. In an earlier report from the PROGRESS-CTO registry from 11 US centers, technical success was $91 \%$ and inhospital MACE was 1.7\% (29). Wilson et al reported following $79 \%$ initial success rate among 1156 patients from 7 centers enrolled in the UK Hybrid CTO Registry, with 90\% final technical success rate after repeat procedures (30). The RECHARGE registry of 1253 CTO interventions performed in 1177 patients between 2014 and 2015 at 22 European centers, reported 86\% procedural success rate and $2.6 \%$ major in-hospital complication rate (34). Vo et al reported a single operator pilot-study showing rapid increase in procedural success despite the low initial CTO-PCI experience (71). At two high-volume, experienced, centers Pershad et al showed significant increase in technical $(79.4 \%$ to $95.4 \%, \mathrm{p}<0.001)$ and procedural $(77.9 \%$ to $88.3 \%)$ success rates after implementation of the hybrid algorithm, as compared with the preimplementation period (62). Furthermore, in the Hybrid Video Registry analyzed 194 video-taped live case demonstrations reporting high success rates (92.8\%), even in highly complex CTOs with acceptable procedure time and contrast volume (72).

In the present study we found that technical and procedural success remained high with reasonably low complication rates despite expansion of the registry in recent years. Antegrade wire escalation was more commonly applied as the initial crossing approach (74\%) in less complex lesions (J-CTO score: $2.24 \pm 1.24$, PROGRESS-CTO score: $1.32 \pm 0.87$ ) and was the most common final crossing strategy (in approximately half the cases). Antegrade dissection reentry and retrograde techniques were more likely to be used as initial strategy in cases with complex anatomy (J-CTO score $2.78 \pm 1.21$ and $3.32 \pm 0.98$, respectively; PROGRESS-CTO score $1.38 \pm 0.93$ and $2.00 \pm 0.89$, respectively), and were the final successful strategy in $22 \%$ and $28 \%$ of all cases.

Failure to cross with a guidewire was the most common reason for CTO PCI failure (in $86 \%$ ). In $13 \%$ the procedure failed despite successful guidewire crossing (Table 3) due to balloon undilatable lesions (3.9\%), inability to deliver stents (2.3\%), final TIMI flow $<3(1.3 \%)$, residual 
stenosis $>30 \%(1.0 \%)$, and procedure-related complications $(0.8 \%, 1$ patient with donor vessel thrombosis, 1 patient with aortocoronary dissection, and 1 procedure related death due to pericardial tamponade and subsequent cardiogenic shock). The presence of balloon uncrossable ( $29 \%$ vs. $10 \%, \mathrm{p}<0.0001)$, and undilatable lesions ( $22 \%$ vs. $11, \mathrm{p}=0.0109$ ) was higher in the failed CTO PCI group, highlighting the need for CTO PCI operators to have experience in treating these and other complex lesions, such as severe calcification and bifurcations (73-76).

As shown in prior studies higher annual CTO PCI volume was independently associated with higher success rates, reflecting the importance of center and operator experience in optimizing outcomes, even among complex lesion and patient subgroups (77). Our study confirms that annual CTO PCI volume significantly improves procedural success amongst various operators and lesion subsets (1.21 OR, CI 95\%, 1.13 to 1.29, p<0.0001) (Figure 8). Attempting 2 or more CTO PCI during the same procedure $(0.38$ OR, CI $95 \% 0.18$ to $0.77, \mathrm{p}=0.0074)$ lowers the likelihood of procedural success, that is currently not recommended due to high potential risk for compromising larger myocardial territory that may result in higher procedure-related in-hospital mortality (78).

Based upon both univariate and multivariate analysis, several anatomic parameters were found to have significant impact on decreasing procedural success (calcification, tortuosity, proximal cap ambiguity) that have been linked with CTO PCI failure in prior studies $(35,79,80)$, and also were implemented into various scores. Nevertheless, distal occlusion anatomy also determines procedural outcomes which is well represented in our study: bifurcation at distal cap decreases [0.62 OR, CI 95\% 0.46 to $0.82, \mathrm{p}=0.0011$, and conversely, appropriate distal vessel landing zone increases the likelihood of success (1.40 OR, CI 95\% 1.03 to $1.91, \mathrm{p}=0.0340)$.

Furthermore, the prevalence of prior $\mathrm{CABG}$ was $32 \%$, which is more common compared to European $(15-22 \%(30,31,34))$ or Japanese $(8-12 \%(33,81))$ registries. PCI in patients with prior bypass graft surgery is especially challenging due to multiple comorbidities, more complex coronary anatomy, and bypass graft failures requiring multiple re-interventions either in the grafts or native coronary arteries (commonly requiring CTO PCI) (82). Creative solutions, and comfortability with all available CTO PCI techniques are required in such challenging patient population (Figure 10 and 11) (83). Optimization of CTO PCI techniques, however, in post-bypass patients should be one of the major focus points of upcoming research as procedural success remains lower compared with patients without prior CABG (84). 


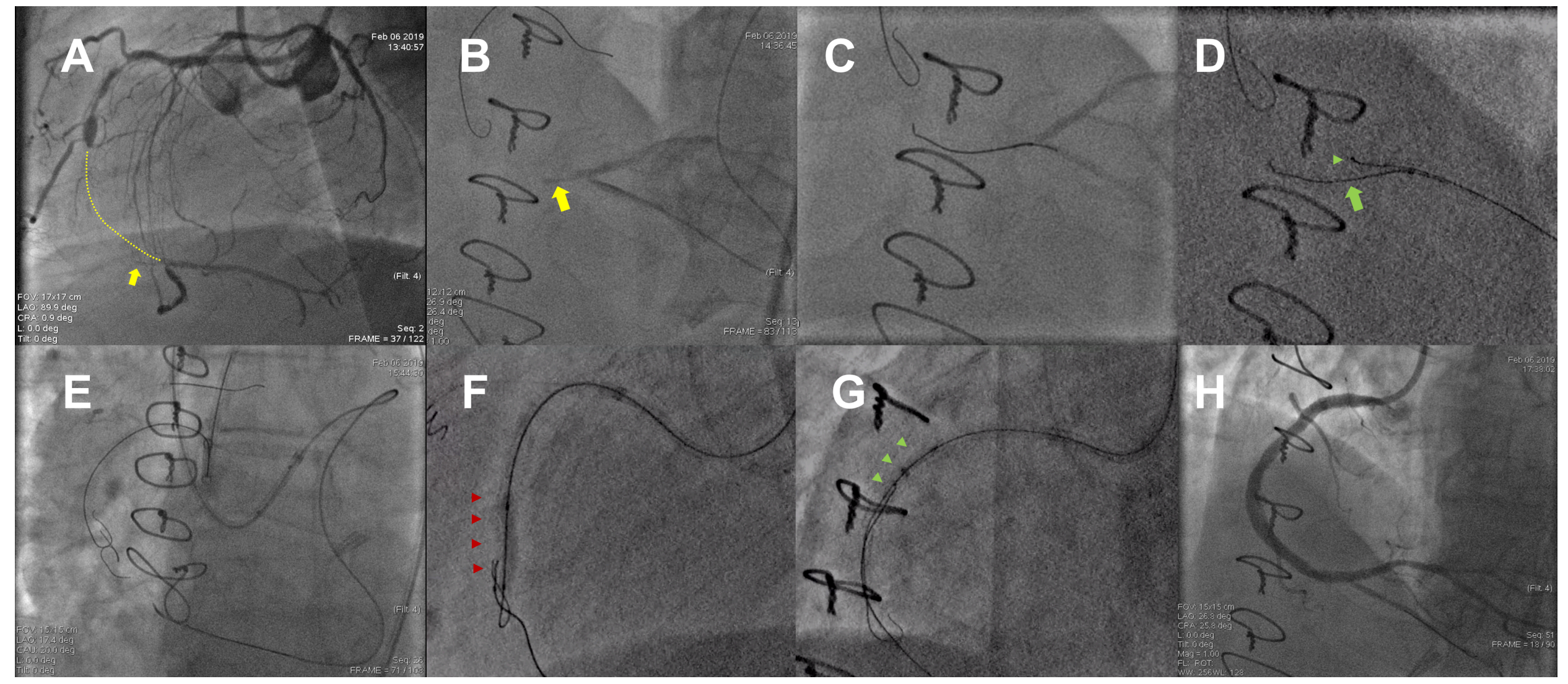

Figure 10 Clinical case, illustrating the challenges of percutaneous coronary intervention (PCI) in a bypassed right coronary artery (RCA) chronic total occlusion (CTO). Successful CTO PCI was achieved with retrograde application of dual lumen microcatheter in a patient with Canadian Cardiovascular Society grade 2-3 angina and two prior failed CTO attempts and a prior coronary artery bypass graft surgery .

Panel A: Dual angiography showing RCA CTO with proximal blunt stump, distal cap at bifurcation and retrograde filling of SVG at the crux (yellow arrow). Panel B: Retrograde microcatheter tip injection reveals distal anatomy showing the SVG graft (yellow arrow) as well.Panel C: Successful wiring to distal cap, but failed distal cap puncture (wire advances only to SVG graft) Panel D: Retrograde dual lumen microcatheter (Sasuke [Asahi Intecc, Nagoya, Japan]) was used for distal cap puncturing via the over-the-wire (OTW) port (green arrowhead). Panel E: Antegrade and retrograde wire knuckling. Panel F: Multiple failed reverse CART (controlled antegrade and retrograde subintimal tracking) with increasing balloon sizes (red arrowheads). Panel G: Successful GuideLiner (Vacular Solution, Minneapolis, MN, USA) assisted reverse CART (green arrowheads). Panel H: Final result after 3 DES implantation.

Reproduced from reference (83) 


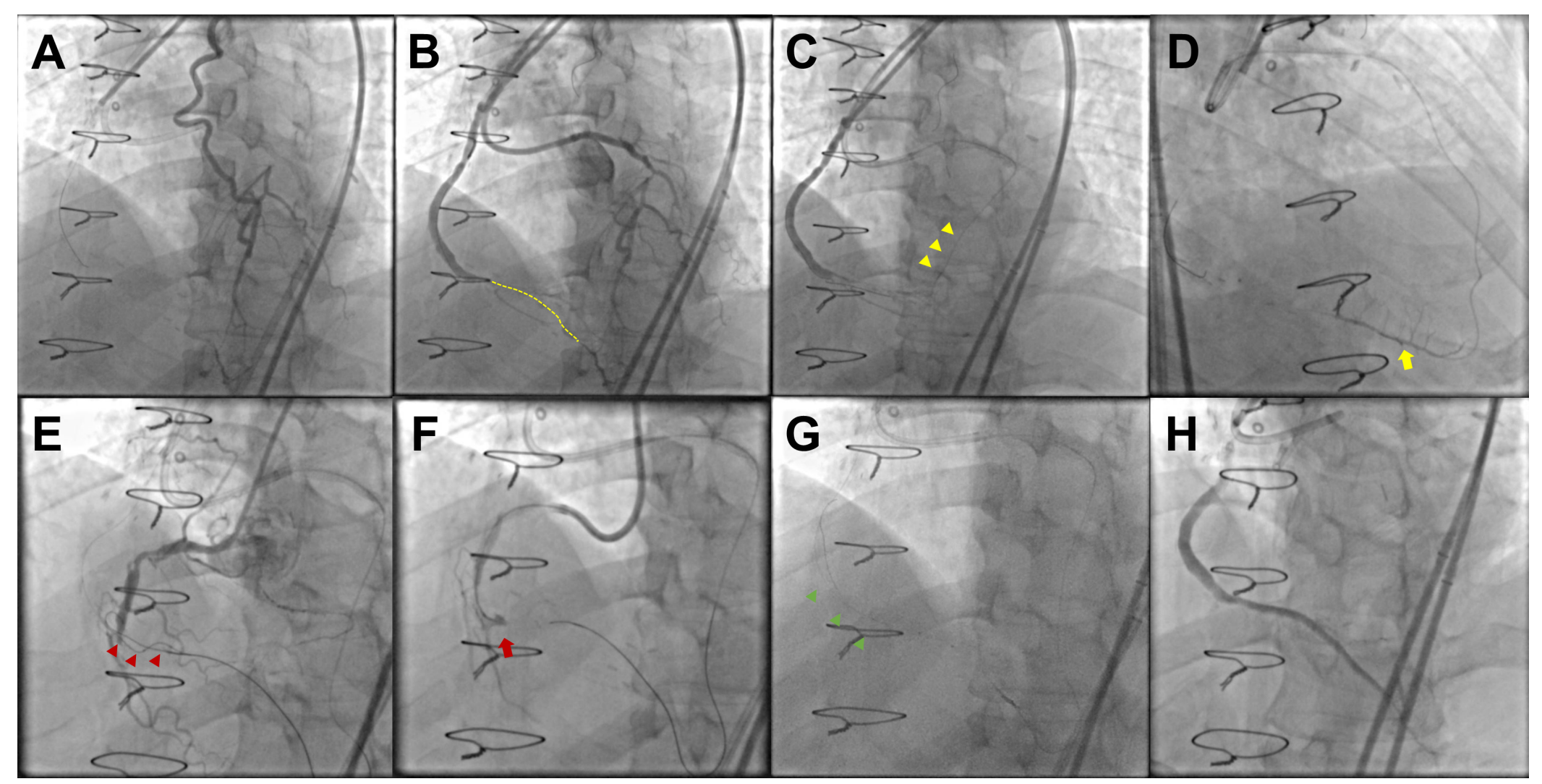

Figure 11 Clinical case, illustrating the importance of changing crossing strategy to successfully recanalize a challenging chronic total occlusion. Percutaneous coronary intervention (PCI) of a distal right coronary artery (RCA) chronic total occlusion (CTO) in a patient with Canadian Cardiovascular Society grade 3 angina and four prior failed CTO attempts and two prior coronary artery bypass graft surgeries.

Panel A-B: Triple coronary injection showing distal RCA CTO immediately distal to the SVG anastomotic site. Panel C: Multiple attempts for septal collateral crossing (surfing and contrast guided techniques) succeeded in advancing a guidewire to the distal RCA, but failed microcatheter advancement. Panel D: Successful contrast guided epicardial collateral crossing (Suoh 03, Caravel microcatheter [both Asahi Intecc., Nagoya, Japan]). Panel E: Several attempts to advance the retrograde guidewire distal to the SVG anastomosis failed.

Panel F: Multiple attempts to recanalize the native RCA failed, as the antegrade guidewire could not be advanced distal to the SVG anastomosis.Panel G: The reverse controlled antegrade and retrograde subintimal tracking (reverse CART) was successfully used to cross the CTO and advance the retrograde guidewire into the SVG-RCA, followed by guidewire externalization. Panel H: Final angiographic result after stent implantation. The patient had significant symptom improvement. 
The overall complication rate was $3.04 \%$, and occurred less frequently in technically successful procedures $(2.37 \%$ vs. $7.54 \%, \mathrm{p}<0.0001)$. The risk for complications was higher in more complex lesions (easy [J-CTO score 0] $1.36 \%$ vs. very difficult [J-CTO score $3 \leq$ ] $3.11 \%, p=0.01$ ) and with use of advanced crossing techniques (which were more commonly used in more complex lesions). This highlights the importance of weighing the risks and benefits of the procedure, both during discussions with patients and family (to determine whether CTO PCI should be done), but also during the procedure itself: implementing more complex CTO crossing strategies (such as retrograde crossing via epicardial collaterals) may predispose to increased risk for complications, which may be justified in some patients due to significant potential benefit, but not in some others. Accordingly, adjustment and improvement of advanced CTO crossing techniques - such as antegrade dissection re-entry and retrograde approach - may further improve procedural outcomes in more challenging patient populations and complex lesion subsets.

Despite the encouraging findings from our study and other contemporary registries, the success rates of CTO interventions in unselected patient cohorts remain low. Hannan et al. (New York State PCI Registry, $\mathrm{n}=4030$ patients) (36) reported 61.3\% success rate with $1.07 \%$ complication rates (vs. $1.06 \%$ for non-CTO PCI cases, $\mathrm{p}=0.95$ ). Ramunddal et al. showed similarly low procedural success rate (54.2\%) among 6,442 patients undergoing CTO intervention in the Swedish Coronary Angiography and Angioplasty Registry (SCAAR) (85). Habara et al. compared the acute outcomes of 3,229 CTO interventions among 56 high and low volume centers in Japan showing higher overall success rate in high-volume centers (90.6\% vs. 85.6\% p<0.001), without significant difference in in-hospital MACE rates $(0.45 \%$ vs. $0.62 \% \mathrm{p}=0.35)$, mostly attributed to higher antegrade success rate (33). Hence, CTO PCI should be performed by experienced operators at dedicated centers in order to achieve optimal results. The CTO PCI success rates in all comer registries (54\%-80\%) are significantly lower than those achieved at experienced centers (85\%90\%) (Table 7). 
Table 7 Procedural outcomes of multicenter CTO and general PCI registries in recent years.

\begin{tabular}{lccccc}
\multicolumn{1}{c}{ Authors } & $\begin{array}{c}\text { Center } \\
(\mathbf{n})\end{array}$ & $\begin{array}{c}\text { Case number } \\
(\mathbf{n})\end{array}$ & $\begin{array}{c}\text { Technical } \\
\text { success }\end{array}$ & $\begin{array}{c}\text { Procedural } \\
\text { success }\end{array}$ & $\begin{array}{c}\text { Overall } \\
\text { MACE }\end{array}$ \\
\hline DEDICATED CTO PCI REGISTRIES & & & & \\
\hline Christopoulos et al. (29)* & 11 & 1,036 & $91 \%$ & $90 \%$ & $1.7 \%$ \\
Suzuki et al. (35) $\dagger$ & 41 & 2,846 & $90 \%$ & $89 \%$ & $2.0 \%$ \\
Wilson et al. (30)* & 7 & 1,156 & $90 \%$ & - & $1.6 \%$ \\
Maeremans et al. (34) * & 17 & 1,253 & $89 \%$ & $86 \%$ & $2.6 \%$ \\
Sapontis et al. (17)* & 12 & 1,000 & $86 \%$ & $85 \%$ & $7.0 \%$ \\
Tajti et al. (86) * & $\mathbf{2 0}$ & $\mathbf{3 , 1 2 2}$ & $\mathbf{8 7 \%}$ & $\mathbf{8 5 \%}$ & $\mathbf{3 . 0 \%}$ \\
\hline ALL COMER CTO PCI REGISTRIES & & & & $1.6 \%$ \\
\hline Brilakis et al. (37) & - & 22,365 & - & $59 \%$ & $1.1 \%$ \\
Hannan et al. (36) & 61 & 4,030 & - & $61 \%$ & - \\
Ramunddal et al. (5) & - & 6,442 & - & $54 \%$ & $4.3 \%$ \\
\hline Tsai et al. (87) & 79 & 2,394 & $80 \%$ & $80 \%$ & \\
\hline
\end{tabular}

* Dedicated CTO PCI registries using the hybrid algorithm.

$\dagger 41$ highly skilled Japanese operators (Japanese CTO-PCI Expert Registry).

MACE, major adverse cardiovascular event; MI, myocardial infraction.

Sharma et al. presented that procedural outcomes of CTO interventions among operators who had received proctorship in using the hybrid approach was higher $(77.5 \% \mathrm{vs} .62 .1 \%$ $\mathrm{p}<0.0001$ ), especially in more complex cases (if J-CTO score $\geq 2$, the corresponding rates were $70.7 \%$ vs. $49.5 \%$, respectively, $\mathrm{p}=0.0003$ ) than those who did not receive mentorship (88).

Given the complexity of CTO PCI, becoming a successful CTO operator requires appropriate training and continued practice (Figure 12). Optimal training for CTO PCI remains controversial, as there are only few dedicated fellowship programs. Most operators learn CTO PCI after being in practice for a few years through participation in courses and proctoring. Developing experience in CTO PCI is important, both for achieving high success rates but also for minimizing the risk for complications and efficiently managing them if they occur $(36,37)$. 


\section{The learning curve of CTO PCI}

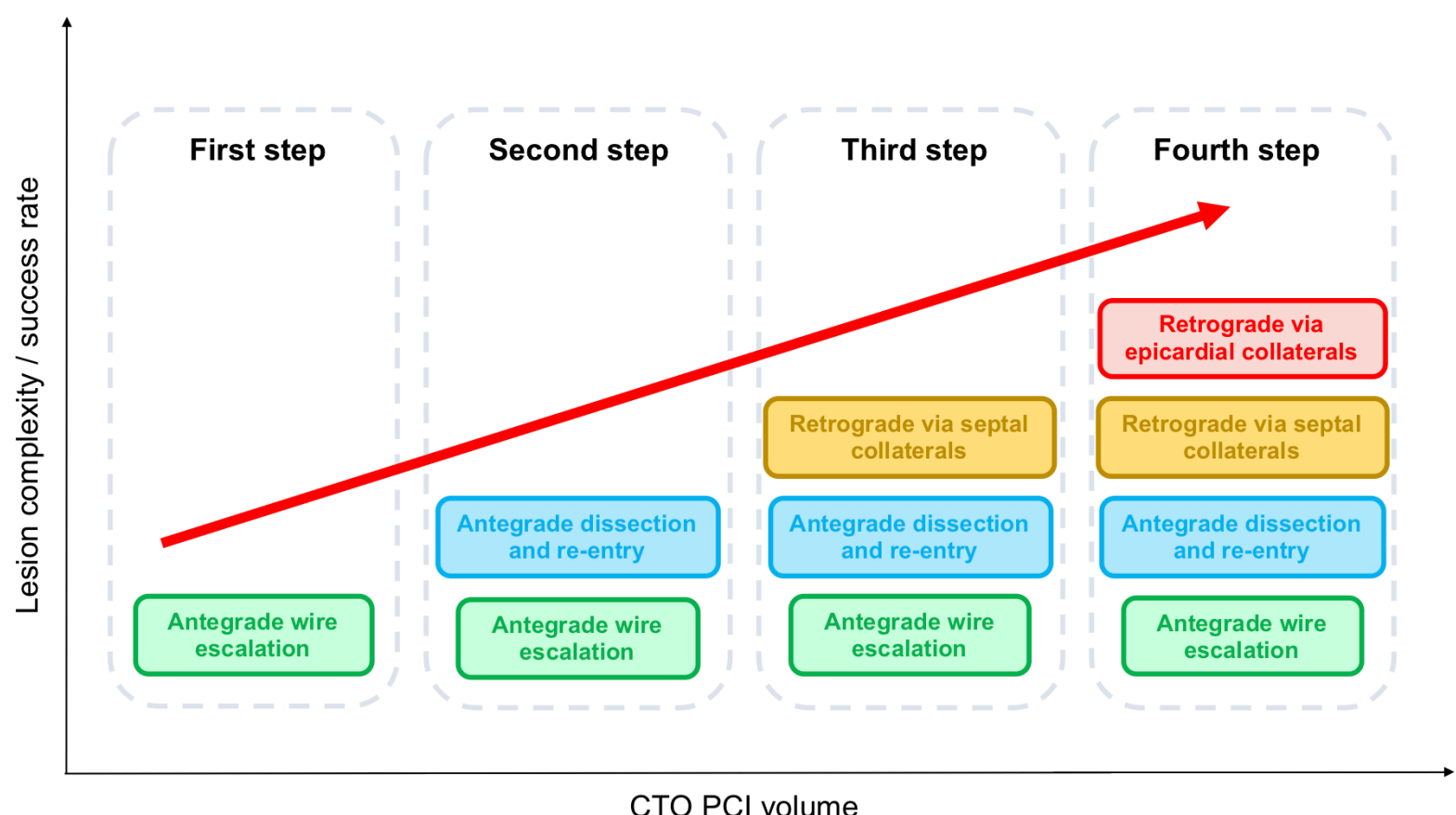

Figure 12 The four stages of learning CTO PCI.

Experience in performing CTO itnterventions is associated with application of advanced techniques in more complex patient and lesion subsets.

CTO, chronic total occlusion; PCI, percutaneous coronary intervention.

Reproduced from reference (65).

Bridging the gap will likely require development of novel equipment and techniques as well as development of comprehensive, high-volume (77) CTO PCI programs (89) and continued education through live case demonstrations (90), online educational contents (such as case libraries - https://www.ctomanual.org, https://www.pcimanual.org; or online sharing of novel research achievements - https://www.progresscto.org), CTO PCI workshops and proctorships (88). CTO PCI is one of the key components of the growing complex, high-risk, PCI programs $(91,92)$.

Our study has limitations. First, we did not have mid- and long-term follow up of the study patients. Second, there was no core laboratory assessment of the study angiograms or independent clinical event adjudication. Third, the procedures were performed in dedicated, high volume CTO centers by experienced operators, limiting the extrapolation to less experienced operators in low volume centers. Fourth, some centers only enrolled patients during part of the study period due to participation in other studies. Fifth, procedure related myocardial infarction events are site reported 
without systematic post-procedural biomarker assessment, hence the rate of such complications may be underestimated.

\section{CONCLUSIONS}

(i) Application of the hybrid approach resulted in high technical success rates (87\%) and acceptable rate of major in-hospital complications (3\%) across a large number of sites and operators in the US, Europe, and Russia.

(ii) Changing crossing strategy was required in $41 \%$ of cases with the final success strategy being antegrade wire escalation in $52 \%$, retrograde in $27 \%$, and antegrade dissection reentry in $21 \%$.

(iii) Bridging the gap between what is currently achieved (50-60\%) and what can be achieved (85-90\%) in chronic total occlusion intervention should be a major focus of upcoming research and education efforts.

(iv) CTO PCI can currently be achieved with high success and acceptable complication rates among various operators and patient populations in the US and Europe, highlighting the need for developing more CTO PCI centers of excellence in order to achieve the best possible clinical outcomes in this challenging patient and lesion group. 


\section{ACKNOWLEDGEMENTS}

I would like to express my deepest gratitude to those who have supported me during my scientific work.

Imre Ungi, Associate Professor and Head of the Division of Invasive Cardiology Second Department of Internal Medicine and Cardiology Center. Thank you for your continuous support as a mentor, both in my clinical and research work. You gave me a secure background since medical school, and throughout my fellowships in Hungary and the United States.

Ferenc T. Nagy, Senior Lecturer, Division of Invasive Cardiology Second Department of Internal Medicine and Cardiology Center. Thank you for your valuable advices and management both in my clinical practice and research work.

Emmanouil S. Brilakis, Associate Professor of Medicine, University of Texas Southwestern Medical School and Director of the Center for Complex Coronary Interventions at the Minneapolis Heart Institute. I cannot thank him enough for his support, friendship, and tremendous opportunity to work in a highly stimulating research environment. Thank you for your indispensable scientific guidance throughout my post-graduate fellowship in the US and for showing me how to be efficient in academic life.

I would also like to express my acknowledgement to Prof. Dr. Tamás Forster, Head of the Second Department of Internal Medicine and Cardiology Center, for all his support.

I wish to express my special gratitude to my family. My mother, Mónika, my father, László, my sisters, Franciska and Krisztina, my grandparents, Piroska, János and Márton, my nephew András and my brother in law, Zsolt. You made all this possible with your enormous love and encouragement throughout my years both in Hungary and the United States. Thank you for your continuous support and for showing me how to live a valuable life.

Last but not least, I would like thank my colleagues at the Division of Interventional Cardiology of Szeged, and the Minneapolis Heart Institute Foundation and its employees for supporting my scientific work throughout career in Hungary and the United States. 


\section{REFERENCES}

1. Brilakis ES. Manual of Coronary Chronic Total Occlusion Interventions: A Stepby-Step Approach. $2^{\text {nd }}$ edition, Academic Press, 2017.

2. Fefer P, Knudtson ML, Cheema AN et al. Current perspectives on coronary chronic total occlusions: the Canadian Multicenter Chronic Total Occlusions Registry. J Am Coll Cardiol 2012;59:991-7.

3. Jeroudi OM, Alomar ME, Michael TT et al. Prevalence and management of coronary chronic total occlusions in a tertiary Veterans Affairs hospital. Catheter Cardiovasc Interv 2014;84:637-43.

4. Christofferson RD, Lehmann KG, Martin GV, Every N, Caldwell JH, Kapadia SR. Effect of chronic total coronary occlusion on treatment strategy. Am J Cardiol 2005;95:1088-91.

5. Ramunddal T, Hoebers LP, Henriques JP et al. Chronic total occlusions in Sweden-a report from the Swedish Coronary Angiography and Angioplasty Registry (SCAAR). PLoS One 2014;9:e103850.

6. Azzalini L, Jolicoeur EM, Pighi M et al. Epidemiology, Management Strategies, and Outcomes of Patients With Chronic Total Coronary Occlusion. Am J Cardiol 2016;118:11281135 .

7. Patel MR, Dehmer GJ, Hirshfeld JW, Smith PK, Spertus JA. ACCF/SCAI/STS/AATS/AHA/ASNC 2009 Appropriateness Criteria for Coronary Revascularization: A Report of the American College of Cardiology Foundation Appropriateness Criteria Task Force, Society for Cardiovascular Angiography and Interventions, Society of Thoracic Surgeons, American Association for Thoracic Surgery, American Heart Association, and the American Society of Nuclear Cardiology: Endorsed by the American Society of Echocardiography, the Heart Failure Society of America, and the Society of Cardiovascular Computed Tomography. Circulation 2009;119:1330-52.

8. Patel MR, Calhoon JH, Dehmer GJ et al. ACC/AATS/AHA/ASE/ASNC/SCAI/SCCT/STS 2016 Appropriate Use Criteria for Coronary Revascularization in Patients With Acute Coronary Syndromes: A Report of the American College of Cardiology Appropriate Use Criteria Task Force, American Association for Thoracic Surgery, American Heart Association, American Society of Echocardiography, American Society of 
Nuclear Cardiology, Society for Cardiovascular Angiography and Interventions, Society of Cardiovascular Computed Tomography, and the Society of Thoracic Surgeons. J Am Coll Cardiol 2017;69:570-591.

9. Patel MR, Calhoon JH, Dehmer GJ et al. ACC/AATS/AHA/ASE/ASNC/SCAI/SCCT/STS 2017 Appropriate Use Criteria for Coronary Revascularization in Patients With Stable Ischemic Heart Disease: A Report of the American College of Cardiology Appropriate Use Criteria Task Force, American Association for Thoracic Surgery, American Heart Association, American Society of Echocardiography, American Society of Nuclear Cardiology, Society for Cardiovascular Angiography and Interventions, Society of Cardiovascular Computed Tomography, and Society of Thoracic Surgeons. J Am Coll Cardiol 2017;69:2212-2241.

10. Neumann FJ, Sousa-Uva M, Ahlsson A et al. 2018 ESC/EACTS Guidelines on myocardial revascularization. Eur Heart J 2019;40:87-165.

11. Henriques JP, Hoebers LP, Ramunddal T et al. Percutaneous Intervention for Concurrent Chronic Total Occlusions in Patients With STEMI: The EXPLORE Trial. J Am Coll Cardiol 2016;68:1622-1632.

12. Lee SW, Lee PH, Ahn JM et al. Randomized Trial Evaluating Percutaneous Coronary Intervention for the Treatment of Chronic Total Occlusion. Circulation 2019;139:16741683.

13. Werner GS, Martin-Yuste V, Hildick-Smith D et al. A randomized multicentre trial to compare revascularization with optimal medical therapy for the treatment of chronic total coronary occlusions. Eur Heart J 2018.

14. Mashayekhi K, Nuhrenberg TG, Toma A et al. A Randomized Trial to Assess Regional Left Ventricular Function After Stent Implantation in Chronic Total Occlusion: The REVASC Trial. JACC Cardiovasc Interv 2018;11:1982-1991.

15. Obedinskiy AA, Kretov EI, Boukhris M et al. The IMPACTOR-CTO Trial. JACC Cardiovasc Interv 2018;11:1309-1311.

16. Han H, Chao H, Guerra A et al. Evolution of the American College of Cardiology/American Heart Association Clinical Guidelines. J Am Coll Cardiol 2015;65:2726-34.

17. Sapontis J, Salisbury AC, Yeh RW et al. Early Procedural and Health Status Outcomes After Chronic Total Occlusion Angioplasty: A Report From the OPEN-CTO Registry 
(Outcomes, Patient Health Status, and Efficiency in Chronic Total Occlusion Hybrid Procedures). JACC Cardiovasc Interv 2017;10:1523-1534.

18. Christakopoulos GE, Christopoulos G, Carlino M et al. Meta-analysis of clinical outcomes of patients who underwent percutaneous coronary interventions for chronic total occlusions. Am J Cardiol 2015;115:1367-75.

19. Tomasello SD, Boukhris M, Giubilato S et al. Management strategies in patients affected by chronic total occlusions: results from the Italian Registry of Chronic Total Occlusions. Eur Heart J 2015.

20. Yang JH, Kim BS, Jang WJ et al. Optimal Medical Therapy vs. Percutaneous Coronary Intervention for Patients With Coronary Chronic Total Occlusion - A PropensityMatched Analysis. Circ J 2016;80:211-7.

21. Jang WJ, Yang JH, Choi SH et al. Long-term survival benefit of revascularization compared with medical therapy in patients with coronary chronic total occlusion and welldeveloped collateral circulation. JACC Cardiovasc Interv 2015;8:271-9.

22. Bruckel JT, Jaffer FA, O'Brien C, Stone L, Pomerantsev E, Yeh RW. Angina Severity, Depression, and Response to Percutaneous Revascularization in Patients With Chronic Total Occlusion of Coronary Arteries. J Invasive Cardiol 2016;28:44-51.

23. Rossello X, Pujadas S, Serra A et al. Assessment of Inducible Myocardial Ischemia, Quality of Life, and Functional Status After Successful Percutaneous Revascularization in Patients With Chronic Total Coronary Occlusion. Am J Cardiol 2016;117:720-6.

24. Mashayekhi K, Neuser H, Kraus A et al. Successful Percutaneous Coronary Intervention Improves Cardiopulmonary Exercise Capacity in Patients With Chronic Total Occlusions. J Am Coll Cardiol 2017;69:1095-1096.

25. Abdullah SM, Hastings JL, Amsavelu S et al. Percutaneous Coronary Intervention of Coronary Chronic Total Occlusions Improves Peak Oxygen Uptake During Cardiopulmonary Exercise Testing. J Invasive Cardiol 2017;29:83-91.

26. Di Marco A, Paglino G, Oloriz T et al. Impact of a chronic total occlusion in an infarct-related artery on the long-term outcome of ventricular tachycardia ablation. J Cardiovasc Electrophysiol 2015;26:532-9.

27. Iannaccone M, D'Ascenzo F, Piazza F et al. Optimal medical therapy vs. coronary revascularization for patients presenting with chronic total occlusion: A meta-analysis of 
randomized controlled trials and propensity score adjusted studies. Catheter Cardiovasc Interv 2019;93:E320-E325.

28. Brilakis ES, Grantham JA, Rinfret S et al. A percutaneous treatment algorithm for crossing coronary chronic total occlusions. JACC Cardiovasc Interv 2012;5:367-79.

29. Christopoulos G, Karmpaliotis D, Alaswad K et al. Application and outcomes of a hybrid approach to chronic total occlusion percutaneous coronary intervention in a contemporary multicenter US registry. Int J Cardiol 2015;198:222-228.

30. Wilson WM, Walsh SJ, Yan AT et al. Hybrid approach improves success of chronic total occlusion angioplasty. Heart 2016;102:1486-93.

31. Galassi AR, Sianos G, Werner GS et al. Retrograde Recanalization of Chronic Total Occlusions in Europe: Procedural, In-Hospital, and Long-Term Outcomes From the Multicenter ERCTO Registry. J Am Coll Cardiol 2015;65:2388-400.

32. Okamura A, Yamane M, Muto $\mathrm{M}$ et al. Complications during retrograde approach for chronic coronary total occlusion: Sub-analysis of Japanese multicenter registry. Catheter Cardiovasc Interv 2016;88:7-14.

33. Habara M, Tsuchikane E, Muramatsu T et al. Comparison of percutaneous coronary intervention for chronic total occlusion outcome according to operator experience from the Japanese retrograde summit registry. Catheter Cardiovasc Interv 2016;87:1027-35.

34. Maeremans J, Walsh S, Knaapen P et al. The Hybrid Algorithm for Treating Chronic Total Occlusions in Europe: The RECHARGE Registry. J Am Coll Cardiol 2016;68:1958-1970.

35. Suzuki Y, Tsuchikane E, Katoh O et al. Outcomes of Percutaneous Coronary Interventions for Chronic Total Occlusion Performed by Highly Experienced Japanese Specialists: The First Report From the Japanese CTO-PCI Expert Registry. JACC Cardiovasc Interv 2017;10:2144-2154.

36. Hannan EL, Zhong Y, Jacobs AK et al. Patients With Chronic Total Occlusions Undergoing Percutaneous Coronary Interventions: Characteristics, Success, and Outcomes. Circ Cardiovasc Interv 2016;9:e003586.

37. Brilakis ES, Banerjee S, Karmpaliotis D et al. Procedural Outcomes of Chronic Total Occlusion Percutaneous Coronary Intervention: A Report From the NCDR (National Cardiovascular Data Registry). JACC Cardiovascular interventions 2015;8:245-53. 
38. Morino $\mathrm{Y}$, Abe $\mathrm{M}$, Morimoto $\mathrm{T}$ et al. Predicting successful guidewire crossing through chronic total occlusion of native coronary lesions within 30 minutes: the J-CTO (Multicenter CTO Registry in Japan) score as a difficulty grading and time assessment tool. JACC Cardiovascular interventions 2011;4:213-21.

39. Christopoulos G, Wyman RM, Alaswad K et al. Clinical Utility of the JapanChronic Total Occlusion Score in Coronary Chronic Total Occlusion Interventions: Results from a Multicenter Registry. Circ Cardiovasc Interv 2015;8:e002171.

40. Tanaka H, Morino Y, Abe M et al. Impact of J-CTO score on procedural outcome and target lesion revascularisation after percutaneous coronary intervention for chronic total occlusion: a substudy of the J-CTO Registry (Multicentre CTO Registry in Japan). EuroIntervention 2016;11:981-8.

41. Abe M, Morimoto T, Morino Y et al. Association between J-CTO score and longterm target lesion revascularization rate after successful chronic total coronary occlusion angioplasty (from the J-CTO Registry). Catheter Cardiovasc Interv 2019;93:1025-1032.

42. Christopoulos G, Kandzari DE, Yeh RW et al. Development and Validation of a Novel Scoring System for Predicting Technical Success of Chronic Total Occlusion Percutaneous Coronary Interventions: The PROGRESS CTO (Prospective Global Registry for the Study of Chronic Total Occlusion Intervention) Score. JACC Cardiovasc Interv 2016;9:1-9.

43. Maeremans J, Spratt JC, Knaapen P et al. Towards a contemporary, comprehensive scoring system for determining technical outcomes of hybrid percutaneous chronic total occlusion treatment: The RECHARGE score. Catheter Cardiovasc Interv 2017.

44. Alessandrino G, Chevalier B, Lefevre T et al. A Clinical and Angiographic Scoring System to Predict the Probability of Successful First-Attempt Percutaneous Coronary Intervention in Patients With Total Chronic Coronary Occlusion. JACC Cardiovasc Interv 2015;8:1540-8.

45. Szijgyarto Z, Rampat R, Werner GS et al. Derivation and Validation of a Chronic Total Coronary Occlusion Intervention Procedural Success Score From the 20,000-Patient EuroCTO Registry: The EuroCTO (CASTLE) Score. JACC Cardiovasc Interv 2019;12:335-342.

46. Galassi AR, Boukhris M, Azzarelli S, Castaing M, Marza F, Tomasello SD. Percutaneous Coronary Revascularization for Chronic Total Occlusions: A Novel Predictive Score of Technical Failure Using Advanced Technologies. JACC Cardiovasc Interv 2016. 
47. Ellis SG, Burke MN, Murad MB et al. Predictors of Successful Hybrid-Approach Chronic Total Coronary Artery Occlusion Stenting: An Improved Model With Novel Correlates. JACC Cardiovase Interv 2017;10:1089-1098.

48. Karatasakis A, Danek BA, Karmpaliotis D et al. Comparison of various scores for predicting success of chronic total occlusion percutaneous coronary intervention. Int J Cardiol 2016;224:50-56.

49. Tajti P, Burke MN, Karmpaliotis D et al. Update in the Percutaneous Management of Coronary Chronic Total Occlusions. JACC Cardiovasc Interv 2018;11:615-625.

50. Tajti P, Xenogiannis I, Najar H, Brilakis ES. Management of Balloon Undilatable CTOs. Cardiac Interventions Today 2018;(May/June 2018).

51. Rinfret S, Joyal D, Spratt JC, Buller CE. Chronic total occlusion percutaneous coronary intervention case selection and techniques for the antegrade-only operator. Catheter Cardiovasc Interv 2014.

52. Michael TT, Papayannis AC, Banerjee S, Brilakis ES. Subintimal dissection/reentry strategies in coronary chronic total occlusion interventions. Circ Cardiovasc Interv 2012;5:729-38.

53. Colombo A, Mikhail GW, Michev I et al. Treating chronic total occlusions using subintimal tracking and reentry: the STAR technique. Catheter Cardiovasc Interv 2005;64:407-11; discussion 412.

54. Whitlow PL, Burke MN, Lombardi WL et al. Use of a novel crossing and re-entry system in coronary chronic total occlusions that have failed standard crossing techniques: results of the FAST-CTOs (Facilitated Antegrade Steering Technique in Chronic Total Occlusions) trial. JACC Cardiovasc Interv 2012;5:393-401.

55. Werner GS. The BridgePoint devices to facilitate recanalization of chronic total coronary occlusions through controlled subintimal reentry. Expert Rev Med Devices 2011;8:23-9.

56. Rathore $\mathrm{S}$, Katoh $\mathrm{O}$, Matsuo $\mathrm{H}$ et al. Retrograde percutaneous recanalization of chronic total occlusion of the coronary arteries: procedural outcomes and predictors of success in contemporary practice. Circ Cardiovasc Interv 2009;2:124-32.

57. Saito S. Different strategies of retrograde approach in coronary angioplasty for chronic total occlusion. Catheter Cardiovasc Interv 2008;71:8-19. 
58. Brilakis ES, Grantham JA, Thompson CA et al. The retrograde approach to coronary artery chronic total occlusions: a practical approach. Catheter Cardiovasc Interv 2012;79:3-19.

59. Joyal D, Thompson CA, Grantham JA, Buller CE, Rinfret S. The retrograde technique for recanalization of chronic total occlusions: a step-by-step approach. JACC Cardiovasc Interv 2012;5:1-11.

60. Michael TT, Mogabgab O, Fuh E et al. Application of the "hybrid approach" to chronic total occlusion interventions: a detailed procedural analysis. J Interv Cardiol 2014;27:3643.

61. Christopoulos G, Menon RV, Karmpaliotis D et al. Application of the "hybrid approach" to chronic total occlusions in patients with previous coronary artery bypass graft surgery (from a Contemporary Multicenter US registry). Am J Cardiol 2014;113:1990-4.

62. Pershad A, Eddin M, Girotra S, Cotugno R, Daniels D, Lombardi W. Validation and incremental value of the hybrid algorithm for CTO PCI. Catheter Cardiovasc Interv 2014;84:654-9.

63. Sabbagh AE, Banerjee S, Brilakis ES. Illustration of the 'hybrid' approach to chronic total occlusion crossing. Interventional Cardiology 2012;4:639-643.

64. Christopoulos G, Menon RV, Karmpaliotis D et al. The Efficacy and Safety of the "Hybrid" Approach to Coronary Chronic Total Occlusions: Insights From a Contemporary Multicenter US Registry and Comparison With Prior Studies. J Invasive Cardiol 2014;26:427-32.

65. Tajti P, Ungi I. Az anterográd technikák szerepe a krónikus teljes koszorúérelzáródás perkután revaszkularizációjában. Cardiologia Hungarica 2018;48:330-339.

66. Karacsonyi J, Tajti P, Rangan BV et al. Randomized Comparison of a CrossBoss First Versus Standard Wire Escalation Strategy for Crossing Coronary Chronic Total Occlusions: The CrossBoss First Trial. JACC Cardiovasc Interv 2018;11:225-233.

67. Azzalini L, Dautov R, Brilakis ES et al. Procedural and longer-term outcomes of wire- versus device-based antegrade dissection and re-entry techniques for the percutaneous revascularization of coronary chronic total occlusions. Int J Cardiol 2017;231:78-83.

68. Thygesen K, Alpert JS, Jaffe AS et al. Third universal definition of myocardial infarction. J Am Coll Cardiol 2012;60:1581-98. 
69. Morino Y, Abe M, Morimoto T et al. Predicting successful guidewire crossing through chronic total occlusion of native coronary lesions within 30 minutes: the J-CTO (Multicenter CTO Registry in Japan) score as a difficulty grading and time assessment tool. JACC Cardiovasc Interv 2011;4:213-21.

70. Danek BA, Karatasakis A, Karmpaliotis D et al. Development and Validation of a Scoring System for Predicting Periprocedural Complications During Percutaneous Coronary Interventions of Chronic Total Occlusions: The Prospective Global Registry for the Study of Chronic Total Occlusion Intervention (PROGRESS CTO) Complications Score. J Am Heart Assoc $2016 ; 5$.

71. Vo MN, McCabe JM, Lombardi WL, Ducas J, Ravandi A, Brilakis ES. Adoption of the hybrid CTO approach by a single non-CTO operator: procedural and clinical outcomes. J Invasive Cardiol 2015;27:139-44.

72. Daniels DV, Banerjee S, Alaswad K et al. Safety and efficacy of the hybrid approach in coronary chronic total occlusion percutaneous coronary intervention: The Hybrid Video Registry. Catheter Cardiovasc Interv 2017.

73. Patel SM, Pokala NR, Menon RV et al. Prevalence and treatment of "balloonuncrossable" coronary chronic total occlusions. J Invasive Cardiol 2015;27:78-84.

74. Karacsonyi J, Karmpaliotis D, Alaswad K et al. Prevalence, indications and management of balloon uncrossable chronic total occlusions: Insights from a contemporary multicenter US registry. Catheter Cardiovasc Interv 2017;90:12-20.

75. Ojeda S, Pan M, Gutierrez A et al. Bifurcation lesions involved in the recanalization process of coronary chronic total occlusions: Incidence, treatment and clinical implications. Int $\mathbf{J}$ Cardiol 2017;230:432-438.

76. Tajti P, Karmpaliotis D, Alaswad K et al. Prevalence, Presentation and Treatment of 'Balloon Undilatable' Chronic Total Occlusions: Insights from a Multicenter US Registry. Catheter Cardiovasc Interv 2018.

77. Michael TT, Karmpaliotis D, Brilakis ES et al. Temporal trends of fluoroscopy time and contrast utilization in coronary chronic total occlusion revascularization: insights from a multicenter united states registry. Catheter Cardiovasc Interv 2015;85:393-9. 
78. Tajti P, Alaswad K, Karmpaliotis D et al. In-hospital Outcomes of Attempting More Than One Chronic Total Coronary Occlusion Through Percutaneous Intervention During the Same Procedure. Am J Cardiol 2018; [Article in Press].

79. Karatasakis A, Danek BA, Karmpaliotis D et al. Impact of Proximal Cap Ambiguity on Outcomes of Chronic Total Occlusion Percutaneous Coronary Intervention: Insights From a Multicenter US Registry. J Invasive Cardiol 2016;28:391-396.

80. Karacsonyi J, Karmpaliotis D, Alaswad K et al. Impact of Calcium on Chronic Total Occlusion Percutaneous Coronary Interventions. Am J Cardiol 2017;120:40-46.

81. Teramoto $\mathrm{T}$, Tsuchikane $\mathrm{E}$, Matsuo $\mathrm{H}$ et al. Initial success rate of percutaneous coronary intervention for chronic total occlusion in a native coronary artery is decreased in patients who underwent previous coronary artery bypass graft surgery. JACC Cardiovascular interventions 2014;7:39-46.

82. Brilakis ES, O'Donnell CI, Penny W et al. Percutaneous Coronary Intervention in Native Coronary Arteries Versus Bypass Grafts in Patients With Prior Coronary Artery Bypass Graft Surgery: Insights From the Veterans Affairs Clinical Assessment, Reporting, and Tracking Program. JACC Cardiovasc Interv 2016;9:884-93.

83. Tajti P, Abu-Fanne R, Ungi I, Katona A, Sasi V, Nagy FT. Kettős lumenú mikrokatéterek alkalmazása krónikus teljes koronária okklúzió katéteres revaszkularizációjában egy komplex beavatkozás tanulságai. Cardiologia Hungarica 2019.

84. Tajti P, Karmpaliotis D, Alaswad K et al. In-Hospital Outcomes of Chronic Total Occlusion Percutaneous Coronary Interventions in Patients With Prior Coronary Artery Bypass Graft Surgery. Circ Cardiovasc Interv 2019;12:e007338.

85. Ramunddal T, Hoebers LP, Henriques JP et al. Prognostic Impact of Chronic Total Occlusions: A Report From SCAAR (Swedish Coronary Angiography and Angioplasty Registry). JACC Cardiovascular interventions 2016;9:1535-44.

86. Tajti P, Karmpaliotis D, Alaswad K et al. The Hybrid Approach to Chronic Total Occlusion Percutaneous Coronary Intervention: Update From the PROGRESS CTO Registry. JACC Cardiovasc Interv 2018.

87. Tsai TT, Stanislawski MA, Shunk KA et al. Contemporary Incidence, Management, and Long-Term Outcomes of Percutaneous Coronary Interventions for Chronic 
Coronary Artery Total Occlusions: Insights From the VA CART Program. JACC Cardiovasc Interv 2017;10:866-875.

88. Sharma V, Jadhav ST, Harcombe AA et al. Impact of proctoring on success rates for percutaneous revascularisation of coronary chronic total occlusions. Open Heart 2015;2:e000228.

89. Brilakis ES, Vo MN. How to develop a successful chronic total occlusion percutaneous coronary intervention program. Cardiovasc Revasc Med 2016;17:3-4.

90. Shimura T, Yamamoto M, Tsuchikane E et al. Safety of Live Case Demonstrations in Patients Undergoing Percutaneous Coronary Intervention for Chronic Total Occlusion. Am J Cardiol 2016;118:967-73.

91. Kirtane AJ, Doshi D, Leon MB et al. Treatment of Higher-Risk Patients With an Indication for Revascularization: Evolution Within the Field of Contemporary Percutaneous Coronary Intervention. Circulation 2016;134:422-31.

92. Kalra A, Bhatt DL, Pinto DS et al. Accreditation and funding for a 24-month advanced interventional cardiology fellowship program: A call-to-action for optimal training of the next generation of interventionalists. Catheter Cardiovasc Interv 2016;88:1010-1015. 



\section{The Hybrid Approach to Chronic Total Occlusion Percutaneous Coronary Intervention}

\section{Update From the PROGRESS CTO Registry}

Peter Tajti, MD, ${ }^{\mathrm{a}, \mathrm{b}}$ Dimitri Karmpaliotis, MD, ${ }^{\mathrm{c}}$ Khaldoon Alaswad, MD, ${ }^{\mathrm{d}}$ Farouc A. Jaffer, MD, PHD, Robert W. Yeh, MD, ${ }^{\mathrm{f}}$ Mitul Patel, MD, ${ }^{\mathrm{g}}$ Ehtisham Mahmud, MD, ${ }^{\mathrm{g}}$ James W. Choi, MD, ${ }^{\mathrm{h}} \mathrm{M}$. Nicholas Burke, MD, ${ }^{\mathrm{a}}$ Anthony H. Doing, MD, ${ }_{1}$ Phil Dattilo, MD, ${ }^{1}$ Catalin Toma, MD, ${ }^{j}$ A.J. Conrad Smith, MD, ${ }^{j}$ Barry Uretsky, MD, ${ }^{k}$ Elizabeth Holper, MD, ${ }^{1}$ R. Michael Wyman, MD, ${ }^{\mathrm{m}}$ David E. Kandzari, MD, ${ }^{\mathrm{n}}$ Santiago Garcia, MD, ${ }^{\circ}$ Oleg Krestyaninov, MD, ${ }^{\mathrm{p}}$ Dmitrii Khelimskii, MD, ${ }^{\mathrm{p}}$ Michalis Koutouzis, MD, ${ }^{\mathrm{q}}$ Ioannis Tsiafoutis, MD, ${ }^{\mathrm{q}}$ Jeffrey W. Moses, MD, ${ }^{\mathrm{c}}$ Nicholas J. Lembo, MD, ${ }^{\mathrm{C}}$ Manish Parikh, MD, ${ }^{\mathrm{C}}$ Ajay J. Kirtane, MD, ${ }^{\mathrm{c}}$ Ziad A. Ali, MD, Darshan Doshi, MD, ${ }^{\mathrm{c}}$ Bavana V. Rangan, BDS, MPH, ${ }^{\mathrm{r}}$ Imre Ungi, MD, PHD, ${ }^{\mathrm{b}}$ Subhash Banerjee, MD, ${ }^{\mathrm{r}}$ Emmanouil S. Brilakis, MD, $\mathrm{PHD}^{\mathrm{a}, \mathrm{r}}$

\section{ABSTRACT}

OBJECTIVES The aim of this study was to determine the techniques and outcomes of hybrid chronic total occlusion (CTO) percutaneous coronary intervention (PCl) in a diverse group of patients and operators on 2 continents.

BACKGROUND CTO PCI has been evolving with constant improvement of equipment and techniques.

METHODS Contemporary outcomes of CTO PCI were examined by analyzing the clinical, angiographic, and procedural characteristics of 3,122 СТO interventions performed in 3,055 patients at 20 centers in the United States, Europe, and Russia.

RESULTS The mean age was $65 \pm 10$ years, and $85 \%$ of the patients were men, with high prevalence of diabetes (43\%), prior myocardial infarction (46\%), prior coronary artery bypass graft surgery (33\%), and prior $\mathrm{PCl}(65 \%)$. The СTO target vessels were the right coronary artery (55\%), left anterior descending coronary artery (24\%), and left circumflex coronary artery (20\%). The mean J-CTO (Multicenter Chronic Total Occlusion Registry of Japan) and PROGRESS CTO (Prospective Global Registry for the Study of Chronic Total Occlusion Intervention) scores were $2.4 \pm 1.3$ and $1.3 \pm 1.0$, respectively. The overall technical and procedural success rate was $87 \%$ and $85 \%$, respectively, and the rate of inhospital major complications was $3.0 \%$. The final successful crossing strategy was antegrade wire escalation in $52.0 \%$, retrograde in $27.1 \%$, and antegrade dissection re-entry in $20.9 \%$; $>1$ crossing strategy was required in $40.9 \%$. Median contrast volume, air kerma radiation dose, and procedure and fluoroscopy time were $270 \mathrm{ml}$ (interquartile range: 200 to $360 \mathrm{ml}$ ), $2.9 \mathrm{~Gy}$ (interquartile range: 1.7 to $4.7 \mathrm{~Gy}$ ), $123 \mathrm{~min}$ (interquartile range: 81 to $188 \mathrm{~min}$ ) and $47 \mathrm{~min}$ (interquartile range: 29 to $77 \mathrm{~min})$, respectively.

CONCLUSIONS CTO PCI is currently being performed with high success and acceptable complication rates among various experienced centers in the United States, Europe, and Russia. (Prospective Global Registry for the Study of Chronic Total Occlusion Intervention [PROGRESS CTO]; NCTO2061436) (J Am Coll Cardiol Intv 2018;11:1325-35)

(c) 2018 the American College of Cardiology Foundation. Published by Elsevier. All rights reserved.

From the ${ }^{a}$ Minneapolis Heart Institute, Abbott Northwestern Hospital, Minneapolis, Minnesota; ${ }^{b}$ University of Szeged, Division of Invasive Cardiology, Second Department of Internal Medicine and Cardiology Center, Szeged, Hungary; 'Columbia University, New York, New York; ${ }^{\mathrm{d}}$ Henry Ford Hospital, Detroit, Michigan; ${ }^{\mathrm{e}}$ Massachusetts General Hospital, Boston, Massachusetts; ${ }^{\mathrm{f}}$ Beth Israel Deaconess Medical Center, Boston, Massachusetts; ${ }^{g}$ VA San Diego Healthcare System and University of California, San Diego, La Jolla, California; ${ }^{\mathrm{h}}$ Baylor Heart and Vascular Hospital, Dallas, Texas; ${ }^{\mathrm{i}}$ Medical Center of the Rockies, Loveland, Col-

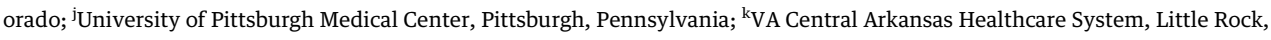
Arkansas; ${ }^{1}$ The Heart Hospital Baylor Plano, Plano, Texas; ${ }^{\mathrm{m}}$ Torrance Memorial Medical Center, Torrance, California; ${ }^{n}$ Piedmont Heart Institute, Atlanta, Georgia; ${ }^{\circ}$ VA Minneapolis Healthcare System and University of Minnesota, Minneapolis, 


A B B R E V I A T I O N S
A N D A C R O N Y M S
CABG = coronary artery
bypass graft
CCS = Canadian Cardiovascular
Society
CTO = chronic total occlusion
IQR = interquartile range
MACE = major adverse
cardiac event(s)
MI = myocardial infarction
PCI = percutaneous coronary
intervention
TIMI = Thrombolysis In
Myocardial Infarction

T he hybrid approach to chronic total occlusion (CTO) percutaneous coronary intervention (PCI) advocates dual coronary injection, careful and structured review of the angiogram, and flexibility (1). Use of all crossing strategies (antegrade wire escalation [2], antegrade dissection re-entry [3-6], and the retrograde approach [7-10]) is encouraged (1), with initial and subsequent choices influenced by the CTO anatomic characteristics and the outcomes of the originally selected approach (1,11-18). Application of the hybrid approach to CTO PCI has been associated with good outcomes in U.S. and European registries, although CTO PCI outcomes in nonselected populations have been less optimal, with a success rate of approximately $60 \%$ (19). We examined a contemporary, multicenter CTO PCI registry to determine the techniques and outcomes of hybrid CTO PCI in a diverse group of patients and operators on 2 continents.

SEE PAGE 1336

\section{METHODS}

We analyzed the clinical, angiographic, and procedural characteristics of 3,122 CTO PCIs performed in 3,055 patients enrolled in the PROGRESS CTO (Prospective Global Registry for the Study of Chronic Total Occlusion Intervention; NCT02061436) registry between January 2012 and November 2017 at 18 U.S., 1 European, and 1 Russian center (Online Appendix). Some centers enrolled patients during only part of the study period because of participation in other studies. The study was approved by the Institutional Review Board of each center.

DEFINITIONS. Coronary CTOs were defined as coronary lesions with TIMI (Thrombolysis In Myocardial Infarction) flow grade 0 of at least 3 months' duration. Estimation of the duration of occlusion was clinical, based on the first onset of angina, history of myocardial infarction (MI) in the target vessel territory, or comparison with a prior angiogram. Calcification was assessed by angiography as mild (spots), moderate (involving $\leq 50 \%$ of the reference lesion diameter), or severe (involving $>50 \%$ of the reference lesion diameter). Moderate proximal vessel tortuosity was defined as the presence of at least 2 bends $>70^{\circ}$ or 1 bend $>90^{\circ}$ and severe tortuosity as 2 bends $>90^{\circ}$ or 1 bend $>120^{\circ}$ in the CTO vessel. Blunt or no stump was defined as lack of tapering or lack of a funnel shape at the proximal cap. Interventional collateral vessels were defined as collateral vessels considered amenable to crossing by a guidewire and a

Minnesota; ${ }^{\mathrm{p}}$ Meshalkin Siberian Federal Biomedical Research Center, Ministry of Health of Russian Federation, Novosibirsk, Russian Federation; ${ }^{\mathrm{q}}$ Korgialeneio-Benakeio Hellenic Red Cross General Hospital of Athens, Athens, Greece; and the ${ }^{\mathrm{r}}$ VA North Texas Health Care System and University of Texas Southwestern Medical Center, Dallas, Texas. The PROGRESS CTO registry has received support from the Abbott Northwestern Hospital Foundation. Dr. Karmpaliotis has received speaking honoraria from Abbott Vascular, Boston Scientific, Medtronic, and Vascular Solutions. Dr. Alaswad has received consulting fees from Terumo and Boston Scientific and is a consultant (without financial remuneration) for Abbott Laboratories. Dr. Jaffer is a consultant for Abbott Vascular and Boston Scientific and has received research grants from Canon, Siemens, and the National Institutes of Health. Dr. Yeh has received a Career Development Award (1K23HL118138) from the National Heart, Lung, and Blood Institute. Dr. Patel is a member of the Speakers Bureau for AstraZeneca. Dr. Mahmud has received consulting fees from Medtronic and Corindus; speaking fees from Medtronic, Corindus, and Abbott Vascular; educational program fees from Abbott Vascular; and clinical events committee fees from St. Jude Medical. Dr. Burke has received consulting and speaking honoraria from Abbott Vascular and Boston Scientific. Dr. Wyman has received honoraria and consulting and speaking fees from Boston Scientific, Abbott Vascular, and Asahi Intecc USA, Inc. Dr. Kandzari has received research and grant support and consulting honoraria from Boston Scientific and Medtronic Cardiovascular and research and grant support from Abbott Vascular. Dr. Garcia has received consulting fees from Medtronic. Dr. Moses is a consultant to Boston Scientific and Abiomed. Dr. Lembo is a member of the Speakers Bureau for Medtronic; and advisory boards for Abbott Vascular and Medtronic. Dr. Parikh is a member of the Speakers Bureau for Abbott Vascular, Medtronic, Cardiovascular Systems Inc., Boston Scientific, and Trireme; and on the advisory boards for Medtronic, Abbott Vascular, and Philips. Dr. Kirtane has received institutional research grants to Columbia University from Boston Scientific, Medtronic, Abbott Vascular, Abiomed, St. Jude Medical, Vascular Dynamics, GlaxoSmithKline, and Eli Lilly. Dr. Ali has received consulting fees and honoraria from St. Jude Medical and AstraZeneca Pharmaceuticals; has ownership interest, partnership, or principal interest in Shockwave Medical and VitaBx; and has received research grants from Medtronic and St. Jude Medical. Dr. Rangan has received research grants from InfraReDx and Spectranetics. Dr. Banerjee has received research grants from Gilead and The Medicines Company; has received consulting and speaking honoraria from Covidien and Medtronic; has ownership in MDCARE Global (spouse); and has intellectual property in HygeiaTel. Dr. Brilakis has received consulting and speaking honoraria from Abbott Vascular, ACIST Medical Systems, Amgen, Asahi Intecc USA, Inc., Cardiovascular Systems Inc., Elsevier, GE Healthcare, Medicure, Medtronic, and Nitiloop; has received research support from Boston Scientific and Osprey; is a member of the board of directors of Cardiovascular Innovations Foundation; and is a member of the board of trustees of the Society of Cardiovascular Angiography and Interventions. All other authors have reported that they have no relationships relevant to the contents of this paper to disclose. 
microcatheter by the operator. A procedure was defined as "retrograde" if an attempt was made to cross the lesion through a collateral vessel or bypass graft supplying the target vessel distal to the lesion; if not, the procedure was classified as "antegrade only." Antegrade dissection re-entry was defined as antegrade PCI during which a guidewire was intentionally introduced into the subintimal space proximal to the lesion, or re-entry into the distal true lumen was attempted following intentional or inadvertent subintimal guidewire crossing.

Technical success was defined as successful CTO revascularization with achievement of $<30 \%$ residual diameter stenosis within the treated segment and restoration of TIMI antegrade flow grade 3. Procedural success was defined as the achievement of technical success without any in-hospital complications. Inhospital major adverse cardiac events (MACE) included any of the following adverse events before hospital discharge: death, MI, recurrent symptoms requiring urgent repeat target vessel revascularization with PCI or coronary artery bypass graft (CABG) surgery, tamponade requiring either pericardiocentesis or surgery, and stroke. MI was defined using the third universal definition of MI (type 4a MI) (20). Major bleeding was defined as bleeding causing reduction in hemoglobin $>3 \mathrm{~g} / \mathrm{dl}$ or bleeding requiring transfusion or surgical intervention. The J-CTO (Multicenter Chronic Total Occlusion Registry of Japan) score was calculated as described by Morino et al. (21), the PROGRESS CTO score as described by Christopoulos et al. (22), and the PROGRESS CTO complications score as described by Danek et al. (23).

STATISTICAL ANALYSIS. Categorical variables were expressed as percentages and were compared using Pearson's chi-square test or the Fisher exact test. Continuous variables are presented as mean \pm SD or as median (interquartile range [IQR]) unless otherwise specified and were compared using the Student's $t$-test and 1-way analysis of variance for normally distributed variables; the Wilcoxon rank sum test and the Kruskal-Wallis test were applied for nonparametric continuous variables as appropriate. Multivariate logistic regression with stepwise backward elimination was performed to examine the independent association between annual CTO PCI volume and procedural outcomes (procedural success and in-hospital MACE). Variables with univariate associations in the present study $(\mathrm{p}<0.05$ ) were entered into the model, as well as variables that have been previously linked with procedural outcomes of CTO PCI, including age, smoking, peripheral arterial disease, chronic lung disease, history of MI, stroke,

\begin{tabular}{|c|c|c|c|c|}
\hline & $\begin{array}{c}\text { Overall } \\
(\mathbf{N}=\mathbf{3}, 055)\end{array}$ & $\begin{array}{c}\text { Technical } \\
\text { Success } \\
(n=2,657)\end{array}$ & $\begin{array}{c}\text { Technical } \\
\text { Failure } \\
(n=398)\end{array}$ & p Value \\
\hline Age (yrs) & $64.80 \pm 10.09$ & $64.6 \pm 10.15$ & $66.01 \pm 9.63$ & 0.0141 \\
\hline Male & 85.25 & 84.69 & 88.95 & 0.0378 \\
\hline BMI $\left(\mathrm{kg} / \mathrm{m}^{2}\right)$ & $30.60 \pm 6.14$ & $30.50 \pm 6.15$ & $31.20 \pm 6.02$ & 0.0666 \\
\hline Smoking (current) & 26.01 & 25.37 & 30.27 & 0.0561 \\
\hline Diabetes & 43.02 & 43.53 & 39.65 & 0.1758 \\
\hline Dyslipidemia & 92.20 & 92.11 & 92.75 & 0.6781 \\
\hline Hypertension & 90.26 & 89.61 & 94.49 & 0.0044 \\
\hline Family history of CAD & 33.35 & 33.44 & 32.80 & 0.8423 \\
\hline CCS angina classification & & & & 0.4771 \\
\hline Class $\leq 1$ & 11.44 & 11.64 & 10.15 & \\
\hline Class $\geq 2$ & 88.56 & 88.36 & 89.85 & \\
\hline $\begin{array}{c}\text { Myocardial viability } \\
\text { performed }\end{array}$ & 24.99 & 24.28 & 29.32 & 0.0783 \\
\hline Prior MI & 46.00 & 44.82 & 53.75 & 0.0023 \\
\hline Heart failure & 30.56 & 29.71 & 36.25 & 0.0159 \\
\hline $\begin{array}{r}\text { Prior valve surgery } \\
\text { or procedure }\end{array}$ & 3.17 & 3.06 & 3.89 & 0.4210 \\
\hline Prior PCl & 65.29 & 64.49 & 70.62 & 0.0180 \\
\hline Prior CABG surgery & 32.49 & 31.28 & 40.68 & 0.0003 \\
\hline Baseline creatinine $(\mathrm{mg} / \mathrm{dl})$ & $1.01(0.89-1.22)$ & $1.01(0.89-1.21)$ & $1.07(0.90-1.27)$ & 0.1301 \\
\hline Currently on dialysis & 2.67 & 2.50 & 3.80 & 0.1633 \\
\hline Prior CVD & 11.70 & 11.51 & 12.90 & 0.4567 \\
\hline Prior PAD & 15.02 & 14.53 & 18.29 & 0.0709 \\
\hline Chronic lung disease & 14.20 & 13.80 & 16.81 & 0.1386 \\
\hline Left ventricular EF (\%) & $54(42-60)$ & $55(44-60)$ & $50(40-60)$ & 0.0357 \\
\hline
\end{tabular}

PCI or CABG surgery, left ventricular ejection fraction, СTO target vessel, multiple СТО vessels treated during the same procedure, and CTO PCI only. All statistical analyses were performed using JMP version 13.0 (SAS Institute, Cary, North Carolina). A 2-sided $\mathrm{p}$ value of 0.05 was considered to indicate statistical significance.

\section{RESULTS}

CLINICAL AND ANGIOGRAPHIC CHARACTERISTICS. The baseline clinical features of the study population are summarized in Table 1. Compared with patients who had CTO PCI fail, patients who had successful CTO PCI were younger and less likely to be men and to have hypertension. They were also less likely to have had an MI, congestive heart failure, prior CABG surgery, and prior PCI and had higher left ventricular ejection fraction. Most patients (88.56\%) were symptomatic, having at least Canadian Cardiovascular Society (CCS) angina classification class II 


\begin{tabular}{|c|c|c|c|c|}
\hline & $\begin{array}{c}\text { Overall } \\
(\mathrm{N}=\mathbf{3 , 1 2 2})\end{array}$ & $\begin{array}{c}\text { Technical } \\
\text { Success } \\
(\mathbf{n}=\mathbf{2 , 7 1 1 )} \\
\end{array}$ & $\begin{array}{c}\text { Technical } \\
\text { Failure } \\
(n=411) \\
\end{array}$ & p Value \\
\hline Target vessel & & & & 0.0640 \\
\hline RCA & 55.22 & 54.93 & 57.14 & \\
\hline LAD & 23.81 & 24.57 & 18.80 & \\
\hline LCx & 19.91 & 19.47 & 22.81 & \\
\hline Other & 1.06 & 1.03 & 1.25 & \\
\hline CTO length (mm) & $33.99 \pm 24.16$ & $33.43 \pm 24.14$ & $37.80 \pm 23.99$ & 0.0030 \\
\hline Vessel diameter $(\mathrm{mm})$ & $2.85 \pm 0.51$ & $2.86 \pm 0.51$ & $2.81 \pm 0.47$ & 0.1383 \\
\hline Proximal cap ambiguity & 35.06 & 31.98 & 53.97 & $<0.0001$ \\
\hline Side branch at proximal cap & 49.91 & 47.56 & 64.14 & $<0.0001$ \\
\hline Blunt stump/no stump & 53.69 & 50.61 & 72.55 & $<0.0001$ \\
\hline Interventional collateral vessels & 56.72 & 58.80 & 44.19 & $<0.0001$ \\
\hline Moderate/severe calcification & 54.23 & 52.30 & 67.02 & $<0.0001$ \\
\hline Moderate/severe tortuosity & 34.96 & 33.43 & 45.21 & $<0.0001$ \\
\hline In-stent restenosis & 16.61 & 16.13 & 19.68 & 0.0878 \\
\hline Previously failed CTO PCI & 20.20 & 19.21 & 26.70 & 0.0005 \\
\hline J-CTO score & $2.43 \pm 1.30$ & $2.34 \pm 1.29$ & $3.07 \pm 1.13$ & $<0.0001$ \\
\hline PROGRESS CTO score & $1.32 \pm 1.03$ & $1.25 \pm 1.01$ & $1.77 \pm 1.01$ & $<0.0001$ \\
\hline $\begin{array}{l}\text { PROGRESS CTO } \\
\text { complication score }\end{array}$ & $3.07 \pm 1.93$ & $3.00 \pm 1.91$ & $3.54 \pm 1.97$ & $<0.0001$ \\
\hline \multicolumn{5}{|c|}{$\begin{array}{l}\text { Values are } \% \text { or mean } \pm \text { SD. } \\
\text { CTO = chronic total occlusion; J-CTO = Multicenter Chronic Total Occlusion Registry of Japan; LAD = left } \\
\text { anterior descending coronary artery; } L C X=\text { left circumflex coronary artery; } L M=\text { left main segment; PCI } \\
\text { percutaneous coronary intervention; PROGRESS CTO = Prospective Global Registry for the Study of Chronic Total } \\
\text { Occlusion Intervention; RCA = right coronary artery. }\end{array}$} \\
\hline
\end{tabular}

(CCS class II, 24.97\%; CCS class III, 53.93\%; CCS class IV , 9.65\%), and most had stable $(64.33 \%)$ or unstable (18.20\%) angina.

The angiographic characteristics of the study lesions are presented in Table 2. The CTO target lesions were located in the right coronary artery (55.22\%), left anterior descending coronary artery (23.81\%), and left circumflex coronary artery (19.91\%). Failed CTO PCI was associated with longer lesion length $(33.4 \pm 24.1$ mm vs. $37.9 \pm 24.0 \mathrm{~mm}$; $\mathrm{p}=0.0030$ ), proximal cap ambiguity (53.97\% vs. $31.98 \%$; p $<0.0001$ ), moderate to severe calcification ( $72.55 \%$ vs. $52.30 \%$; p $<0.0001)$, and tortuosity $(45.21 \%$ vs. $33.43 \%$; p $<0.0001)$ or previously failed recanalization attempt (26.70\% vs. $19.21 \%$; $p=0.0005)$. Failed CTO PCI cases also had higher J-CTO scores $(2.34 \pm 1.29$ vs. $3.07 \pm 1.13$; $\mathrm{p}<0.0001)$, PROGRESS CTO scores $(1.25 \pm 1.01 \mathrm{vs}$. $1.77 \pm 1.13$; $\mathrm{p}<0.0001)$, and PROGRESS CTO complications scores $(3.00 \pm 1.91$ vs. $3.54 \pm 1.97 ; \mathrm{p}<0.0001)$.

PROCEDURAL OUTCOMES OF THE HYBRID APPROACH. Overall technical and procedural success was $87 \%$ and $85 \%$, respectively, and the inhospital major complications rate was $3.0 \%$. The baseline technical and procedural characteristics are presented in Tables 3 and 4. Antegrade wire escalation was the most commonly used initial approach
TABLE 3 Techniques Used for Chronic Total Occlusion Percutaneous Coronary Intervention in the Study Patients

\begin{tabular}{|c|c|c|c|c|}
\hline & $\begin{array}{c}\text { Overall } \\
(\mathrm{N}=\mathbf{3 , 1 2 2})\end{array}$ & $\begin{array}{c}\text { Technical } \\
\text { Success } \\
(\mathbf{n}=\mathbf{2 , 7 1 1 )}\end{array}$ & $\begin{array}{c}\text { Technical } \\
\text { Failure } \\
(\mathrm{n}=\mathbf{4 1 1})\end{array}$ & p Value \\
\hline \multicolumn{5}{|l|}{ Crossing strategies used } \\
\hline AWE & 81.77 & 81.15 & 85.89 & 0.0204 \\
\hline ADR & 31.68 & 29.69 & 44.77 & $<0.0001$ \\
\hline Retrograde & 38.57 & 35.96 & 55.72 & $<0.0001$ \\
\hline \multicolumn{2}{|l|}{ First crossing strategy } & & & 0.0124 \\
\hline AWE & 75.36 & 75.80 & 72.51 & \\
\hline ADR & 8.39 & 8.67 & 6.57 & \\
\hline Retrograde & 16.24 & 15.53 & 20.92 & \\
\hline \multicolumn{2}{|l|}{ Final crossing strategy } & & & $<0.0001$ \\
\hline AWE & 45.89 & 51.95 & 5.24 & \\
\hline ADR & 18.95 & 20.96 & 5.49 & \\
\hline Retrograde & 23.97 & 27.09 & 2.99 & \\
\hline None & 11.19 & 0.00 & 86.28 & \\
\hline $\begin{array}{l}\text { Balloon-uncrossable } \\
\text { lesions }\end{array}$ & 10.62 & 10.21 & 29.37 & $<0.0001$ \\
\hline $\begin{array}{l}\text { Balloon-undilatable } \\
\text { lesions }\end{array}$ & 11.11 & 10.74 & 22.22 & 0.0349 \\
\hline \multicolumn{5}{|l|}{ Access site } \\
\hline Right femoral & 78.96 & 78.46 & 82.24 & 0.0798 \\
\hline Left femoral & 54.29 & 53.34 & 60.58 & 0.0060 \\
\hline Right radial & 32.48 & 33.12 & 28.22 & 0.0481 \\
\hline Left radial & 18.67 & 19.48 & 13.38 & 0.0031 \\
\hline Bifemoral approach & 51.35 & 50.42 & 57.42 & 0.0082 \\
\hline Biradial approach & 14.09 & 14.90 & 8.76 & 0.0009 \\
\hline \multicolumn{5}{|c|}{$\begin{array}{l}\text { Values are } \% \\
\qquad A D R=\text { antegrade dissection reentry; } A W E=\text { antegrade wire escalation. }\end{array}$} \\
\hline
\end{tabular}

(in 75\%), especially for lower complexity CTOs (J-CTO score $2.28 \pm 1.29$, PROGRESS CTO score $1.35 \pm 1.05$ ), whereas antegrade dissection re-entry (8\%; J-CTO score $2.86 \pm 1.16$, PROGRESS CTO score $1.50 \pm 1.07$ ) and the retrograde approach (16\%; J-CTO score $3.12 \pm$ 1.07, PROGRESS CTO score $1.33 \pm 0.96$ ) were used for more complex lesions $(p<0.0001)$. The initial approach was successful in $55 \%$ of patients, whereas $41 \%$ of patients underwent further attempts that were technically successful in 79\% (Figure 1).

The final successful crossing strategy was antegrade wire escalation (46\%), antegrade dissection reentry (19\%), and the retrograde approach $(24 \%)$. The success of antegrade wire escalation decreased with lesion complexity, as classified with the J-CTO score (easy [J-CTO score 0], 88\%; intermediate [J-CTO score 1], 72\%; difficult [J-CTO score 2], 51\%; and very difficult [J-CTO score $\geq 3], 32 \%$ to $17 \%$; $\mathrm{p}<0.0001)$ and the PROGRESS CTO score (55\%, 43\%, $42 \%, 39 \%$, and $43 \%$, respectively for scores of $0,1,2$, 3 , and $4 ; \mathrm{p}<0.0001)$. The retrograde approach was more commonly required for complex lesions, as classified by the J-CTO score (3\%, 9\%, 20\%, and 35\% to $44 \%$, respectively for J-CTO scores of $0,1,2$, 


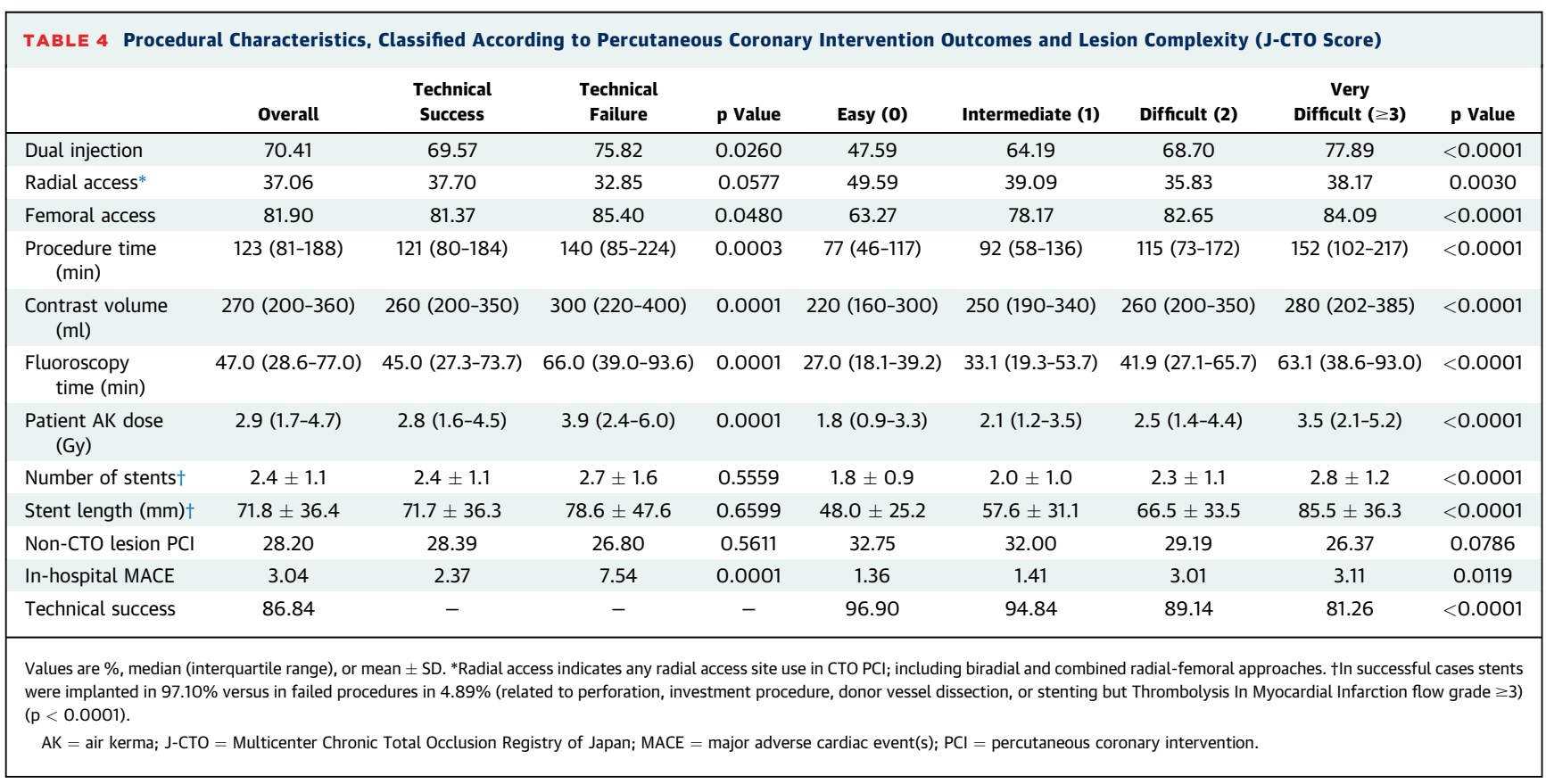

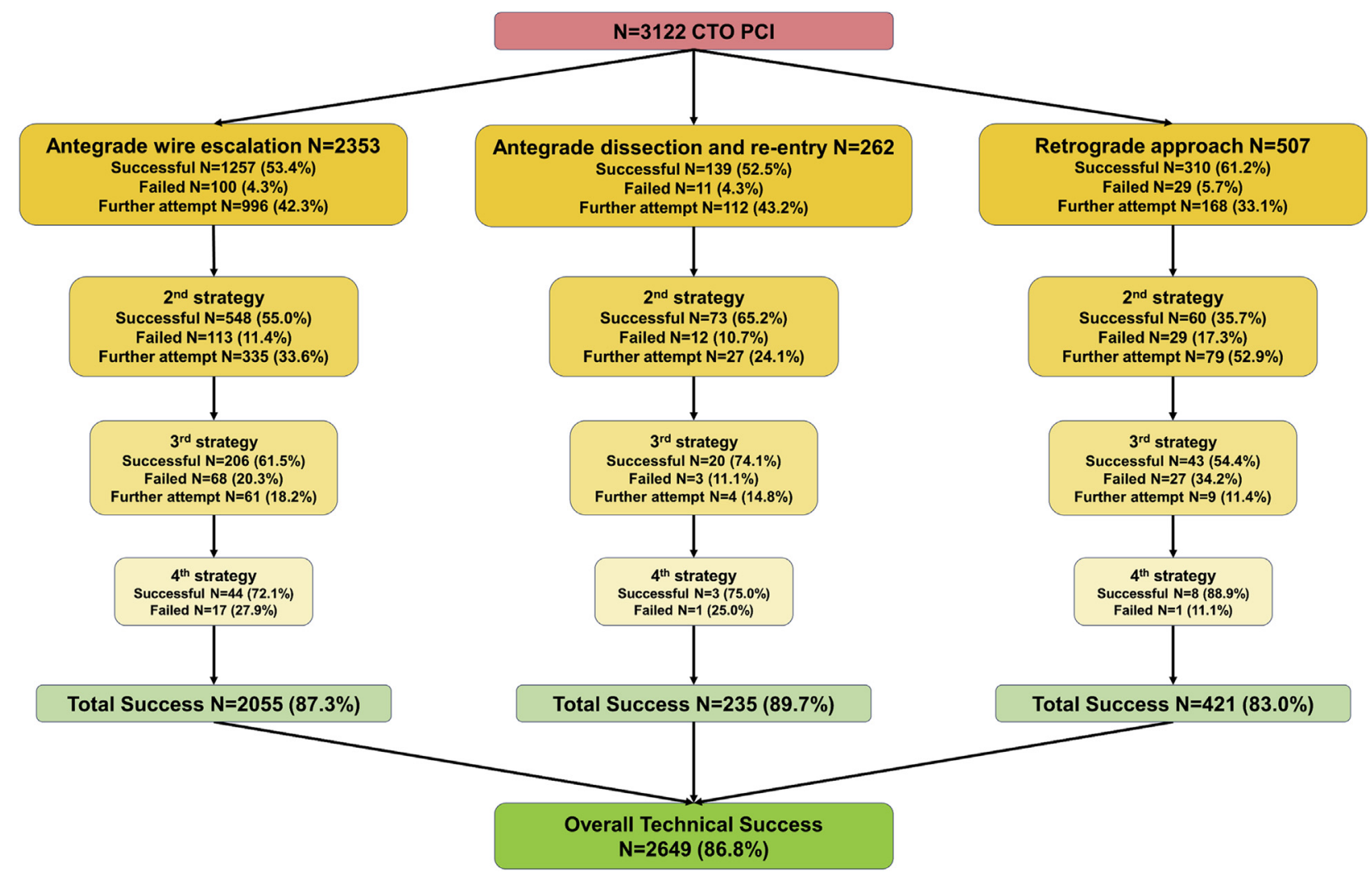

Sequence of chronic total occlusion (СTO) crossing techniques used in the study patients and associated technical success. PCI = percutaneous coronary intervention. 
FIGURE 2 Technical Success and Crossing Strategy Use According to J-CTO Score and the PROGRESS CTO Score

\section{A}

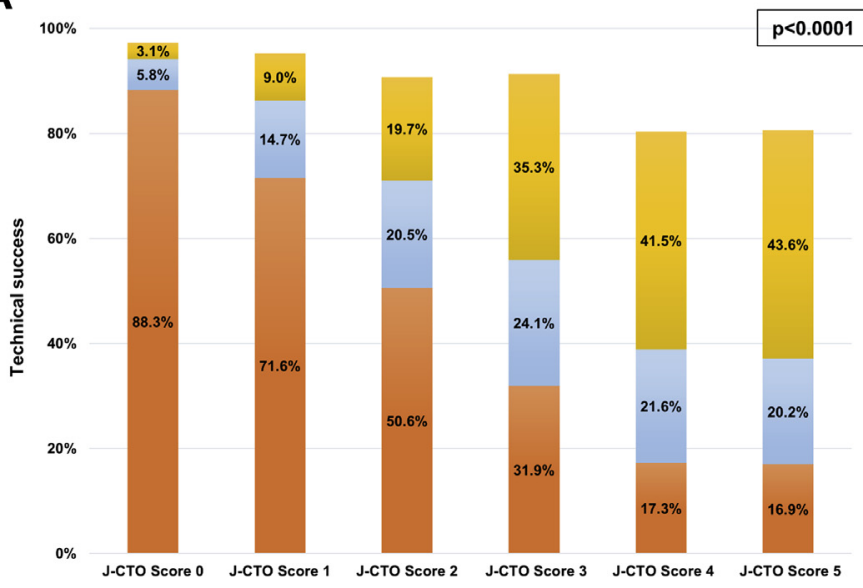

B

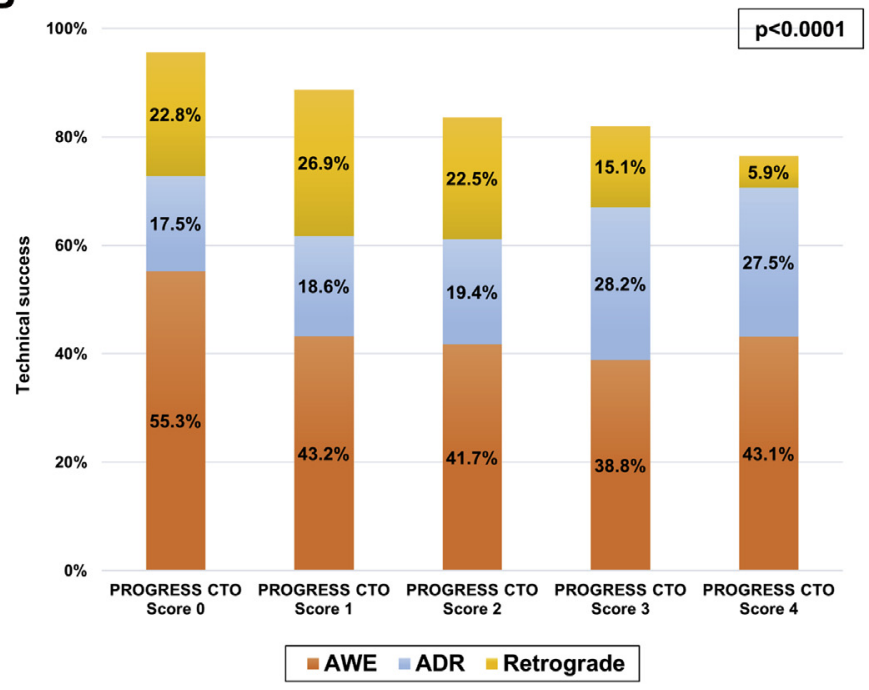

Impact of chronic total occlusion (СTO) lesion complexity, as assessed by the J-CTO score (A) and PROGRESS CTO score (B) on technical success and use of various crossing strategies. $A D R=$ antegrade dissection re-entry; $A W E$ = antegrade wire escalation; $\mathrm{J}-\mathrm{CTO}=$ Multicenter Chronic Total Occlusion Registry of Japan; PROGRESS CTO = Prospective Global Registry for the Study of Chronic Total Occlusion Intervention.

and $\geq 3$; p $<0.0001$ ) but less frequently in lesions with higher PROGRESS CTO score $(23 \%, 27 \%, 23 \%$, $15 \%$, and 6\%; $\mathrm{p}<0.0001$ ) (Figures $2 \mathrm{~A}$ and $2 \mathrm{~B}$ ).

Dual injection was used in $70 \%$ of all cases and was more frequent in failed interventions (76\% vs. $70 \%$; $\mathrm{p}=0.026)$ and in complex lesions with high J-CTO scores (48\% vs. 78\%; p < 0.0001). Radial access was used in $37 \%$ overall, with a biradial approach in $14 \%$ and in combination with a femoral approach in $20 \%$ of cases. Use of radial access was lower with increasing lesion complexity (easy, 50\%; intermediate, 39\%; difficult, $36 \%$; very difficult, $38 \%$; $\mathrm{p}=0.003$ ), whereas the frequency of femoral $(63 \%, 78 \%, 83 \%$, and $84 \%$; $\mathrm{p}<0.0001)$ and bifemoral (28\%, 43\%, 51\%, and 57\%; $\mathrm{p}<0.0001)$ approaches increased with increasing lesion complexity. Median contrast volume, air kerma radiation dose, and procedural and fluoroscopy time were $270 \mathrm{ml}$ (IQR: 200 to $360 \mathrm{ml}$ ), $2.9 \mathrm{~Gy}$ (IQR: 1.7 to $4.7 \mathrm{~Gy}$ ), and $123 \mathrm{~min}$ (IQR: 81 to $188 \mathrm{~min}$ ) and $47.0 \mathrm{~min}$ (IQR: 28.6 to $77.0 \mathrm{~min}$ ), respectively, and were higher for more complex lesions (Table 4). Less complex lesions required fewer stents $(p<0.0001)$, but the frequency of non-CTO PCI was higher in those groups and decreased with increasing lesion complexity $(\mathrm{p}=0.08)$.

The procedural success and annual CTO PCI volume at the participating sites are shown in Online Figure 1. Higher median annually performed CTO PCI per center was associated with higher procedural success in both univariate and multivariate analysis (Figure 3) but not in-hospital MACE.

The incidence of in-hospital MACE was 3.04\% (death, 0.85\%; acute MI, 1.08\%; stroke, 0.26\%; emergency CABG surgery, $0.16 \%$; urgent repeat PCI, $0.36 \%$; and pericardial tamponade, $0.85 \%$ ) and increased with increasing lesion complexity (Table 4). The prevalence of in-hospital MACE was higher in failed procedures (7.54\% vs. $2.37 \%$; p < 0.0001) and with more complex crossing techniques: antegrade wire escalation, antegrade dissection re-entry, or retrograde crossing (1.09\% vs. $2.96 \%$ vs. $5.61 \%$; p < 0.0001). Use of the retrograde approach was associated with higher incidence of complications, as shown in Figure 4. Median length of hospital stay was significantly higher in patients with versus without in-hospital MACE (6 days [IQR: 2 to 9 days] vs. 1 day [IQR: 1 to 2 days]); $\mathrm{p}<0.0001)$.

\section{DISCUSSION}

To the best of our knowledge, this is the largest study reported to date on CTO PCI using the hybrid approach, demonstrating a high technical success rate $(88 \%)$ with an acceptable major complication rate (3.0\%). These outcomes were achieved despite high lesion complexity and relatively low success of the initially selected CTO crossing strategy (55\%) (Figure 5).

Previous smaller studies have provided similarly encouraging results. In an earlier report from the PROGRESS CTO registry from 11 U.S. centers, technical success was $91 \%$ and in-hospital MACE was $1.7 \%$ (11). Wilson et al. (17) reported a $79 \%$ initial success rate among 1,156 patients from 7 centers enrolled in the UK Hybrid CTO Registry, with a 90\% 


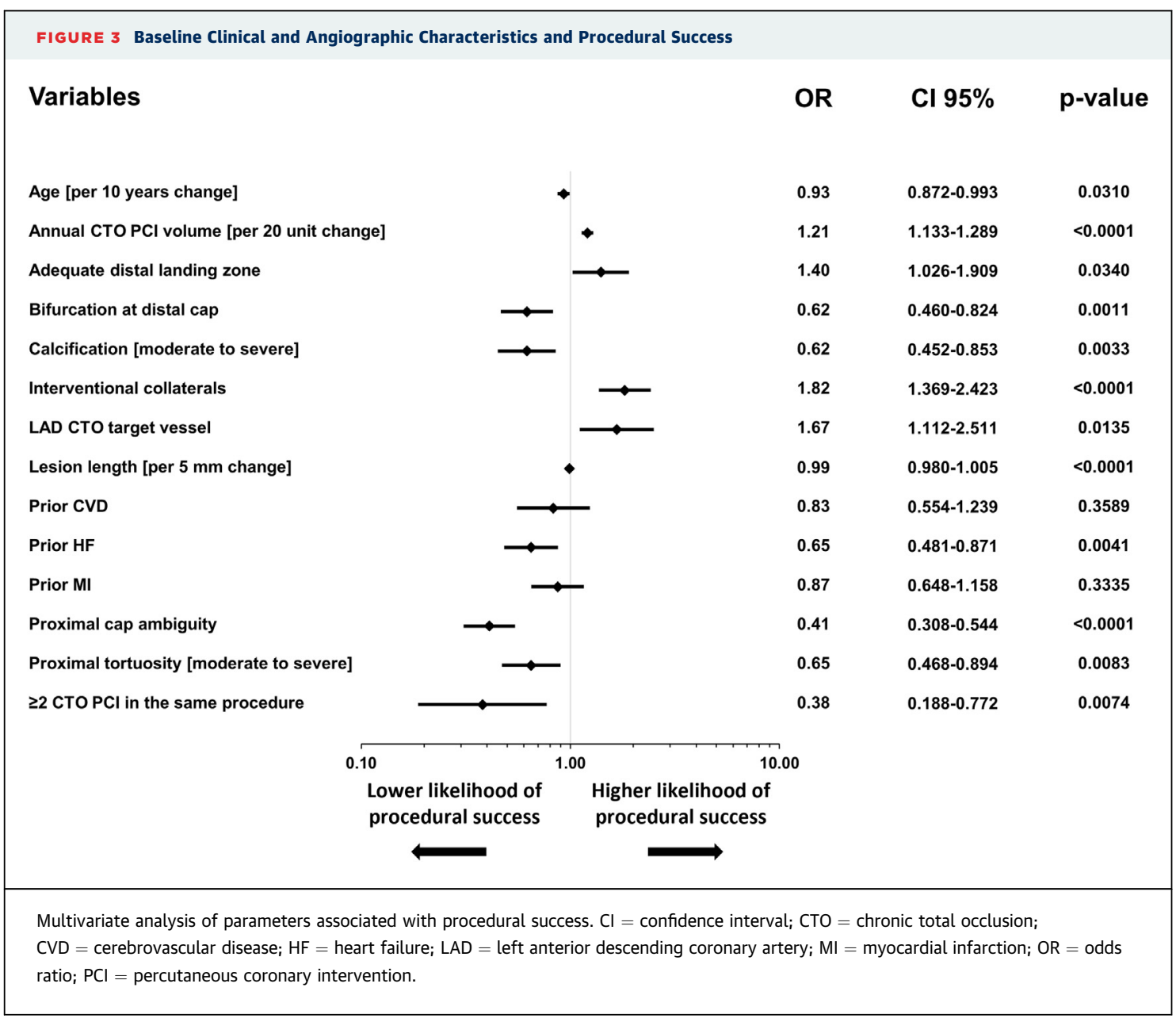

final technical success rate after repeat procedures. The RECHARGE (Registry of Crossboss and Hybrid Procedures in France, the Netherlands, Belgium, and United Kingdom) registry of 1,253 СTO interventions performed in 1,177 patients between 2014 and 2015 at 22 European centers reported an $86 \%$ procedural success rate and a $2.6 \%$ major in-hospital complication rate (18). Vo et al. (24) reported a singleoperator pilot study showing a rapid increase in procedural success despite the low initial CTO PCI experience. At 2 high-volume, experienced centers Pershad et al. (14) showed significant increase in technical (from $79.4 \%$ to $95.4 \%$; p $<0.001$ ) and procedural (from $77.9 \%$ to $88.3 \%$ ) success rates after implementation of the hybrid algorithm, compared with the pre-implementation period. Furthermore, the Hybrid Video Registry analyzed 194 videorecorded live case demonstrations reporting a high success rate $(92.8 \%)$, even in highly complex CTOs, with acceptable procedure time and contrast volume (25). As shown in prior studies, higher annual CTO PCI volume was independently associated with higher success rates, reflecting the importance of center and operator experience in optimizing outcomes, especially among complex lesion and patient subgroups (26).

In the present study, we found that technical and procedural success remained high, with reasonably low complication rates, despite expansion of the registry in recent years. Antegrade wire escalation was more commonly applied as the initial crossing approach (74\%) for less complex lesions (J-CTO score $2.24 \pm 1.24$, PROGRESS CTO score $1.32 \pm 0.87)$ and was the most common final crossing strategy (in approximately one-half of the cases). Antegrade dissection re-entry and retrograde techniques were more likely to be used as initial strategy in cases with complex anatomy (J-CTO scores $2.78 \pm 1.21$ and $3.32 \pm 0.98$, respectively; PROGRESS CTO scores $1.38 \pm 0.93$ and $2.00 \pm 0.89$, respectively) and were the final successful strategies in $22 \%$ and $28 \%$ of all cases, respectively.

Failure to cross with a guidewire was the most common reason for CTO PCI failure (in 86\%). In 
FIGURE 4 In-Hospital Major Complications Classified According to Final Successful Crossing Strategy

\section{AWE ADR Retrograde}

$8 \%$

$\%$

$p<0.0001$

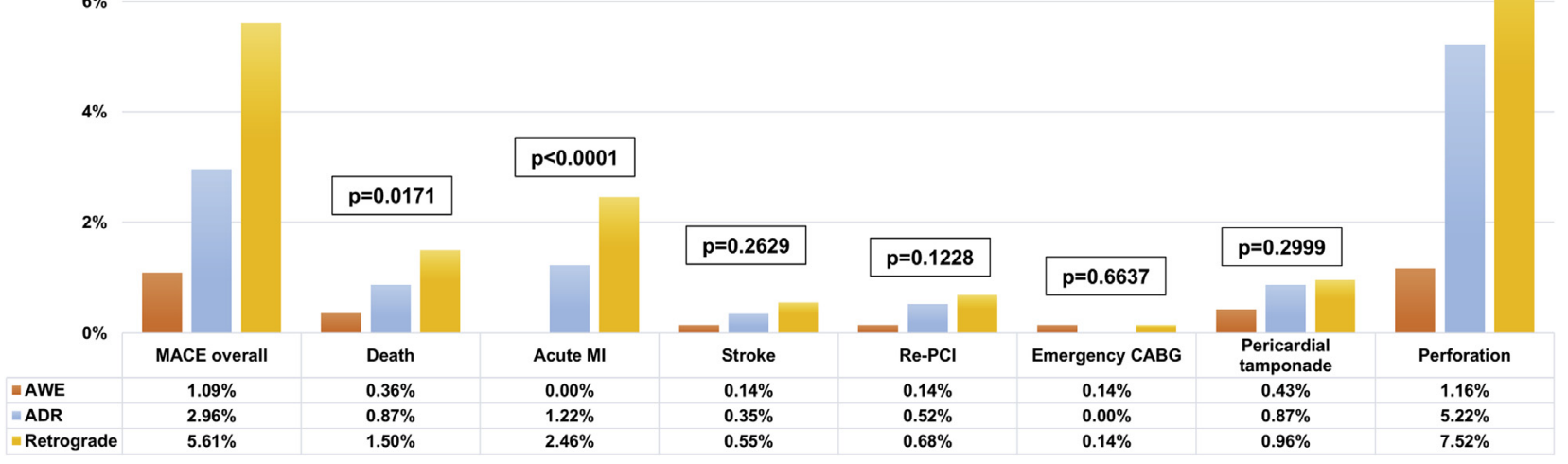

Use of the retrograde approach was associated with higher overall in-hospital major adverse cardiac events (MACE) and risk for perforation. ADR $=$ antegrade dissection and re-entry; $\mathrm{AWE}=$ antegrade wire escalation; $\mathrm{CABG}=$ coronary artery bypass graft; $\mathrm{MI}=$ myocardial infarction; $\mathrm{PCl}=$ percutaneous coronary intervention.

$13 \%$, the procedure failed despite successful guidewire crossing (Table 3) because of balloonundilatable lesions (3.9\%), inability to deliver stents $(2.3 \%)$, final TIMI flow grade $<3(1.3 \%)$, residual stenosis $>30 \%(1.0 \%)$, and procedure-related complications $(0.8 \%$; 1 patient with donor vessel thrombosis, 1 patient with aortocoronary dissection, and 1 procedure related death due to pericardial tamponade and subsequent cardiogenic shock). The presence of balloon-uncrossable (29.4\% vs. $10.2 \%$; $\mathrm{p}<0.0001)$ and balloon-undilatable lesions $(22.2 \%$ vs. $10.7 ; \mathrm{p}=0.0109$ ) was higher in the failed CTO PCI group, highlighting the need for CTO PCI operators to have experience in treating these and other complex lesions, such as severe calcification and bifurcations $(27,28)$.

The overall complication rate was $3 \%$, and complications occurred less frequently in technically successful procedures (2.2\% vs. $7.9 \%$; p $<0.0001)$. The risk for complications was higher in more complex lesions (easy [J-CTO score 0] $1.36 \%$ vs. very difficult [J-CTO score $\geq 3$ ] 3.11\%; $\mathrm{p}=0.01$ ) and with use of advanced crossing techniques (which were more commonly used for more complex lesions). This highlights the importance of weighing the risks and benefits of the procedure, both during discussions with patients and family (to determine whether CTO PCI should be done) and during the procedure itself: implementing more complex CTO crossing strategies (such as retrograde crossing via epicardial collateral vessels) may predispose to increased risk for complications, which may be justified in some patients because of significant potential benefit, but not in some others.

Despite the encouraging findings of our study and other contemporary registries, the success rates of CTO interventions in unselected patient cohorts remain low. Hannan et al. (29) (New York State PCI Registry, $n=4,030$ patients) reported a $61.3 \%$ success rate with a $1.07 \%$ complication rate (vs. $1.06 \%$ for non-CTO PCI cases, $\mathrm{p}=0.95$ ). Ramunddal et al. (30) showed a similarly low procedural success rate (54.2\%) among 6,442 patients undergoing CTO intervention in SCAAR (Swedish Coronary Angiography and Angioplasty Registry). Habara et al. (31) compared the acute outcomes of 3,229 CTO interventions among 56 high- and low-volume centers in Japan, showing a higher overall success rate at high-volume centers (90.6\% vs. $85.6 \%$; p < 0.001), without a significant difference in in-hospital MACE rate $(0.45 \%$ vs. $0.62 \% ; \mathrm{p}=0.35)$, attributed mostly to a higher antegrade success rate. Sharma et al. (32) showed that procedural outcomes of CTO interventions among operators who had received proctorship in using the hybrid approach were better (77.5\% vs. $62.1 \%$; p $<0.0001)$, especially in more complex cases (for J-CTO scores $\geq 2$, the corresponding rates were $70.7 \%$ and $49.5 \%$, respectively; $\mathrm{p}=0.0003$ ) than those who did not receive mentorship. Hence, CTO PCI should be performed by 
FIGURE 5 Clinical Case, Illustrating the Importance of Changing Crossing Strategy to Successfully Recanalize a Challenging Chronic Total Occlusion

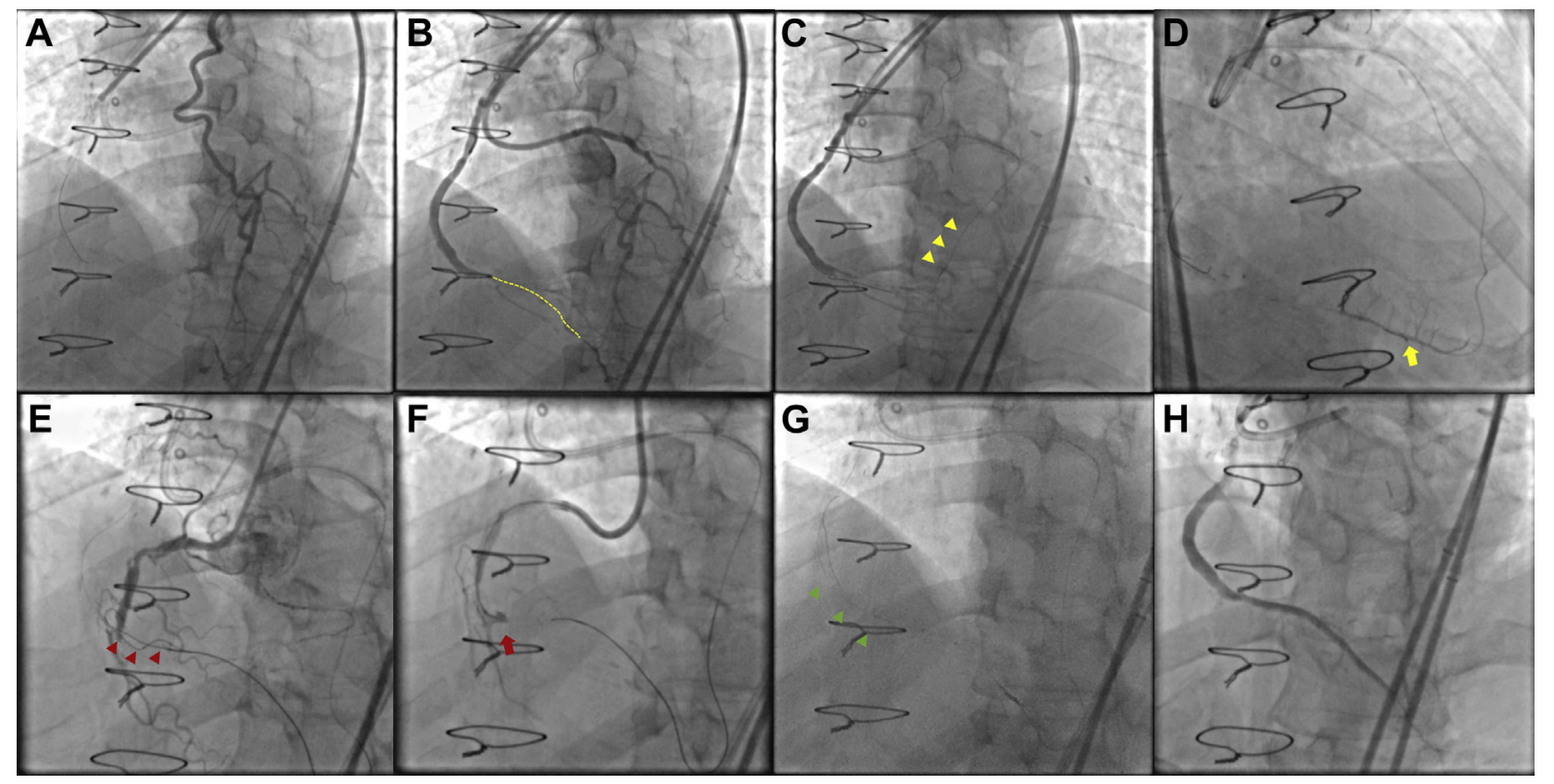

Percutaneous coronary intervention (PCI) of a distal right coronary artery (RCA) chronic total occlusion (CTO) in a patient with Canadian Cardiovascular Society class III angina and 4 prior failed CTO attempts and 2 prior coronary artery bypass graft surgeries. (A) Left internal mammary artery (LIMA) injection demonstrating septal and epicardial collateral channels from the left anterior descending coronary artery (LAD) to the RCA. (B) Triple coronary injection showing mild disease in the saphenous vein graft (SVG) to the RCA, distal RCA CTO immediately distal to the SVG anastomotic site, and mild disease in previously stented proximal and mid LAD along with competitive flow from the LIMA graft. (C) Multiple attempts for septal collateral crossing (using surfing and contrast guided techniques) succeeded in advancing a guidewire to the distal RCA, but a microcatheter could not be advanced over the guidewire. (D) Successful contrast-guided epicardial collateral crossing using a Suoh 03 guidewire over a Caravel microcatheter (Asahi Intecc, Nagoya, Japan). (E) Several attempts to advance the retrograde guidewire distal to the SVG anastomosis failed, despite using multiple guidewires. (F) Multiple attempts to recanalize the native RCA failed, as the antegrade guidewire could not be advanced distal to the SVG anastomosis. (G) The reverse controlled antegrade and retrograde tracking and dissection (CART) was successfully used to cross the CTO and advance the retrograde guidewire into the SVG-RCA, followed by guidewire externalization. (H) Final angiographic result after stent implantation. The patient had significant symptom alleviation.

experienced operators at dedicated centers to achieve optimal results.

STUDY LIMITATIONS. First, we did not have midand long-term follow-up of the study patients. Second, there was no core laboratory assessment of the study angiograms or clinical event adjudication. Third, the procedures were performed at dedicated, high-volume CTO centers by experienced operators, limiting the extrapolation to less experienced operators at low-volume centers.

\section{CONCLUSIONS}

CTO PCI can currently be achieved with high success and acceptable complication rates among various operators and patient populations in the United States and Europe, highlighting the need for developing more CTO PCI centers of excellence in order to achieve the best possible clinical outcomes in this challenging patient and lesion group.

ACKNOWLEDGMENTS Study data were collected and managed using Research Electronic Data Capture electronic data capture tools hosted at the Minneapolis Heart Institute Foundation. Research Electronic Data Capture is a secure, Web-based application designed to support data capture for research studies, providing: 1) an intuitive interface for validated data entry; 2) audit trails for tracking data manipulation and export procedures; 3) automated export procedures for seamless data downloads to common statistical packages; and 4) procedures for importing data from external sources.

ADDRESS FOR CORRESPONDENCE: Dr. Emmanouil S. Brilakis, Minneapolis Heart Institute, 920 East 28th Street, \#300, Minneapolis, Minnesota 55407. E-mail: esbrilakis@gmail.com. 


\section{PERSPECTIVES}

WHAT IS KNOWN? Coronary CTO can be challenging to recanalize, with success rates of approximately $60 \%$ in unselected, all-comer populations.

WHAT IS NEW? Application of the hybrid approach resulted in a high technical success rate $(87 \%)$ and an acceptable rate of major in-hospital complications (3\%) across a large number of sites and operators in the United States, Europe, and Russia. Changing crossing strategy was required in $41 \%$ of cases, with the final success strategy being antegrade wire escalation in $52 \%$, retrograde in $27 \%$, and antegrade dissection re-entry in $21 \%$.

WHAT IS NEXT? Bridging the gap between what is currently achieved and what can be achieved in СТО intervention should be a major focus of upcoming research and education efforts.

\section{REFERENCES}

1. Brilakis ES, Grantham JA, Rinfret $S$, et al. A percutaneous treatment algorithm for crossing coronary chronic total occlusions. J Am Coll Cardiol Intv 2012;5:367-79.

2. Rinfret $S$, Joyal D, Spratt JC, Buller CE. Chronic total occlusion percutaneous coronary intervention case selection and techniques for the antegrade-only operator. Catheter Cardiovasc Interv 2015;85:408-15.

3. Michael TT, Papayannis $A C$, Banerjee $S$, Brilakis ES. Subintimal dissection/reentry strategies in coronary chronic total occlusion interventions. Circ Cardiovasc Interv 2012;5:729-38.

4. Colombo A, Mikhail GW, Michev I, et al. Treating chronic total occlusions using subintimal tracking and reentry: the STAR technique. Catheter Cardiovasc Interv 2005;64:407-11.

5. Whitlow $\mathrm{PL}$, Burke $M N$, Lombardi $W L$, et al. Use of a novel crossing and re-entry system in coronary chronic total occlusions that have failed standard crossing techniques: results of the FASTCTOs (Facilitated Antegrade Steering Technique in Chronic Total Occlusions) trial. J Am Coll Cardiol Intv 2012;5:393-401.

6. Werner GS. The BridgePoint devices to facilitate recanalization of chronic total coronary occlusions through controlled subintimal reentry. Expert Rev Med Devices 2011;8:23-9.

7. Rathore $S$, Katoh $O$, Matsuo H, et al. Retrograde percutaneous recanalization of chronic total oc clusion of the coronary arteries: procedural outcomes and predictors of success in contemporary practice. Circ Cardiovasc Interv 2009;2:124-32.

8. Saito S. Different strategies of retrograde approach in coronary angioplasty for chronic total occlusion. Catheter Cardiovasc Interv 2008;71: 8-19.

9. Brilakis ES, Grantham JA, Thompson CA, et al, The retrograde approach to coronary artery chronic total occlusions: a practical approach. Catheter Cardiovasc Interv 2012;79:3-19.

10. Joyal D, Thompson CA, Grantham JA, Buller $\mathrm{CE}$, Rinfret $\mathrm{S}$. The retrograde technique for recanalization of chronic total occlusions: a stepby-step approach. J Am Coll Cardiol Intv 2012;5: $1-11$.
11. Christopoulos G, Karmpaliotis D, Alaswad K et al. Application and outcomes of a hybric approach to chronic total occlusion percutaneous coronary intervention in a contemporary multicenter US registry. Int J Cardiol 2015;198 $222-8$

12. Michael TT, Mogabgab $O$, Fuh E, et al. Application of the "hybrid approach" to chronic total occlusion interventions: a detailed procedural analysis. J Interv Cardiol 2014;27:36-43.

13. Christopoulos G, Menon RV, Karmpaliotis D, et al. Application of the "hybrid approach" to chronic total occlusions in patients with previous coronary artery bypass graft surgery (from Contemporary Multicenter US registry). Am J Cardiol 2014:113:1990-4

14. Pershad $A$, Eddin $M$, Girotra $S$, Cotugno $R$, Daniels D, Lombardi W. Validation and incrementa value of the hybrid algorithm for CTO PCl. Catheter Cardiovasc Interv 2014;84:654-9.

15. Sabbagh AE, Banerjee S, Brilakis ES. Illustration of the "hybrid" approach to chronic total occlusion crossing. Interventional Cardiology 2012;4 639-43.

16. Christopoulos G, Menon RV, Karmpaliotis D, et al. The efficacy and safety of the "hybrid" approach to coronary chronic total occlusions: insights from a contemporary multicenter US registry and comparison with prior studies. J Invasive Cardiol 2014;26:427-32.

17. Wilson WM, Walsh SJ, Yan AT, et al. Hybrid approach improves success of chronic total oc clusion angioplasty. Heart 2016;102:1486-93.

18. Maeremans J, Walsh $S$, Knaapen $P$, et al. The hybrid algorithm for treating chronic total occlusions in Europe: the RECHARGE registry. J Am Coll Cardiol 2016;68:1958-70.

19. Brilakis ES, Banerjee $S$, Karmpaliotis D, et al. Procedural outcomes of chronic total occlusion percutaneous coronary intervention: a report from the NCDR (National Cardiovascular Data Registry). J Am Coll Cardiol Intv 2015;8:245-53.

20. Thygesen K, Alpert JS, Jaffe AS, et al. Third universal definition of myocardial infarction. J Am Coll Cardiol 2012;60:1581-98.
21. Morino $Y$, Abe M, Morimoto $T$, et al. Predicting successful guidewire crossing through chronic total occlusion of native coronary lesions within 30 minutes: the J-CTO (Multicenter СТO Registry in Japan) score as a difficulty grading and time assessment tool. J Am Coll Cardiol Intv 2011;4: 213-21.

22. Christopoulos G, Kandzari DE, Yeh RW, et al. Development and validation of a novel scoring system for predicting technical success of chronic total occlusion percutaneous coronary interventions: the PROGRESS CTO (Prospective Global Registry for the Study of Chronic Total Occlusion Intervention) Score. J Am Coll Cardio Intv 2016;9:1-9.

23. Danek BA, Karatasakis A, Karmpaliotis D, et al. Development and validation of a scoring system for predicting periprocedural complications during percutaneous coronary interventions of chronic total occlusions: the Prospective Global Registry for the Study of Chronic Total Occlusion Intervention (PROGRESS CTO) complications score. J Am Heart Assoc 2016;5:e004272.

24. Vo MN, McCabe JM, Lombardi WL, Ducas J, Ravandi A, Brilakis ES. Adoption of the hybrid CTO approach by a single non-СTO operator: procedural and clinical outcomes. J Invasive Cardiol 2015;27:139-44.

25. Daniels DV, Banerjee $S$, Alaswad $K$, et at. Safety and efficacy of the hybrid approach in coronary chronic total occlusion percutaneous coronary intervention: the Hybrid Video Registry. Catheter Cardiovasc Interv 2018;91:175-9.

26. Michael TT, Karmpaliotis $D$, Brilakis ES, et al. Temporal trends of fluoroscopy time and contrast utilization in coronary chronic total occlusion revascularization: insights from a multicente united states registry. Catheter Cardiovasc Interv 2015;85:393-9.

27. Patel SM, Pokala NR, Menon RV, et al. Prevalence and treatment of "balloon-uncrossable" coronary chronic total occlusions. J Invasive Cardiol 2015;27:78-84.

28. Karacsonyi J, Karmpaliotis D, Alaswad K, et al. Prevalence, indications and management of balloon uncrossable chronic total occlusions: 
insights from a contemporary multicenter US registry. Catheter Cardiovasc Interv 2017;90: $12-20$.

29. Hannan EL, Zhong $Y$, Jacobs $A K$, et al. Patients With chronic total occlusions undergoing percutaneous coronary interventions: characteristics, success, and outcomes. Circ Cardiovasc Intery 2016;9:e003586.

30. Ramunddal $T$, Hoebers LP, Henriques JP, et al. Prognostic impact of chronic total occlusions: a report from SCAAR (Swedish Coronary
Angiography and Angioplasty Registry). J Am Coll Cardiol Intv 2016;9:1535-44.

31. Habara M, Tsuchikane $E$, Muramatsu $T$, et al. Comparison of percutaneous coronary intervention for chronic total occlusion outcome according to operator experience from the Japanese retrograde summit registry. Catheter Cardiovasc Intery 2016;87:1027-35.

32. Sharma V, Jadhav ST, Harcombe AA, et al. Impact of proctoring on success rates for percutaneous revascularisation of coronary chronic total occlusions. Open Heart 2015;2: e000228.

KEY WORDS chronic total occlusion, outcomes, percutaneous coronary intervention, techniques

APPENDIX For a list of centers participating in the present study and a supplemental figure, please see the online version of this paper. 



\title{
Az anterográd technikák szerepe a krónikus teljes koszorúér-elzáródás perkután revaszkularizációjában
}

\author{
Tajti Péter ${ }^{1,2}$, Ungi Imre \\ ${ }^{1}$ Szegedi Tudományegyetem, Invazív Kardiológiai Részleg, II. Sz. Belgyógyászati Klinika és \\ Kardiológiai Központ, Szeged \\ ${ }^{2}$ Minneapolis Heart Institute, Abbott Northwestern Hospital, Minneapolis, Minnesota, Egyesült Államok \\ Levelezési cím: \\ Dr. Ungi Imre PhD, Szegedi Tudományegyetem, Invazív Kardiológiai Részleg, II. sz. Belgyógyászati Klinika és Kardiológiai \\ Központ, 6725 Szeged, Semmelweis u. 6., e-mail: ungi.imre@gmail.com
}

\begin{abstract}
A krónikus teljes koszorúér-elzáródás perkután koronáriaintervenciója rohamos fejlődésen ment keresztül az elmúlt évtized alatt, amelynek következtében a dedikált CTO-centrumok beavatkozási sikeraránya jelentősen javult alacsony szövődményráta mellett. Sikeres CTO PCl a megfelelően megválasztott esetekben jelentős javuláshoz segíti a betegeket, ugyanakkor a CTO-revaszkularizációnak továbbra is a legnagyobb kihívása az okklúzió megnyitása. A széles körben alkalmazott technikák magukba foglalják az anterográd dróteszkaláció, az anterográd disszekció és re-entry, valamint a retrográd technikákat. Anterográd dróteszkaláció továbbra is a leggyakrabban alkalmazott, és legtöbb esetben sikeres technika, az anterográd disszekció re-entry és a retrográd technikákat föleg komplex léziók esetén alkalmazzuk. Cikkünk célja, hogy átfogó képet adjunk a jelenkori anterográd technikákról és eszközökről, amelyek elősegítik a vezetődrót átjutását az okklúzión.

Kulcsszavak: krónikus teljes koszorúér-elzáródás, perkután koronária-intervenció, stabil koronáriabetegség, komplex koronária-intervenció
\end{abstract}

The Role of Antegrade Techniques in Current Practice of Percutaneous Coronary Interventions for Chronic Total Occlusions

Chronic total occlusion (CTO) percutaneous coronary intervention (PCI) has been rapidly evolving with high success and acceptable complication rates currently being achieved at dedicated high-volume centers. Successful CTO PCI in appropriately selected patients can provide significant clinical benefits, however crossing the occlusion with a guidewire can be challenging. The following techniques can be used for CTO crossing: antegrade wire escalation, antegrade dissection/re-entry and the retrograde approach. Antegrade wire escalation remains the most frequently used technique and is the most common final successful technique, especially in less complex CTOs. Antegrade dissection re-entry and the retrograde approach are more technically demanding, but are often necessary to achieve crossing, in complex CTOs. In this manuscript, we provide a comprehensive overview of antegrade wire crossing of coronary CTOs.

Keywords: chronic total occlusion, percutaneous coronary intervention, stable coronary artery disease, complex coronary intervention

A krónikus teljes koszorúer-elzáródás (CTO) definíció szerint a koronária lumenének teljes (TIMI [Thrombolysis In Myocardial Infarction] flow 0) elzáródása, amely fennállásának időtartama minimum három hónap koronarográfiával, vagy annak hiányában a klinikai kép alapján alátámasztva. A CTO incidenciája 18-52\% közötti azon betegekben, akik diagnosztikus szívkatéterezésen esnek át koronáriabetegség tisztázása céljából
(1-4), ugyanakkor ezen betegek nagyobb része konzervatív gyógyszeres terápiában vagy mütéti revaszkularizációban részesül, csupán kis hányadukban végeznek perkután koronáriaintervenciót (PCI) (5). Ennek az alacsony aránynak lehetséges magyarázatai között szerepel a korlátozott intervenciós tapasztalat CTO PCI terén, a magasabb költségek, a relatíve hosszú beavatkozások miatti katéteres laborzsúfoltság, az átlagos in- 
tervenciókét meghaladó szövődményráta, és a továbbra is ellentmondásos kép a CTO-revaszkularizációnak klinikai hasznáról.

Az elmúlt években a CTO PCI technikája jelentős fejlődésen ment keresztül bizonyítva, hogy specializált centrumokban az esetek 85-90\%-ában sikeres revaszkularizáció érhető el alacsony periprocedurális kompli- káció rátával (3\%) (6-9). A legnagyobb technikai kihívást továbbra is a vezetődrót átjuttatása jelenti a distalis valódi lumen felé $(10,11)$, ami nem specializált centrumokban csak 50-60\%-os sikerarányt eredményez (4, 12, 13).

Az anginás panaszokkal, illetve szívelégtelenség tüneteivel élő betegek nagy száma miatt a krónikus teljes

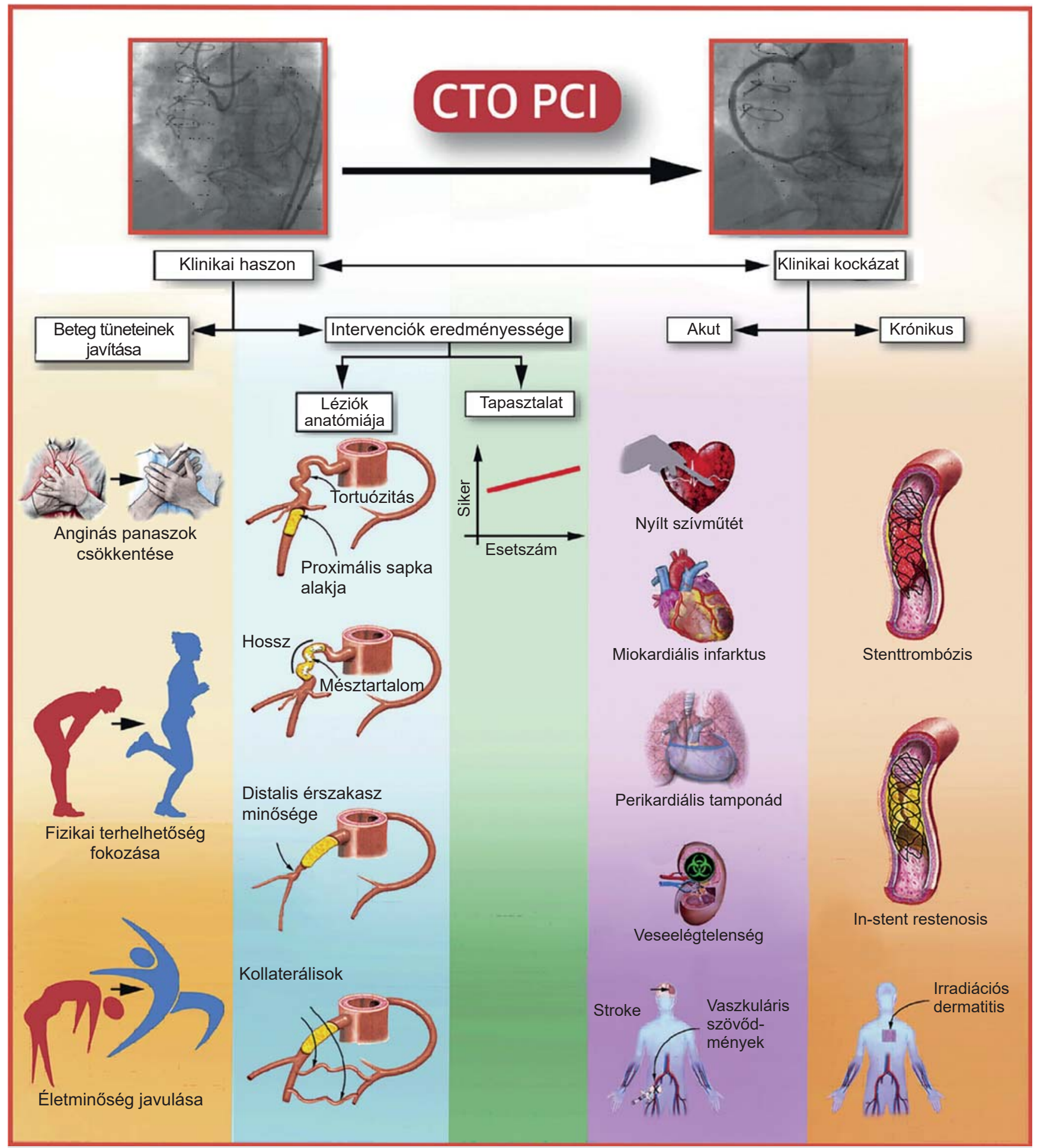

1. ÁBRA. Kockázat-haszon arány klinikai felbecslése a krónikus teljes koszorúér-elzáródások perkután koronária-intervenciója során (14) 
koszorúér-elzáródás perkután revaszkularizációja iránti igény emelkedik, amely több dedikált CTO-centrum kialakítását igényli hazánkban is. Az elmúlt évek technikai fejlődése elsősorban a jelenkori anterográd CTO rekanalizációs technikák elterjedését eredményezte, amelyek rutinszerú elsajátítása fontos sarokköve a sikeres CTO-program elindításának.

\section{Esetválasztás}

Egy adott centrum és operatőr felkészültségével arányos komplexitású esetek megválasztása kritikus az intervenció sikere és biztonsága szempontjából, így a kockázat-haszon arány mérlegelése az első fontos lépés az intervenciót megelőzően (1. ábra) (14). Az elzáródás $\mathrm{PCl}$-vel megoldhatóságának felmérését 4 fő kérdés köré kell csoportosítanunk:

- milyen klinikai javulás várható a sikeres CTO PCI elvégzését követően,

- mekkora a valószínüsége a beavatkozás sikerének az angiográfiás kép és a rendelkezésre álló eszköztár alapján,

- az operatőrök képzettsége megfelelő-e (2. ábra), valamint
- a beavatkozási szövődmények esélyének mérlegelése.

\section{CTO komplexitás}

Számos pontozási rendszert validáltak és közöltek az elmúlt évek alatt a CTO-intervenciók várható kimenetelének megítélésére (J-CTO Score [15], CL Score [16], PROGRESS CTO Score [17], ORA Score [18], RECHARGE Score [19], és az Ellis Score [20]). Ezek a pontrendszerek különbözö klinikai és angiográfiás faktorokat ötvöznek az eset komplexitásának és a beavatkozás nehézségének becslésére (1. táblázat) (15-21). Jelenleg a legáltalánosabban elterjedt és validált pontrendszer a J-CTO Score (22-24), amely segítségével megjósolható a vezetődrót distalis lumenbe juttatásának esélye 30 percen belül 5 alapvető paraméter figyelembevételével (lézióhossz $>20$ $\mathrm{mm}, 45^{\circ}$-os lézió tortuozitás, meszesedés angiográfiás jelei, a proximális sapka alakja [V-alakú vagy tompa], és korábbi sikertelen CTO intervenció).

A CTO pontrendszerek alkalmazása fontos lehet több szempontból is:

- felmérik a speciális rekanalizációs technikák szükségességet (anterográd disszekció és re-entry [ADR] és/vagy retrográd technikák) (3. ábra);

\section{TÁBLÁZAT. A jelenleg elérhető CTO pontozási rendszerek}

\begin{tabular}{|c|c|c|c|c|c|c|c|}
\hline Tényezök & $\begin{array}{c}\text { J-CTO } \\
\text { score (15) }\end{array}$ & $\begin{array}{c}\text { CL score } \\
\text { (16) }\end{array}$ & $\begin{array}{c}\text { PROGRESS } \\
\text { CTO score } \\
\text { (17) }\end{array}$ & $\begin{array}{c}\text { ORA score } \\
\text { (18) }\end{array}$ & $\begin{array}{l}\text { RECHARGE } \\
\text { score (19) }\end{array}$ & $\begin{array}{l}\text { Ellis core } \\
\text { (20) }\end{array}$ & $\begin{array}{c}\text { PROGRESS } \\
\text { CTO Comp- } \\
\text { lications } \\
\text { score (21) }\end{array}$ \\
\hline Esetszám (n) & 494 & 1,657 & 781 & 1,073 & 1,253 & 456 & 1589 \\
\hline Végpont & $\begin{array}{l}\text { Drót eszkala- } \\
\text { ció <30 min }\end{array}$ & $\begin{array}{l}\text { Angiográfiás } \\
\text { siker }\end{array}$ & $\begin{array}{l}\text { Angiográfiás } \\
\text { siker }\end{array}$ & $\begin{array}{l}\text { Angiográfiás } \\
\text { siker }\end{array}$ & $\begin{array}{l}\text { Angiográfiás } \\
\text { siker }\end{array}$ & $\begin{array}{l}\text { Angiográfiás } \\
\text { siker }\end{array}$ & $\begin{array}{l}\text { Periproce- } \\
\text { durális } \\
\text { komplikáciok }\end{array}$ \\
\hline Életkor (év) & - & - & - & $+(\geq 75)$ & $+(>65)$ & - & $+(>65)$ \\
\hline $\begin{array}{l}\text { Korábbi } \\
\text { CABG }\end{array}$ & - & + & - & - & + & - & - \\
\hline $\begin{array}{l}\text { Korábbi siker- } \\
\text { telen kísérlet }\end{array}$ & + & - & - & - & - & - & - \\
\hline $\begin{array}{l}\text { Proximális } \\
\text { sapka }\end{array}$ & $+($ Tompa $)$ & $+($ Tompa $)$ & + (Homályos) & + (Ostialis) & + & $\begin{array}{c}\text { (Homályos } \\
\text { ostialis })\end{array}$ & - \\
\hline Tortuózitás & $\begin{array}{c}+\left(>45^{\circ}\right. \\
\text { okkludált } \\
\text { Szegmentben })\end{array}$ & - & $\begin{array}{l}\text { + (okkludált } \\
\text { szegmenttöl } \\
\text { proximali- } \\
\text { san†) }\end{array}$ & - & + & + & - \\
\hline Meszesedés & + & + & - & - & + & + & - \\
\hline Lézió hossz & $+(\geq 20 \mathrm{~mm})$ & $+(\geq 20 \mathrm{~mm})$ & - & - & + & + & $+(>23 \mathrm{~mm})$ \\
\hline Okkludált ér & - & $+($ nem-LAD) & $+(\mathrm{LCX})$ & - & - & $\begin{array}{c}\text { + (Kedvezőt- } \\
\text { len distalis } \\
\text { érszakasz) }\end{array}$ & - \\
\hline $\begin{array}{l}\text { Kollaterálisok } \\
\text { minősége }\end{array}$ & - & - & $\begin{array}{c}+ \text { (Interven- } \\
\text { ciós })\end{array}$ & $\begin{array}{c}+ \text { Rentrop } \\
<2)\end{array}$ & - & + & - \\
\hline Egyéb & - & $\begin{array}{l}\text { Korábbi } \\
\text { miokardiális } \\
\text { infarktus }\end{array}$ & - & - & $\begin{array}{c}\text { BMI }>30, \text { nem } \\
\text { proximalis } \\
\text { lokáció }\end{array}$ & $\begin{array}{c}\text { CTO } \\
\text { intervenciós } \\
\text { tapasztalat }\end{array}$ & $\begin{array}{c}\text { Retrográd } \\
\text { technika } \\
\text { alkalmazása }\end{array}$ \\
\hline
\end{tabular}

†A CTO-tól proximalisan lévő érszakasznak minimum 2 görbülete a $70^{\circ}$-ot, vagy 1 görbülete a $90^{\circ}$-ot meghaladja.

BMI, body mass index; CABG, coronary artery bypass grafting; LAD, left anterior descending artery; LCX, circumflex artery. 


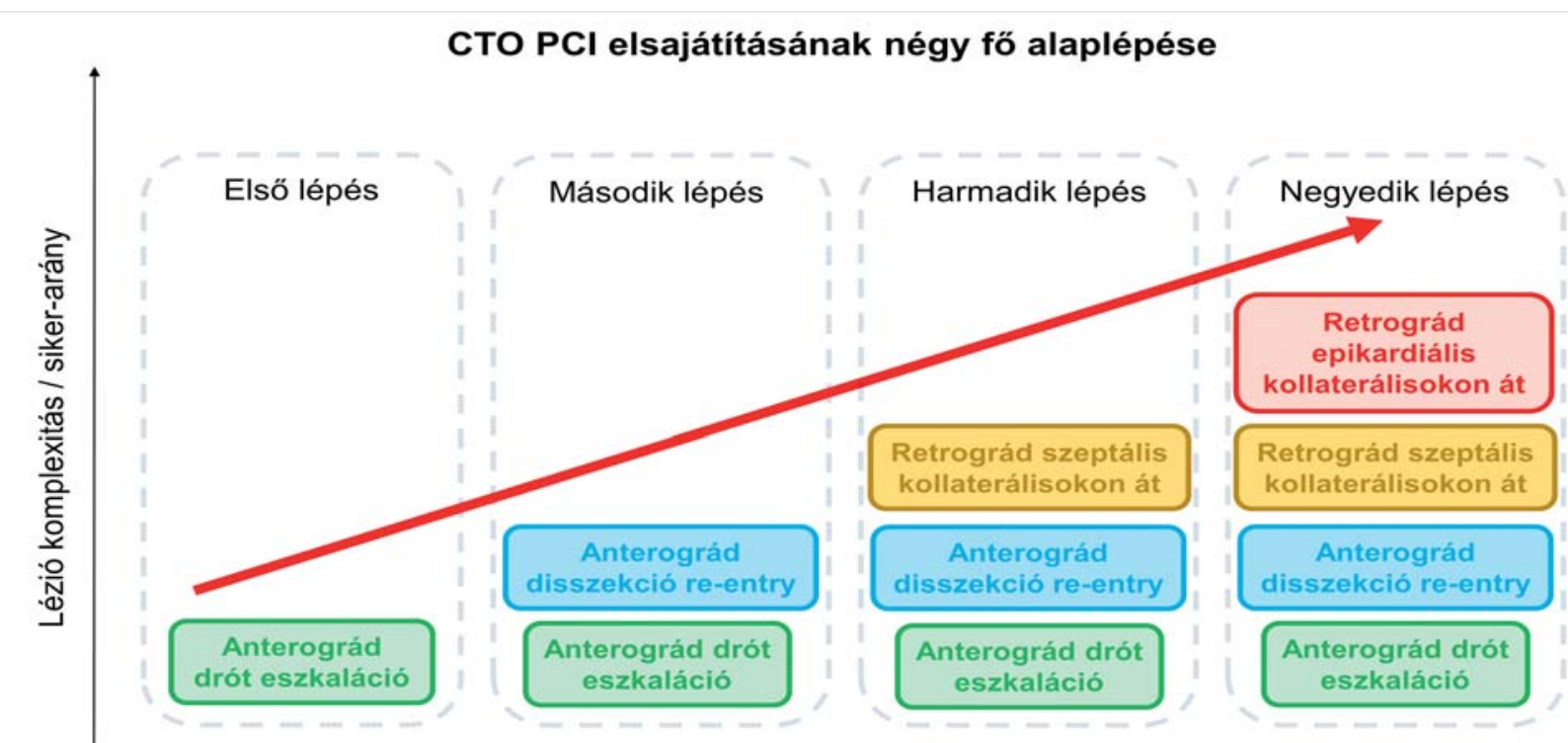

Esetszám

2. ÁBRA. A krónikus teljes koszorúér-elzáródás perkután intervenció elsajátításának négy alapvető lépése

- beavatkozás sikeres kimenetelének predikciója a rendelkezésre álló eszközök és intervenciós tapasztalati adottságok alapján (25), valamint

- az intervenció időigényének becslésére (több magas komplexitású eset egy napra történő tervezése jelentősen megterhelheti a centrum emberi erőforrásait) (26).

A CTO pontrendszerek rutinszerú alkalmazásának kritikus szerepe van az anterográd technikák sikerének becslésében továbbá a beavatkozások megtervezésében, valamint a beteg előzetes tájékoztatásában is.

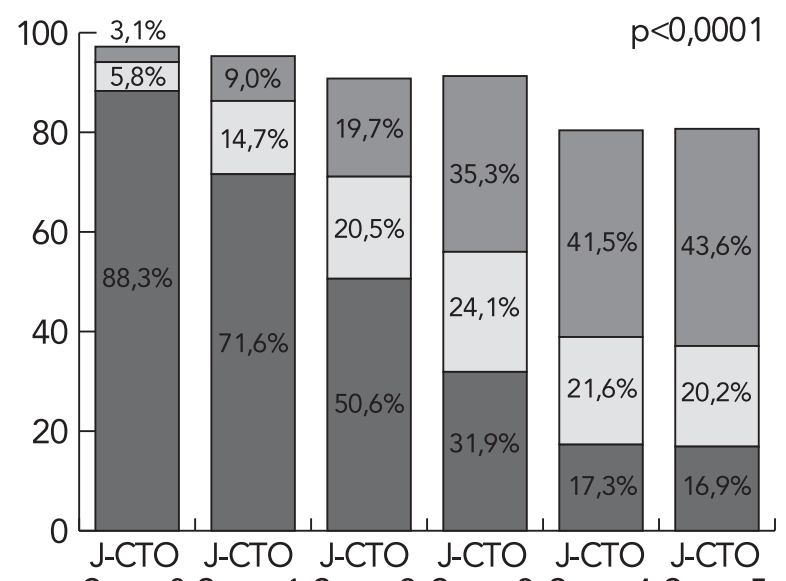

Score 0 Score 1 Score 2 Score 3 Score 4 Score 5
$\square$ AWE
$\square$ ADR
$\square$ Retrográd

3. ÁBRA. Sikeres revaszkularizációs technikák megoszlása a lézió komplexitásának függvényében a J-CTO score alapján (6)

\section{A technika megválasztása}

Az optimális elsődleges és az azt követő intervenciós stratégiák kiválasztása a koronária, illetve az okklúzió anatómiájának alapján kulcsfontosságú a beavatkozás sikeréhez (27). Igen lényeges az angiográfiás kép alapos tanulmányozása (szükség szerint akár 15-20 percig) az intervenciót megelőzően. A krónikus teljes okklúzió patomorfológiai (4. ábra) felépítése, azaz a proximális sapka alakja és mésztartalma, a mikrocsatornák jelenléte, valamint a distalis sapka morfológiája és a distalis érszakasz minősége alapvető az intervenció megtervezéséhez. Az okklúzió anatómiájának precíz és megfelelő vizualizációjához az esetek legnagyobb hányadában szimultán ipsilaterális és kontralaterális kontraszt-injekció („dual angiography”) szükséges, amelynek során nagyítás és a képmező mozgatása nélkül megfelelő hosszúságú felvételeket kell készítenünk. Alternatív lehetőség a mikrokatéterbe adott kontrasztanyag („tip injection”) a distalis érszakasz vizualizálására (5. ábra), főleg ha elsősorban ipsilaterális epikardiális kollaterálisok dominálnak -

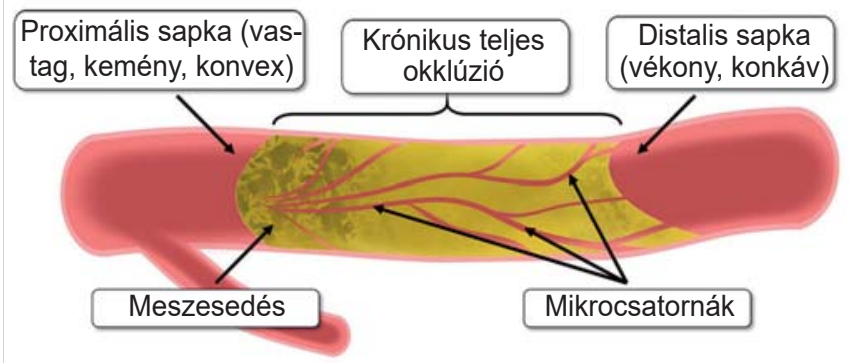

4. ÁBRA. A krónikus teljes koszorúér-elzáródások morfológiájának sematikus felépítése 


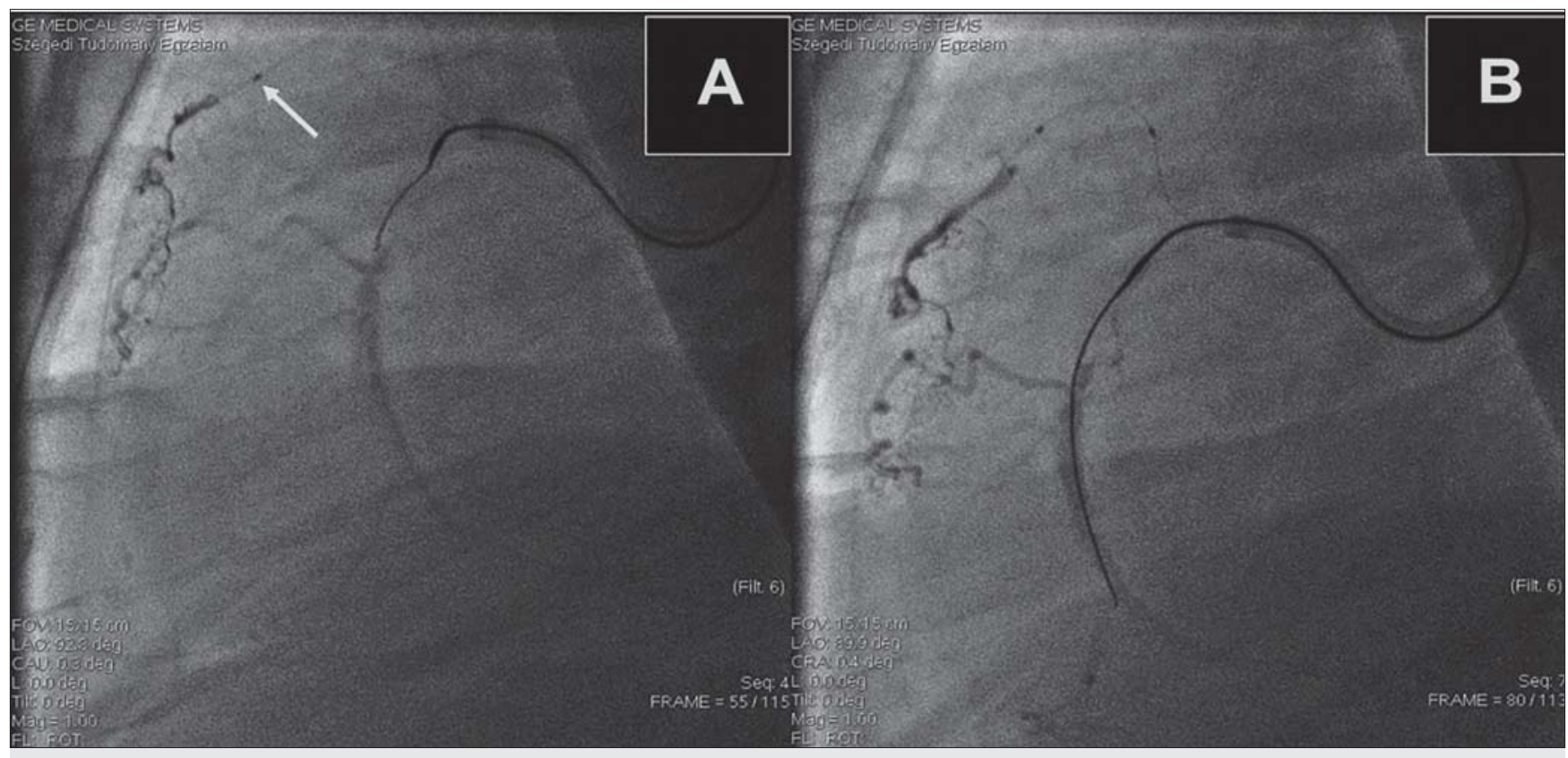

5. ÁBRA. Ipsilateralis szimultán kontraszt injekció vezérelte anterográd CTO-revaszkularizáció

ugyanakkor kontralaterális, kollaterális hálózat feltérképezése esetén a konvencionális kontralaterális injekció eredményesebb képet adhat.

Jelenleg két algoritmus érhető el a klinikai gyakorlatban, amely segítséget nyújt a CTO rekanalizációs stratégia megválasztásában:

- a hibrid algoritmus (27) és az

- Asia Pacific algoritmus (28).

A hibrid algoritmus (6. ábra) bilaterális injekció segítségével 4 anatómiai tulajdonságra fókuszálva (proximális sapka alakja, distalis érszakasz minősége, intervenciós kollaterálisok jelenléte, és a lézió hoszszúsága [> vagy <20 mm]) tesz javaslatot a kezdő stratégia megválasztására (anterográd/retrográd, vezetődrót-eszkaláció/disszekció re-entry) (29). A hibrid algoritmus lényege a szükség esetén gyors és rugalmas intervenciós - anterográd és retrográd - straté- giák alkalmazása (a kezdő technika csupán az esetek 50-60\%-ában eredményes), amely emeli revaszkularizációk sikerességet (6).

Az Asia Pacific algoritmus elsősorban az intra-plakk rekanalizációs szemléletmódot képviseli, azaz kevésbé támaszkodik a disszekció-re-entry technikákra. Ez a stratégia - szemben a hibrid algoritmussal - intravaszkuláris ultrahang (IVUS) vagy CT-angiográfia (CTA) gyakori alkalmazását igényli (28).

Bilaterális kontraszt injekció alkalmazása kritikus az okklúzió és a kollaterális hálózat anatómiájának megítélésében, amelyet szinte minden CTO $\mathrm{PCI}$ esetében rutinszerúen ajánlott elvégezni. Algoritmikus stratégiaválasztás és a rendelkezésre álló technikák alternáló használata növeli a CTO-intervenció sikeresélyét valamint segíti az ad hoc döntések elkerülését a beavatkozás alatt.

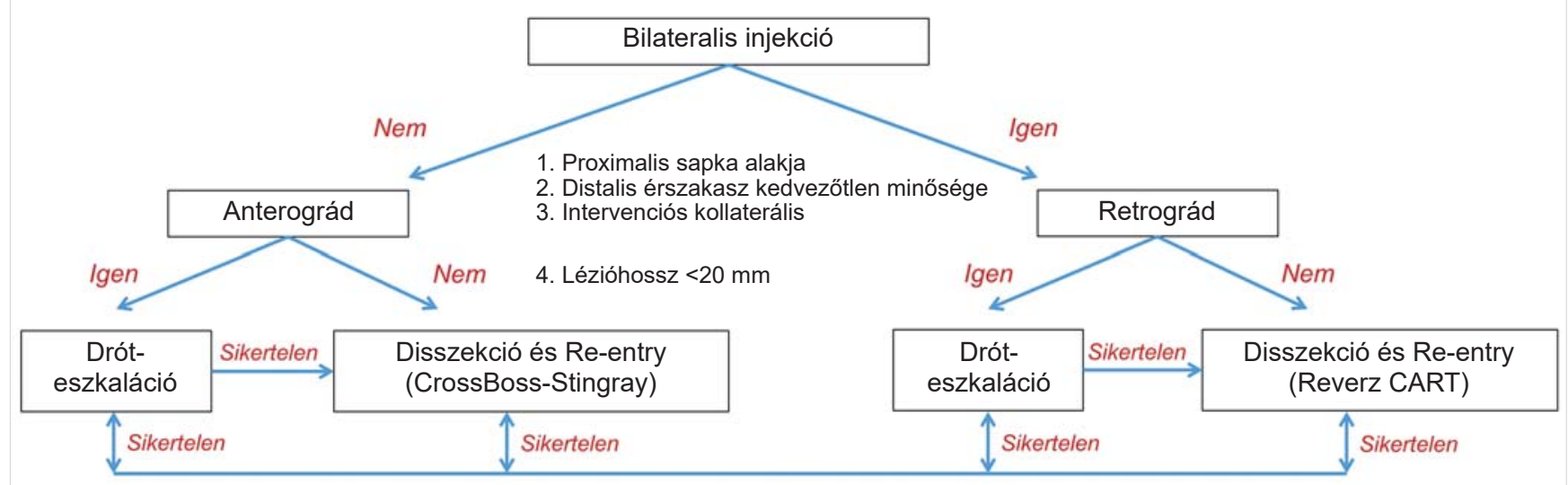

6. ÁBRA. A hibrid algoritmus (14) 


\section{Anterográd dróteszkalációs (antegrade wire escalation [AWE]) technikák}

Az anterográd dróteszkaláció a jelenkori CTO intervenciós gyakorlatban az alapvetö, és legelterjedtebben alkalmazott technika, amelynek hatékonysága föleg kevésbé komplex okklúziók esetén jelentős. Ismerete és biztonságos alkalmazása a különböző bonyolultabb technikák (ADR és retrográd) elsajátításának is alapját képezi (3. ábra). Az AWE-technika alkalmazása optimális a rövid $(<20 \mathrm{~mm})$, egyenes, és mikrocsatornákat tartalmazó elzáródások esetén (4. ábra).

\section{Eszközők és a behatolási kapu \\ megválasztása}

A megfelelö katéterszupport biztosítása rendkívül fontos a CTO-intervenciókban, hiszen ez jelentősen képes javítani a vezetődrótok penetrációs képességét. A megfelelő szupport biztosítására számos technika áll rendelkezésére:

- nagy átmérőjü vezetőkatéterek,

- mikrokatéterek,

- extenziós katéterek vagy

• a különböző horgonyzó technikák.

\section{Radiális vs. femoralis behatolás}

A koszorúér-intervenciók többségében ma általánosan elfogadott a radiális behatolás elsődleges alkalmazása. CTO PCl esetén nem ennyire egyértelmű a kérdés megválaszolása, hiszen általánosan elfogadott tény, hogy az elérhető és a beteg által tolerált legnagyobb belső átmérőjű, vezetőkatéter a preferálandó, amely számos esetben femorális behatolást tesz szükségessé. A 7-8 F (French) transfemoralis vezetőkatéterek használata a leggyakrabban javasolt (lehetöleg hosszú, $45 \mathrm{~cm}$-es sheath használatával), amely optimális szupportot biztosít, ugyanakkor e katéterekkel a vaszkuláris szövődmények esélye is magasabb (30). Ultrahang-vezérelte punkció (31) és/vagy fluoroszkópiás ellenőrzés mellett (32) csökkenthető a perifériás komplikációk kialakulásának esélye, ha az operatör a femoralis artéria használata mellett dönt. Ezzel szemben számos CTO-operatör kombinált radialis-femoralis vagy bilaterális radiális beavatkozást alkalmaz, amely a $7 \mathrm{~F}$ „slender sheath" (Terumo, Somerset, New Jersey) alkalmazásával elegendő belső diamétert és támasztékot biztosíthat. A „hibrid vaszkuláris” szemlélet elterjedése, azaz a kombinált radialis és femoralis behatolás jó megoldás az esetek többségében, mivel a nagy átmérőjü femoralis vezetőkatéter megfelelő anterográd szupportot ad, míg a radialisan feljuttatott katéter (kisebb átmérőjű sheath [6-7 F]) elegendő teret biztosít a retrográd eszközök felvezetéséhez (33).

\section{Mikrokatéterek}

Mikrokatéterek a CTO-intervencióban minden esetben alkalmazandóak, mint a legegyszerübb, de egyben leghatékonyabb megoldás a vezetődrót penetrációs ké- pességének javítására. A mikrokatéterek a vezetődrót végének formálását/újra formálását, és kicserélését is lehetővé teszik a pozíció elvesztése nélkül. Jelen gyakorlatban az over-the-wire (OTW) ballonkatéterek alkalmazása mikrokatéterek helyett nem ajánlott, mivel a sugárfogó marker a ballon közepén helyezkedik el, ezáltal megnehezíti a precíz pozicionálást, valamint az OTW-ballonok fizikai tulajdonságai sem alkalmasak az okklúzión történő áthatolásra.

\section{Extenziós katéterek}

Ezen eszközök használata (Guidezilla [Boston Scientific, Natick, MA, USA]; GuideLiner [Teleflex, Wayne, PA, USA]) - amelyet az angol nomenklatúra „motherand-child" technikaként tart számon (34) - növeli azt a koaxiális erőt, amelyet a drót kifejthet a kalcifikált szövetre. Az extenziós katéterek mindemellett elősegítik a különböző eszközök lejuttatását is distalis léziók vagy kanyarulatos proximális koronáriák esetén, így csökkentik a koszorúér-szájadékok disszekciójának a mély vezetőkatéter inkubációból származó veszélyét. Extrém távolságok, vagy tortuozitás esetén többszöri extenziós katéter használata is lehetséges - amely teleszkópos technikaként is ismert (angol nomenklatúrában „mother-daughter-granddaughter" technika) (35) - azonban ez mindenképp $8 \mathrm{~F}$ vezetőkatéter használatához kötött.

\section{Horgonyzó technikák}

Számos horgonyzó technika elérhető, amelyek célja ugyancsak a vezetőkatéter szupportjának növelése. A horgonyzás általános koncepciója, hogy egy második levezetett vezetődróton keresztül ballont fújunk fel, amely a vezetőkatétert az ér szájadékában "lehorgonyozza”. E technikának több formája létezik: az okklúziótól proximálisan elhelyezkedő oldalágban (oldalág horgony) (36); az okklúziótól proximálisan a föérben (koaxiális horgony (37) - a ballon rögzíti a mikrokatétert is az érfalhoz); az okklúziótól distalisan (distalis horgony (38) a vezető drót átjutását követően, amely elsősorban a stent lejuttatását segítheti); vagy a subintimalis térben (subintimalis horgony) (39). A horgonyzás alkalmazása esetén figyelembe kell vennünk az oldalágakban okozott érsérülés vagy az okklúzió miatti hosszan tartó iszkémia veszélyét.

Megfelelő támaszték biztosítása esszenciális a vezetődrót penetrációs képességének javítása érdekében, amelyhez a lehetö legnagyobb átméröjü katéterek használata javasolt. Mikrokatéterek minden CTO-intervenció esetében rutinszerüen alkalmazandóak. Egyéb technikák, mint például az extenziós katéterek vagy horgonyzási technikák további segítséget nyújthatnak a koaxiális erö növelése érdekében.

\section{A vezetődrót előkészítése és drótozási technikák}

Az anterográd drót eszkalációs technika 4 fő fázisból áll, amely az 
- okklúzió proximális sapkájához való eljutást,

- a proximális sapka penetrációját,

- a drót okklúzióban történő navigációját, és

- a distalis valódi lumenbe jutást jelenti.

\section{A CTO megközelítése}

A speciális CTO-vezetődrót és a mikrokatéter atraumatikus lejuttatása a proximális sapkához reguláris intervenciós drótok segítségével történik. Ezzel elkerülhetjük a proximális érszakasz sérülését, továbbá a dedikált CTO-drót görbületének útközbeni torzulását. $A$ proximális sapkát elérve a mikrokatéter e drótra rávezethető, és ott az eredeti drót a speciális CTO-vezetődrótra kicserélhető. Eközben mikrokatéter tip-injekció egyes esetekben további információt nyújthat a proximális sapka anatómiájáról.

\section{A proximális sapka penetrációja}

A vezetődrót megválasztását elsősorban a proximális sapka anatómiája határozza meg. Abban az esetben, ha az ér lefutása jól követhető (rövid, egyenes érszakasz), merev kúpos végü drótok a választandóak (Gaia $2^{\text {nd }}$, vagy igen kemény sapka esetén Confianza Pro 12 [Asahi Intecc. Nagoya, Japán]), ugyanakkor, ha az ér architektúrája nem egyértelmü, kevésbé merev, polimer bevonatú (Fielder XT család [Asahi Intecc. Nagoya, Japán], vagy Pilot 200 [Abbott Laboratories, Chicago, US]) vagy polimer bevonat nélküli drótok (Ultimate Bros 3, Miracle [Asahi Intecc. Nagoya, Japán]) képesek az ér lefutását megfelelően követni. Az ideális vezetődrót görbület a proximális sapka penetrációjához az $1 \mathrm{~mm}$ hosszú $30-45^{\circ}$ szöget bezáró, amely maximális penetrációs kapacitás mellett a mikrocsatornák útvonalát is megfelelően követni tudja csökkentve a subintimalis térbe jutás esélyét. A proximális sapka extrém kalcifikációja esetén a drót rotáció nélküli szúró jellegű előre mozgatása (penetrációs technika) is eredményes lehet.

\section{A vezetődrót navigációja az okklúzióban}

A proximális sapka sikeres áttörését követően az okkludált szegmenten belül történő manipuláció eltérő technikát igényel, amely gyakori drótcserével is járhat (eszkaláció/deeszkaláció). A „sliding” technika, amely mérsékelt rotációs mozgás és penetrációval kombinált drótozást jelent, polimer bevonatú drótokkal eredményes lehet, ugyanakkor rezisztens léziók esetén erőteljesebb rotációs mozgás „drilling technika” válhat szükségessé. A „drilling-technikához” a Gaia-vezetődrót család az ideális választás (Gaia $1^{\text {st }}, 2^{\text {nd }}, 3^{\text {rd }}$ ) mivel ezen drótok mikrostruktúrája megfelelő manőverezési képességet biztosít még a hosszú és tortuózus érszakaszok esetén is minimalizálva a perforáció esélyét.

\section{Behatolás a valódi lumenbe}

Miután a vezetődrót elérte a distalis sapka síkját, mérsékelten (Gaia család, Ultimate Bros 3, Miracle 6) vagy kifejezetten merev (Confianza Pro 12) végű drót használata eredményezheti a valódi lumenbe jutást, ugyanakkor a distalis drót pozíciónak a megerősítése nagyon lényeges, hiszen esetleges perforáció dróttal többnyire nem veszélyes, ugyanakkor mikrokatéterrel vagy ballonnal perikardiális tamponádot okozhat. A drót valódi lumen pozíciójának megerősítése többnyire kontralaterális angiogáfiával történik. Ha a bejuttatott mikrokatéterből vért tudunk aspirálni, vagy nyomásgörbe detektálható a mikrokatéteren keresztül, az szintén kisegítő információt nyújthat az intraluminalis pozícióról.

\section{"Trapping" technika}

Az esetek jelentős többségében több, különböző penetrációs készségű vezetődrótra is szükség lehet. Ilyen esetekben szükséges lehet a mikrokatéter eltávolítása az első drót helyben hagyásával. A „trapping” technika során egy segédballont fújunk fel a vezetőkatéteren belül $(2,0 \mathrm{~mm}$ átmérőjű $6 \mathrm{~F}$-hez, 2,5 $\mathrm{mm}$ átmérőjű 7 F-hez). Ez hozzápréseli a vezetődrótot a katéter falához stabilizálva annak pozícióját a mikrokatéter eltávolításához. Erre a célra fejlesztett speciális ballonok előnye (Trapper, Boston Scientific, Natick, MA, USA), hogy igen alacsony profiljuk kevés helyet foglal el, továbbá megegyező hosszúságúak a vezetőkatéterével, így fluoroszkópia nélkül is biztonságosan behelyezhetők a koronária sérülésének elkerülésével.

\section{Vezetődrótok tudatos megválasztása, előkészítése, és a drótozási manőverek megfelelő alkalmazása alapvető fontosságú a sikeres CTO PCI érdekében. $A$ drótpozíció megtartása kritikus a dróteszkaláció és deeszkaláció során, ezért a trapping technika elsajá- títása és megfelelő alkalmazása fontos részét képezi az anterográd CTO-operatörök gyakorlatának.}

\section{Speciális anterográd drótozási technikák} Ideális esetben az anterográd eszkalációs technika sikeres (7. ábra, A panel), mindazonáltal az esetek jelentékeny hányadában a drót a subintimalis térbe jut, ahonnan igen nehéz és sokszor csak nagy gyakorlattal lehetséges a visszavezetésük a lumen felé. $E$ célból a drót végét újra kell formáznunk, ekkor 70-90-os 2-3 mm hosszú görbületet képezünk. Ki kell emelnünk ugyanakkor, hogy subintimalis pozíció esetén a legjobb eredményt a dedikált anterográd disszekció re-entry technika alkalmazása adja erre specializált eszközökkel (CrossBoss mikrokatéter, Stingray ballon [mindkettő Boston Scientific, Natick, MA, USA]) (40). A csupán dróttal történő ún. random re-entry technika azzal a veszéllyel jár, hogy nagy subintimalis haematomát képezünk, ezután már egyre nehezebb a valódi lumenbe jutás. A hosszú szakaszon subintimalis stentelés pedig magas restenosis és reokklúziós rátát okozhat $(41$, 42). A dedikált re-entry eszközökön kívül is lehetséges azonban a distalis valódi lumenbe visszajutás a következő eljárások alkalmazásával. 
A

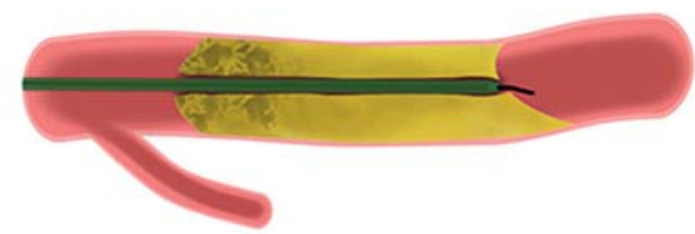

B

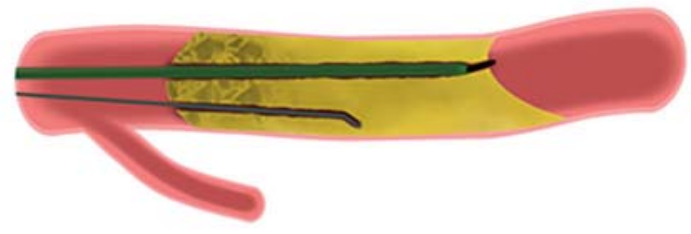

C

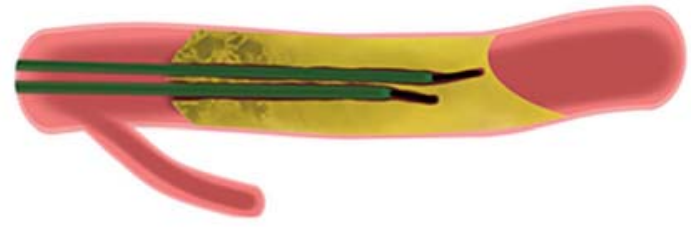

D

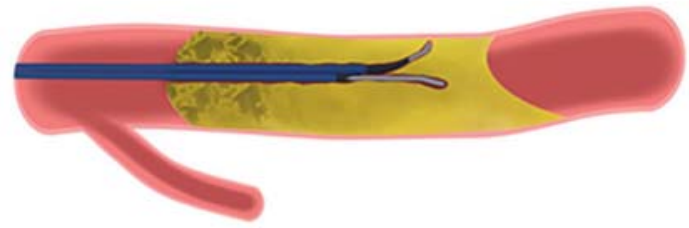

E

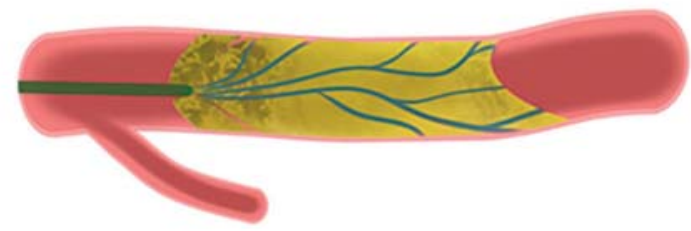

7. ÁBRA. Speciális anterográd drótozási technikák: eszkalációs technika (A); paralleldrótozás (B); „libikóka technika” (C); kettős lumenú mikrokatéter technika (D); mikrocsatorna ('Carlino') technika (E)

\section{Paralleldrótozási technika (43)}

Abban az esetben, ha az első vezetődrót helyzete subintimalisnak sejthető, annak helyben hagyása (mikrokatéter nélkül) mellett egy második vezetődrót szimultán felvezetése - parallel helyzetben az elsőhöz képest ( 7 . ábra, $B$ panel) - elősegítheti második vezetődrót intraluminalis vezetését azáltal, hogy a helyben hagyott első drót kiegyenesíti az adott érszakaszt, valamint meggátolja hogy a második drót ugyanazt a fals utat kövesse. Kettőnél több vezetődrót is használható, ugyanakkor ez jelentősen megnehezítheti az angiográfiás tájékozódást.

\section{"Libikóka technika" (43)}

A libikóka technika egy módosított paralleldrótozási eljárás, amely során az első vezetődrót és mikrokatéter a subintimalis térben marad, mellé pedig egy második mikrokatéter-vezetődrót együttest vezetünk az okklúzióba. Ezen két mikrokatéter segítségével felváltva manipulálhatunk a két dróttal (7. ábra C panel). llyen esetben második drótként érdemes merev, de könnyen irányítható eszközöket választani, mint a Gaia-vezetődrótok, vagy a Miracle 6, illetve 12.

\section{Kettős lumenü mikrokatéterek (44)}

A kettős lumenű mikrokatéterek alkalmazása kezdeti subintimalis drótpozíció felvétele során ideális opcióként szolgálnak a második vezetődrót helyes irányba juttatásához (7. ábra D-panel). Ezen mikrokatéterek monorail- (distalis) és over-the-wire (proximális) portot tartalmaznak. Ha a primer vezetődrót subintimalis pozícióba jut, a mikrokatétert trapping technikával kettős lumenü katéterre cserélhetjük, majd az oldalsó proximális porton keresztül (over-the-wire) a szekunder vezetődrót intraluminalis drót manipulációra használható. A kettős lumenű mikrokatéterek használata ugyancsak jelentős szerepet játszik a bifurkációs okklúziók oldalágának rekanalizációjában.

\section{"Szezám tárulj technika" (45)}

Ezen metódus csak olyan CTO-anatómia esetében alkalmazható, ahol az okklúzió közvetlenül distalisan kezdődik az oldalágtól. A „szezám tárulj technika” lényege, hogy az oldalágba jutott vezetődróton ballonnal tágítást végzünk, amely módosítja az okklúzió architektúráját elősegítvén a második vezetődrót könnyebb bevezetését a distalis valódi lumen felé. Mindazonáltal ez a technika csak egy speciális koronária-anatómia esetén alkalmazható, valamint a subintimalis drótozás esélye is magasabb („,side-BASE technika”) (46), amely így jelentős mértékben korlátozza ennek a technikának széles körủ alkalmazhatóságát.

\section{Mikrocsatorna-technika („Carlino technika”) (47)}

A mikrocsatorna-technika lényege a mikrokatéter okklúzióba vezetése, majd finoman 0,5-1,0 ml kontrasztanyag injektálása az okklúzió testébe, amely kontrollált hidraulikus disszekciót okoz a mikrocsatornák mentén elősegítve az okklúzió „felpuhítását”, valamint a koronária lefutásának feltérképezését (7. ábra, $E$ panel). A Carlino-technika eredendően anterográd drót eszkaláció elősegítésére lett fejlesztve, azonban ez gyakran a subintimalis tér megnyitásával is járhat, amely a dedikált disszekciós re-entry technikák alkalmazását követeli meg (Stingray-ballon), így ez a technika csak megfelelő intervenciós gyakorlattal alkalmazható biztonságosan.

Komplex anterográd technikák alkalmazásának elsajátítása jelentós tapasztalatot és megfelelő eszköztárat igényel a biztonságos használathoz, azonban e módszerek hasznos stratégiaként szolgálnak, ha a vezetődrót subintimalis pozícióba jutott. Subintimalis drótozás, és dedikált re-entry eszközök nélküli anterográd disszekció és re-entry technika (klasszikus STAR-technika) klinikai alkalmazását nem javasoljuk a mai intervenciós gyakorlatban a magas restenosis és reokklúziós ráta miatt. 


\section{A rekanalizáció befejező lépései}

Amint a vezetődrót a distalis valódi lumenbe jutott, és annak intraluminalis pozíciójáról meggyőződtünk, a mikrokatéteren át a drót cseréje következik hagyományos vezetődrótra, célszerủen extra szupport drótra (Sion Blue ES, BHW, Grand Slam). Ennek a lépésnek jelentősége, hogy a CTO-vezetődrótok distalis vége jó penetrációs képességü, így könnyen okozhatnak distalis perforációt. E ponttól az intervenció az angioplasztika általánosan ismert lépéseinek megfelelően zajlik (ballon predilatáció és stentimplantáció), ugyanakkor az esetek kis százalékában a ballon felvezetése („balloon unrossable" léziók [az esetek 6-8\%-ában, sikeres distalis drótozást követően]) $(48,49)$ és a léziónak megfelelő expanziója („,balloon undilatable” léziók [esetek $12 \%$-a sikeres distalis drótozást követően]) (50) sikertelen, amely megakadályozhatja a rekanalizált érszakasz stentelését. A ballonnal átjárhatatlan vagy tágíthatatlan léziók megoldása gyakran speciális technikákat igényelnek - mint például „grenadoplasztika” (azaz kicsiny ballon szándékosan előidézett ruptúrája a proximális sapka szintjében), lézerkatéter, rotációs arterectomia, vagy különböző „cutting” ballonok (spirális vagy paralel vágópengékkel felszerelt ballonok). Ezen eszközök, eljárások helyes algoritmus szerinti alkalmazása az esetek nagy részében lehetővé teszi az intervenciók biztonságos és hatékony befejezését (29).

A speciális CTO-vezetődrótok cseréje fontos lépés a ballon és a stent levezetését megelőzően, ezzel minimálisra csökkentjük a vezetődrót-okozta traumatikus distalis érsérülés lehetőségét. $A z$ angioplasztika az esetek nagy többségében ezután konvencionális módon kivitelezhető, azonban anterográd rekanalizációk esetében a nagyobb és körkörös plakktömeg miatt egyéb plakk-modifikációs technikák használata is szükséges lehet a ballon vagy stentek kihelyezéséhez és megfelelő expanziójához.

\section{Következtetések}

Anterográd CTO-rekanalizációs technikák széles körben és hatékonyan alkalmazhatóak a mai CTO-intervenciós gyakorlatban, így ezen szemlélet és gyakorlat megszerzése és alkalmazása a CTO-tréning egyik legfontosabb lépése, továbbá alapul szolgál a komplex retrográd és anterográd disszekciós re-entry technikák elsajátításához is.

\section{Irodalom}

1. Fefer $P$, Knudtson ML, Cheema AN, et al. Current perspectives on coronary chronic total occlusions: the Canadian Multicenter Chronic Total Occlusions Registry. J Am Coll Cardiol 2012; 59: 991-7. doi: 10.1016/j.jacc.2011.12.007

2. Jeroudi OM, Alomar ME, Michael TT, et al. Prevalence and ma- nagement of coronary chronic total occlusions in a tertiary Veterans Affairs hospital. Catheter Cardiovasc Interv 2014; 84: 637-43. doi: 10.1002/ccd. 25264

3. Christofferson RD, Lehmann KG, Martin GV, Every N, Caldwell $\mathrm{JH}$, Kapadia SR. Effect of chronic total coronary occlusion on treatment strategy. Am J Cardiol 2005; 95: 1088-91. doi: 10.1016/j.amjcard.2004.12.065

4. Ramunddal T, Hoebers LP, Henriques JP, et al. Chronic total occlusions in Sweden - a report from the Swedish Coronary Angiography and Angioplasty Registry (SCAAR). PLoS One 2014; 9: e103850. doi. 10.1371/journal.pone.0103850

5. Azzalini L, Jolicoeur EM, Pighi M, et al. Epidemiology, Management Strategies, and Outcomes of Patients With Chronic Total Coronary Occlusion. Am J Cardiol 2016; 118: 1128-1135. doi: 10.1016/j. amjcard.2016.07.023

6. Tajti P, Karmpaliotis D, Alaswad K, et al. The Hybrid Approach to Chronic Total Occlusion Percutaneous Coronary Intervention: Update From the PROGRESS CTO Registry. JACC Cardiovasc Interv 2018. doi: 10.1016/j.jcin.2018.02.036

7. Wilson WM, Walsh SJ, Yan AT, et al. Hybrid approach improves success of chronic total occlusion angioplasty. Heart 2016; 102 : 1486-93. doi: 10.1136/heartjnl-2015-308891

8. Maeremans J, Walsh S, Knaapen P, et al. The Hybrid Algorithm for Treating Chronic Total Occlusions in Europe: The RECHARGE Registry. J Am Coll Cardiol 2016; 68: 1958-1970. doi: 10.1016/j. jacc.2016.08.034

9. Habara M, Tsuchikane E, Muramatsu T, et al. Comparison of percutaneous coronary intervention for chronic total occlusion outcome according to operator experience from the Japanese retrograde summit registry. Catheter Cardiovasc Interv 2016; 87: 1027-35. doi: $10.1002 /$ ccd. 26354

10. Werner G. A Randomized Multicentre Trial to Evaluate the Utilization of Revascularization or Optimal Medical Therapy for the Treatment of Chronic Total Coronary Occlusions (EuroCTO). EuroPCR 2017. Paris, 2017. doi: 10.1093/eurheartj/ehy220

11. Sapontis J, Salisbury AC, Yeh RW, et al. Early Procedural and Health Status Outcomes After Chronic Total Occlusion Angioplasty: A Report From the OPEN-CTO Registry (Outcomes, Patient Health Status, and Efficiency in Chronic Total Occlusion Hybrid Procedures). JACC Cardiovasc Interv 2017; 10: 1523-1534. doi: 10.1016/j. jcin.2017.05.065

12. Hannan EL, Zhong $Y$, Jacobs AK, et al. Patients With Chronic Total Occlusions Undergoing Percutaneous Coronary Interventions: Characteristics, Success, and Outcomes. Circ Cardiovasc Interv 2016; 9: e003586. doi: 10.1161/CIRCINTERVENTIONS.116.003586 13. Brilakis ES, Banerjee S, Karmpaliotis D, et al. Procedural Outcomes of Chronic Total Occlusion Percutaneous Coronary Intervention: A Report From the NCDR (National Cardiovascular Data Registry). JACC Cardiovasc Interv 2015; 8: 245-53. doi: 10.1016/j. jcin.2014.08.014

14. Tajti $P$, Burke MN, Karmpaliotis $D$, et al. Update in the Percutaneous Management of Coronary Chronic Total Occlusions. JACC Cardiovasc Interv 2018; 11: 615-625. doi: 10.1016/j.jcin.2017.10.052 15. Morino $Y$, Abe M, Morimoto $T$, et al. Predicting successful guidewire crossing through chronic total occlusion of native coronary lesions within 30 minutes: the J-CTO (Multicenter CTO Registry in Japan) score as a difficulty grading and time assessment tool. JACC Cardiovasc Interv 2011; 4: 213-21. doi: 10.1016/j.jcin.2010.09.024 16. Alessandrino G, Chevalier B, Lefevre T, et al. A Clinical and Angiographic Scoring System to Predict the Probability of Successful First-Attempt Percutaneous Coronary Intervention in Patients With Total Chronic Coronary Occlusion. JACC Cardiovasc Interv 2015; 8: 1540-8. doi: 10.1016/j.jcin.2015.07.009

17. Christopoulos G, Kandzari DE, Yeh RW, et al. Development and Validation of a Novel Scoring System for Predicting Technical Success of Chronic Total Occlusion Percutaneous Coronary Interventions: The PROGRESS CTO (Prospective Global Registry for the Study of Chronic Total Occlusion Intervention) Score. JACC Cardiovasc Interv 2016; 9: 1-9. doi: 10.1016/j.jcin.2015.09.022 
18. Galassi AR, Boukhris M, Azzarelli S, Castaing M, Marza F, Tomasello SD. Percutaneous Coronary Revascularization for Chronic Total Occlusions: A Novel Predictive Score of Technical Failure Using Advanced Technologies. JACC Cardiovasc Interv 2016. doi: 10.1016/j.jcin.2016.01.036

19. Maeremans J, Spratt JC, Knaapen P, et al. Towards a contemporary, comprehensive scoring system for determining technical outcomes of hybrid percutaneous chronic total occlusion treatment: The RECHARGE score. Catheter Cardiovasc Interv 2017. doi: 10.1002/ ccd. 27092

20. Ellis SG, Burke MN, Murad MB, et al. Predictors of Successful Hybrid-Approach Chronic Total Coronary Artery Occlusion Stenting An Improved Model With Novel Correlates. JACC Cardiovasc Interv 2017; 10: 1089-1098. doi: 10.1016/j.jcin.2017.03.016

21. Danek BA, Karatasakis A, Karmpaliotis D, et al. Development and Validation of a Scoring System for Predicting Periprocedural Complications During Percutaneous Coronary Interventions of Chronic Total Occlusions: The Prospective Global Registry for the Study of Chronic Total Occlusion Intervention (PROGRESS CTO) Complications Score. J Am Heart Assoc 2016; 5. doi: 10.1161/ JAHA.116.004272

22. Tanaka $\mathrm{H}$, Morino $\mathrm{Y}$, Abe $\mathrm{M}$, et al. Impact of J-CTO score on procedural outcome and target lesion revascularisation after percutaneous coronary intervention for chronic total occlusion: a substudy of the J-CTO Registry (Multicentre CTO Registry in Japan). Eurolntervention 2016; 11: 981-8. doi: 10.4244/EIJV11I9A202

23. Christopoulos G, Wyman RM, Alaswad K, et al. Clinical Utility of the Japan-Chronic Total Occlusion Score in Coronary Chronic Total Occlusion Interventions: Results from a Multicenter Registry. Circ Cardiovasc Interv 2015; 8: e002171. doi: 10.1161/CIRCINTERVENTIONS.114.002171

24. Nombela-Franco L, Urena $M$, Jerez-Valero $M$, et al. Validation of the J-chronic total occlusion score for chronic total occlusion percutaneous coronary intervention in an independent contemporary cohort. Circ Cardiovasc Interv 2013; 6: 635-43. doi: 10.1161/CIRCINTERVENTIONS.113.000447

25. Azzalini L, Brilakis ES. Ipsilateral vs. contralateral vs. no collateral (antegrade only) chronic total occlusion percutaneous coronary interventions: What is the right choice for your practice? Catheter Cardiovasc Interv 2017; 89: 656-657. doi: 10.1002/ccd.27005

26. Karatasakis A, Danek BA, Karmpaliotis D, et al. Comparison of various scores for predicting success of chronic total occlusion percutaneous coronary intervention. Int J Cardiol 2016; 224: 50-56. doi: 10.1016/j.ijcard.2016.08.317

27. Brilakis ES, Grantham JA, Rinfret S, et al. A percutaneous treatment algorithm for crossing coronary chronic total occlusions. JACC Cardiovasc Interv 2012; 5: 367-79. doi: 10.1016/j.jcin.2012.02.006

28. Harding SA, Wu EB, Lo S, et al. A New Algorithm for Crossing Chronic Total Occlusions From the Asia Pacific Chronic Total Occlusion Club. JACC Cardiovasc Interv 2017; 10: 2135-2143. doi: 10.1016/j.jcin.2017.06.071

29. Brilakis E. Manual of Coronary Chronic Total Occlusion Interventions: A Step-by-Step Approach. $2^{\text {nd }}$ ed. 2017.

30. Kinnaird T, Anderson R, Ossei-Gerning N, et al. Vascular Access Site and Outcomes Among 26,807 Chronic Total Coronary Occlusion Angioplasty Cases From the British Cardiovascular Interventions Society National Database. JACC Cardiovasc Interv 2017; 10: 635-644. doi: 10.1016/j.jcin.2016.11.055

31. Marquis-Gravel G, Tremblay-Gravel M, Levesque J, et al. Ultrasound guidance versus anatomical landmark approach for femoral artery access in coronary angiography: A randomized controlled trial and a meta-analysis. J Interv Cardiol 2018; 31: 496-503. doi: 10.1111/joic.12492

32. Fairley SL, Lucking AJ, McEntegart M, et al. Routine Use of Fluoroscopic-Guided Femoral Arterial Puncture to Minimise Vascular Complication Rates in CTO Intervention: Multi-centre UK Experience. Heart Lung Circ 2016; 25: 1203-1209. doi: 10.1016/j. hlc. 2016.04.006
33. Rinfret S, Joyal D, Nguyen CM, et al. Retrograde recanalization of chronic total occlusions from the transradial approach; early $\mathrm{Ca}$ nadian experience. Catheter Cardiovasc Interv 2011; 78: 366-74. doi. $10.1002 /$ ccd. 23140

34. Takahashi S, Saito S, Tanaka S, et al. New method to increase a backup support of a 6 French guiding coronary catheter. Catheter Cardiovasc Interv 2004; 63: 452-6. doi: 10.1002/ccd.20223

35. Finn MT, Green P, Nicholson W, et al. Mother-Daughter-Granddaughter Double GuideLiner Technique for Delivering Stents Past Multiple Extreme Angulations. Circ Cardiovasc Interv 2016; 9. doi: 10.1161/CIRCINTERVENTIONS.116.003961

36. Fujita $\mathrm{S}$, Tamai $\mathrm{H}$, Kyo $\mathrm{E}$, et al. New technique for superior guiding catheter support during advancement of a balloon in coronary angioplasty: the anchor technique. Catheter Cardiovasc Interv 2003; 59: 482-8. doi: 10.1002/ccd.10551

37. Fang HY, Wu CC, Wu CJ. Successful transradial antegrade coronary intervention of a rare right coronary artery high anterior downward takeoff anomalous chronic total occlusion by double-anchoring technique and retrograde guidance. Int Heart J 2009; 50: 531-8. doi: 10.1536/ihj.50.531

38. Mahmood A, Banerjee S, Brilakis ES. Applications of the distal anchoring technique in coronary and peripheral interventions. J Invasive Cardiol 2011; 23: 291-4.

39. Michael TT, Banerjee S, Brilakis ES. Subintimal distal anchor technique for „balloon-uncrossable” chronic total occlusions. J Invasive Cardiol 2013; 25: 552-4.

40. Danek BA, Karatasakis A, Karmpaliotis D, et al. Use of antegrade dissection re-entry in coronary chronic total occlusion percutaneous coronary intervention in a contemporary multicenter registry. Int $\mathrm{J}$ Cardiol 2016; 214: 428-437. doi: 10.1016/j.ijcard.2016.03.215

41. Valenti R, Vergara R, Migliorini A, et al. Predictors of reocclusion after successful drug-eluting stent-supported percutaneous coronary intervention of chronic total occlusion. J Am Coll Cardiol 2013; 61: 545-50. doi: 10.1016/j.jacc.2012.10.036

42. Azzalini L, Dautov R, Brilakis ES, et al. Procedural and Ionger-term outcomes of wire- versus device-based antegrade dissection and re-entry techniques for the percutaneous revascularization of coronary chronic total occlusions. Int J Cardiol 2017; 231: 78-83. doi: 10.1016/j.jicard.2016.11.273

43. Rathore S, Matsuo H, Terashima M, et al. Procedural and in-hospital outcomes after percutaneous coronary intervention for chronic total occlusions of coronary arteries 2002 to 2008: impact of novel guidewire techniques. JACC Cardiovasc Interv 2009; 2: 489-97. doi: 10.1016/j.jcin.2009.04.008

44. Chiu CA. Recanalization of difficult bifurcation lesions using adjunctive double-lumen microcatheter support: two case reports. J Invasive Cardiol 2010; 22: E99-103.

45. Saito S. Open Sesame Technique for chronic total occlusion. Catheter Cardiovasc Interv 2010; 75: 690-4. doi: 10.1002/ccd.22316 46. Roy J, Hill J, Spratt JC. The "side-BASE technique": Combined side branch anchor balloon and balloon assisted sub-intimal entry to resolve ambiguous proximal cap chronic total occlusions. Catheter Cardiovasc Interv 2017. doi: 10.1002/ccd.27422

47. Carlino M, Latib A, Godino C, Cosgrave J, Colombo A. CTO recanalization by intraocclusion injection of contrast: the microchannel technique. Catheter Cardiovasc Interv 2008; 71: 20-6. doi: 10.1002/ccd.21396

48. Patel SM, Pokala NR, Menon RV, et al. Prevalence and treatment of "balloon-uncrossable" coronary chronic total occlusions. J Invasive Cardiol 2015; 27: 78-84

49. Karacsonyi J, Karmpaliotis D, Alaswad K, et al. Prevalence, indications and management of balloon uncrossable chronic total occlusions: Insights from a contemporary multicenter US registry. Catheter Cardiovasc Interv 2016. doi: $10.1002 /$ ccd. 26780

50. Tajti $P$, Karmpaliotis D, Alaswad K, et al. Prevalence, Presentation and Treatment of "Balloon Undilatable" Chronic Total Occlusions: Insights from a Multicenter US Registry. Catheter Cardiovasc Interv 2018; 91: 657-666. doi: 10.1002/ccd.27510 



\title{
Kettős lumenứ mikrokatéterek alkalmazása krónikus teljes koronária-okklúzió katéteres revaszkularizációjában - Egy komplex beavatkozás tanulságai
}

\author{
Tajti Péter', Rami Abu Fanne², Ungi Imre', Katona András', Sasi Viktor', \\ Nagy Ferenc Tamás ${ }^{1}$
}

${ }^{1}$ Szegedi Tudományegyetem, Invazív Kardiológiai Részleg, II. sz. Belgyógyászati Klinika és Kardiológiai Központ, Szeged

${ }^{2}$ Hillel Yaffe Medical Center, Hadera, Izrael

Levelezési cím:

Dr. Tajti Péter

Szegedi Tudományegyetem, Invazív Kardiológiai Részleg, II. sz. Belgyógyászati Klinika és Kardiológiai Központ 6725 Szeged, Semmelweis u. 8.

E-mail: ptajti@gmail.com

A krónikus, teljes koszorúér-okklúzió (CTO) perkután intervenció (PCI) sikeres és biztonságos kivitelezhetősége jelentősen javult az arra felkészült centrumokban az elmúlt években. Ugyanakkor az anamnézisben szereplő aorto-koronáriás bypass graft $(A C B G)$ műtét jelentős mértékben csökkenti a $C T O P C l$ sikerességét miközben emeli a beavatkozáshoz társuló szövődmények gyakoriságát. A komplex koronária anatómiájából adódó nehézségek megoldása gyakran előrehaladott technikák ismeretét és eszközök alkalmazását követeli meg az effektív és biztonságos intervenciók kivitelezéséhez ezen speciális betegpopulációban. Jelen esetbemutatásunkban egy korábban két alkalommal sikertelen anterográd CTO-rekanalizáción átesett poszt-ACBG-beteg komplex retrográd intervencióját ismertetjük. A beavatkozás során a komplex jobb koronária-bifurkáció és a korábban erre varrott, majd elzáródott saphena véna graft helyzete miatt egyedülálló módon retrográd és anterográd kettős lumenű mikrokatéterrel facilitált rekanalizációs technikát alkalmaztunk, amely eredményeképpen sikeres CTO-megnyitást végeztünk.

Kulcsszavak: kettős lumenű mikrokatéter, aorto-koronáriás bypass graft műtét, krónikus teljes okklúzió, perkután koronária-intervenció

Application of dual lumen microcatheters in chronic total occlusion percutaneous coronary interventions lessons learned from a complex case

The success rate and safety of percutaneous coronary intervention (PCI) of chronic total coronary occlusions (CTO) in dedicated CTO centers has significantly improved recently. History of prior coronary artery bypass graft surgery $(\mathrm{CABG})$ in patients undergoing CTO $\mathrm{PCl}$ is associated with lower procedural success and higher rates of major procedural complications. Increased complexity of coronary anatomy requires the use of advanced interventional techniques and devices in order to achieve successful CTO revascularization safely and effectively in such a challenging patient population. In our current case we present a complex right coronary CTO recanalization in a patient with a history of CABG surgery who had undergone two previous failed antegrade CTO attempts in an outside hospital. Given the complexity of the distal right coronary artery bifurcation and pre-branch saphenous vein graft (SVG) anastomosis we used the dual lumen microcatheter in a unique way both retrogradely and antegradely to preserve side-branches and achieve success.

Keywords: dual lumen microcatheter, coronary artery bypass graft operation, chronic total occlusion, percutaneous coronary intervention 


\section{Bevezetés}

Korszerủ eszközök, újabb technikák és algoritmusok megjelenése a krónikus teljes koronária-okklúziók (CTO) perkután koronária-intervenciójában $(\mathrm{PCl})$ a sikerráta jelentős növekedését eredményezte (85$90 \%$ ) tapasztalt operatörök kezében (1-3). Ugyanakkor a korábban aorto-koronáriás bypass graft (ACBG) mütéten áteset betegek esetében továbbra is nagy technikai kihívást jelent a krónikus okklúziók revaszkularizációja. Ennek hátterében elsősorban többszörös társbetegségek jelenléte, illetve anatómiai sajátságok állnak (anasztomózis lokalizációja, disztális bifurkáció potenciális jelenléte, meszesedés foka, a perikardiális hegesedés miatti epikardiális koronáriák merevsége, koronária-tortuozitás, „tenting" jelenség [zsugorodott SVG által felhúzott érlefutás mindig a graftba vezeti mind az antero-, mind a retrográd eszközöket és néha lehetetlenné teszi az éles kanyar bevételét a "sátor” tetején]) $(4,5)$. Jelen esetünkön keresztül ismertetjük a kettős lumenü mikrokatéter (a rapid exchange [RX] disztális port és proximális over-the-wire [OTW] oldalsó port struktúra szimultán 2 vezetődrót bevezetését teszi lehetővé) hasznosságát anterográd és retrográd drótozás esetében, amely komplex anatómiai helyzetekben nyújthat effektív megoldást speciális CTO-intervenciókban (poszt-ACBG, bifurkáció).

\section{Esetismertetés}

A 75 éves férfi beteg kórelőzményében hipertenzió, dyslipidaemia, inzulinnal kezelt 2-es típusú diabetes mellitus szerepelt. Revaszkularizációs anamnézisből kiemelendő 1999 RCA (right coronary artery) PCI (bare metal stent, BMS), 2000-ben RCA stentokklúzió és reziduális szükületek miatti ACBG-mütét (LIMA-LAD, SVG-CXOM, SVG-RCA, SVG-I. diagonális ág), valamint 2016-ban az RCA véna graft okklúziója miatti graft $\mathrm{PCl}$ (drug eluting stent, DES). Rekurráló panaszok miatt 2018-ban elvégzett koronarográfia során okkludált véna graftok igazolódtak (SVG-RCA, SVG-diagonális ág, SVG-CXOM), amely miatt első lépésben $\mathrm{CX} P C l$ történt (DES). Kardiális mágneses rezonancia (cMR) által igazolt hátsófali viabilitás igazolása után és optimális gyógyszeres terápia beállitása ellenére perzisztáló panaszok (CCS 2-3 angina ekvivalens fulladás) miatt hazánk egy másik centrumában két alkalommal is sikertelen anterográd RCA-rekanalizációs kísérletet végeztek. Ezt követően vettük fel a betegünket ismételt jobb koronária-revaszkularizációs kísérlet elvégzése céljából.

Bal arteria radialis és jobb arteria femoralis punkcióját követően 7 French EBU 4.0 valamint 7 French AL 1.0 katéterekkel kanüláltuk a bal közös törzset, illetve a jobb koronária-szájadékot. Bilaterális injekció alapján (1. ábra A panel) aneurizmatikusan tágult proximális

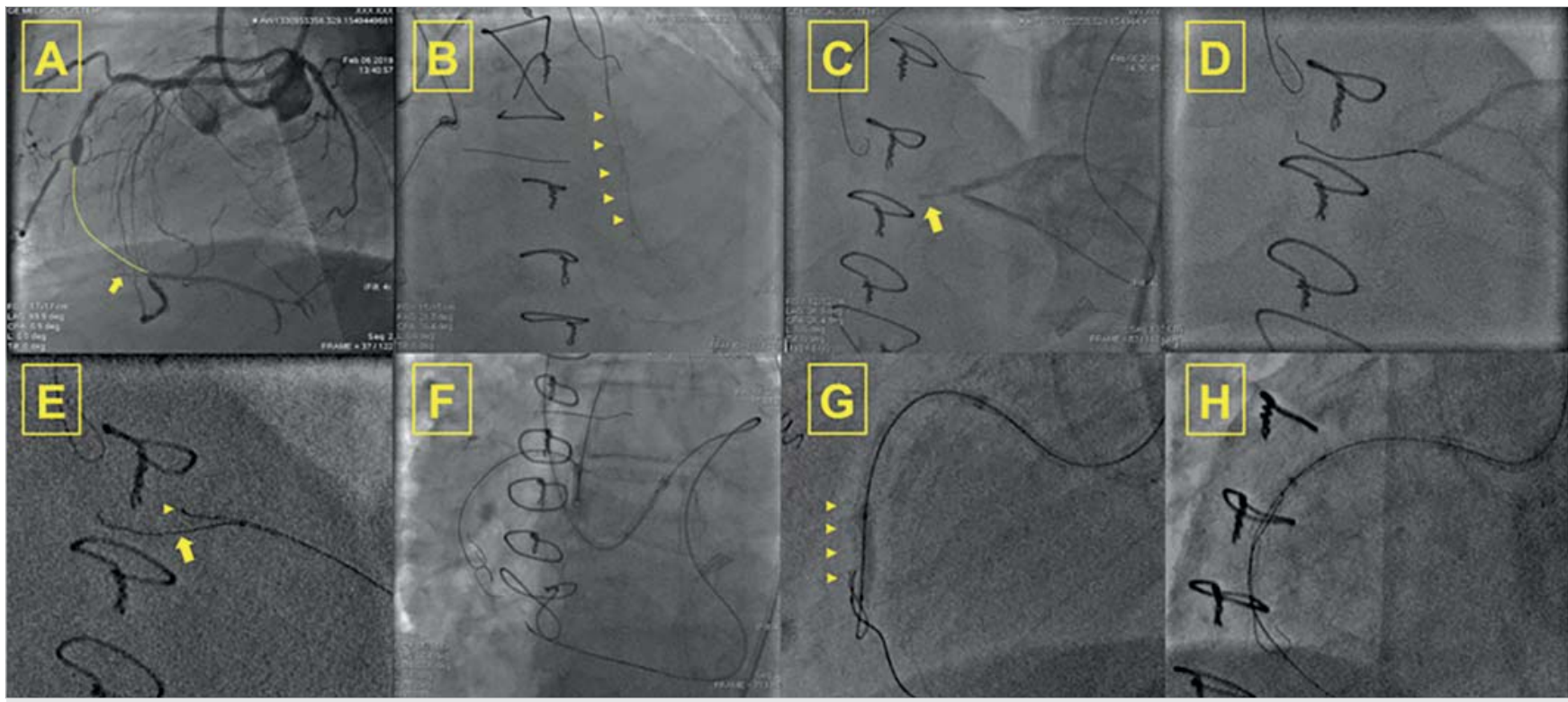

1. ÁBRA. Kettős lumenű mikrokatéter retrográd alkalmazása krónikus teljes koronária-okklúzió (CTO) perkután intervenciója (PCl) során. A: Bilaterális injekció reprezentálja a crux-ig terjedő disztális jobb koronária krónikus okklúziójának disztális és proximális anatómiáját. B: Retrográd mikrokatéter (Corsair Pro [Asahi Intecc. Nagoya, Japan]) tip injekciója. C: Sikeres disztális CTO-sapkához történő drótozás (Sion [Asahi Intecc. Nagoya, Japan], Corsiar Pro). D: Saphena graftba parkolt Confianza Pro 12 vezetődrót [Asahi Intecc. Nagoya, Japán]. E: Retrográd kettős lumenű mikrokatéter (Sasuke [Asahi Intecc. Nagoya, Japán]) alkalmazása a disztális sapka over-the-wire (OTW) porton keresztül történő punkciójához. F: Anterográd es retrográd „knuckle" drótok (Fielder XT, Pilot 200 [Asahi Intecc. Nagoya, Japan]) koaxiális pozícióban. G: Sikertelen reverz CART (controlled antegrade and retrograde subintimal tracking) retrográd disszekció és re-entry technika a vertikális jobb koronáriaszakaszon. H: GuideLiner (Vascular Solutions, Minneapolis, MN, USA) reverz CART technika vezérelte vezetődrót belepés az anterográd vezetőkatéterbe 
RCA, tompa okklúziós sapka, valamint kielégítő disztális retrográd telődés (Rentrop 2-3, dominánsan szeptális kollaterálisokon keresztül) volt detektálható. Kezdő stratégiaként anterográd drót eszkalációt kíséreltünk meg Gaia 2 és Fielder XT (mindkettő Asahi Intecc, Nagoya, Japán) vezetődrótok és Corsair Pro (Asahi Intecc, Nagoya, Japán) mikrokatéter szupportjával. Rövid próbálkozások után azonban szubintimális drótpozíció volt sejthető, így „knuckle” drót segítségével tompa preparálással jutottunk a disztális jobb koronáriaszakaszba, majd egy rendkívül kemény, áthatolhatatlan szegmentum miatt retrográd technikára tértünk át. Kontrasztanyag-vezérelt drótozás révén (mikrokatéter tip injekciók [1. ábra $B$ panel]) sikeresen passzáltuk a szeptális kollaterális csatornát (Sion [Asahi Intecc, Nagoya, Japán] Corsair Pro). Többszöri próbálkozás ellenére sem sikerült azonban a disztális sapkát áttörni (1. ábra $C$ panel) (Fielder XT, Gaia 3, Sion), mivel a már említett „tenting” jelenség miatt ismételten a disztális jobb koronária-bifurkáció előtt anasztomizált okkludált véna graftba jutottunk (Confianza Pro 12 [Asahi Intecc, Nagoya, Japán]). A komplex anatómia megoldásaként a véna graftba parkolt vezetődrótot (1. ábra $D$ panel) felhasználva Sasuke kettős lumenü mikrokatétert juttattunk (Asahi Intecc,
Nagoya, Japán) abba, majd annak oldal-portján (OTW port) keresztül megfelelő szupportot és irányt tudtunk biztosítani a második retrográd drót sikeres disztális sapka punkciójához (1. ábra E panel) (Miracle 6 [Asahi Intecc, Nagoya, Japán]). Következő lépésben a Sasuke mikrokatétert Corsair Pro-ra cserelve retrográd Pilot 200 (Asahi Intecc, Nagoya, Japán) „knuckle” drót segítségével megfelelő koaxiális drótpozíciót vettünk fel az anterográd drót magasságában (1. ábra $F$ panel). GuideLinerrel (Vascular Solutions, Minneapolis, MN, USA) asszisztált reverz CART (controlled antegrade and retrograde subintimal tracking) technikával sikeresen az anterográd vezető katéterbe jutottunk (1. ábra $G$ és $H$ panel). Ezt drót externalizáció követte, azaz $330 \mathrm{~cm}$-es RG3 (Asahii Intecc., Nagoya, Japán) drótot juttatunk a retrográd vezető katéter felől a mikrokatéter lumenen át az anterográd vezető katéterbe, majd ezt anterográd vezetődrótként használva ballon predilatációt végeztünk az okkludált szegmentumban. Kontralaterális angiogramok és szimultán disztális RCA-ballon infláció útján győződtünk meg arról, hogy a cruxban retrográd disszekció alakult ki. Ezzel a vizualizációs technikával elkerülhettük az anterográd disszekciós tasak hidraulikus expanzióját. Tekintettel a disszekcióra és az oldalág megőrzés

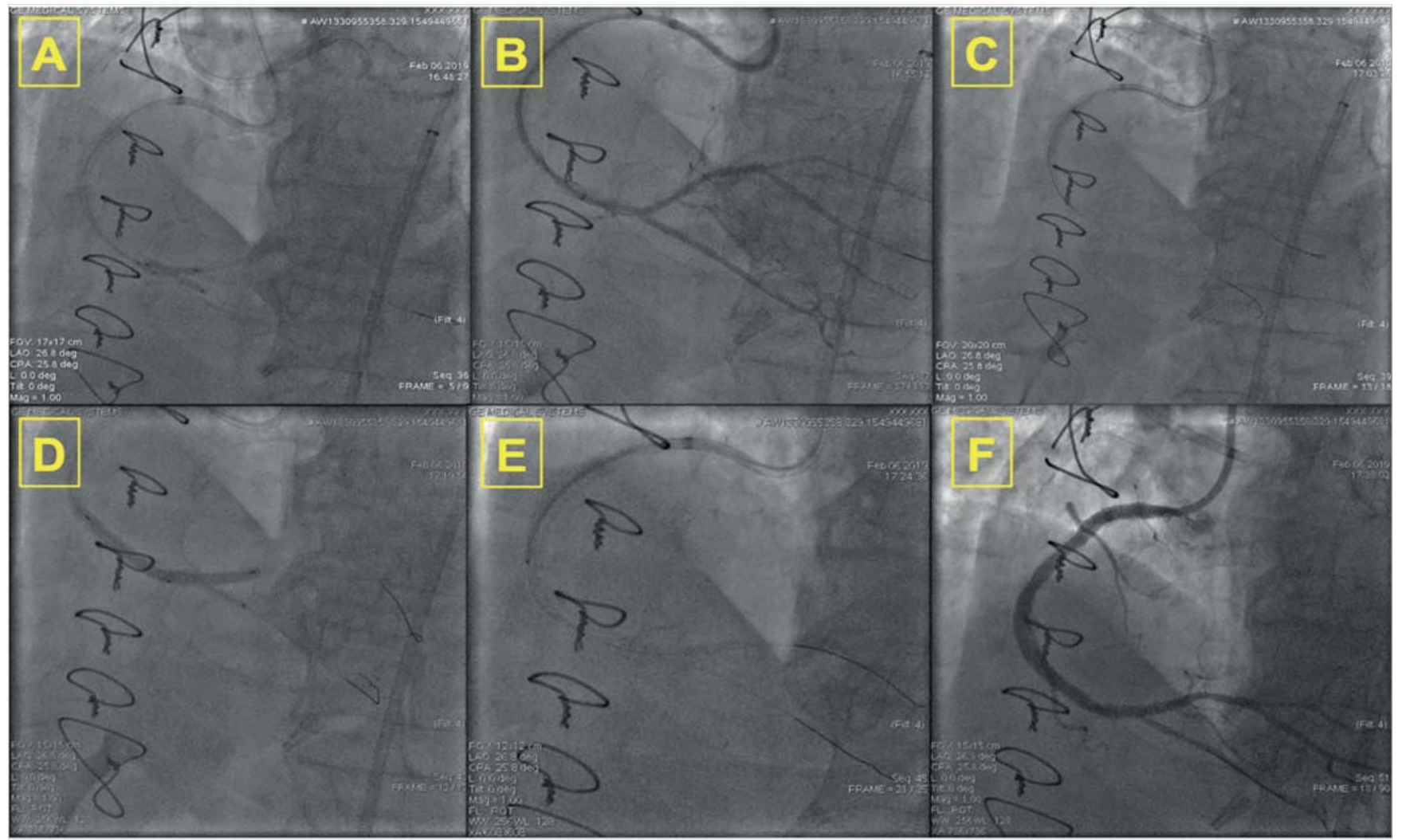

2. ÁBRA. Kettős lumenű mikrokatéter anterográd alkalmazása krónikus teljes koronária-okklúzió (CTO) perkután intervenciója (PCl) során. A: Kissing-ballon tágítás a poszterolaterális oldalág kettős lumenű Sasuke (Asahi Intecc. Nagoya, Japan) való újradrótozást követően. B: GuideLiner (Vascular Solutions, Minneapolis, MN, USA) facilitált angiográfia, amely perzisztáló crux disszekciót mutat. C: Sasuke asszisztált poszterior descendens ág drótozás majd externalizált dróteltávolítás. D: „Crossover" stentelés a poszterolaterális ág fele. E: Proximális stent-implantáció reziduális proximális disszekció miatt. F: Sikeres jobb koronária CTO-intervenció 3 gyógyszerkibocsájtó stent implantációjával 
fontosságára, a poszterolaterális $(\mathrm{PL})$ ág drótozásához ismetelten a Sasuke kettős lumenü mikrokatétert használtuk, majd kissing dilatációkat végeztünk a crux bifurkációjában (2. ábra $A$ panel). A perzisztáló jobb koronária crux disszekció miatt (2. ábra $B$ panel) ismetelten a kettős lumenú mikrokatétert alkalmaztuk - ezúttal az anterográd PL-drótra vezetve - és az OTW-lumenen át újra drótozást végeztünk a poszterior descendens (PD) ágba (2. ábra $C$ panel). Ezt követően a retrográd externalizációs drótot már biztonsággal eltávolíthattuk, hiszen mindkét ágban biztosan intraluminális anterográd drót állt rendelkezésünkre. A PL-ág felé „crossover” stentelést végeztünk (2. ábra $D$ panel), majd a Sasuke mikrokatéter segítségével a stent cellákon át a PD-ágat ismételten drótoztuk. Utolsó lépésben kissing utótágítást végeztünk és két addicionális gyógyszerkibocsátó stentet helyeztünk be (2. ábra $E$ panel), jó angiográfiás végeredménnyel (2. ábra $F$ panel) (kontrasztanyag 320 ml, procedurális idő 257 min, sugár dózis 2,114 Gray). A beteget, 48 órás eseménytelen obszervációját követően, stabil és panaszmentes állapotban otthonába bocsájtottuk.

\section{Megbeszélés}

Irodalmi ismereteink szerint esetünk egyedülállóan mutatja be retrográd kettős lumenü mikrokatéter többszörös alkalmazását korábban ACBG-mütéten átesett beteg CTO rekanalizációja céljából (3. ábra). Ennek során 1. az eszközt retrográd úton szeptális kollaterálison át a disztális föágba hatolásra;
2. anterográd irányban a disszekált PL-ág lumenének elérésére;

3. anterográd irányban a PD-ág lumenének elérésére;

4. crossover stenten át a PD-ág újradrótozására használtuk.

Esetünk azt példázza, hogy komplex technikák alkalmazása fontos sarokpontja a krónikus okklúziók megnyitásában az oldalágvesztés elkerülésének, mely meghatározó lehet a hosszú távú poszt-PCl-mortalitás csökkentésében.

Számos tanulmány vizsgálta az ACBG-mútött betegekben végzett CTO-rekanalizációk eredményeit rövid és hosszú távon. Christopoulos és munkatársai 496 betegben vizsgálták a hibrid algoritmus alkalmazását CTO PCl-ben post-ACBG-betegekben ( $n=176,35 \%)$, ACBG nélküli csoporttal összehasonlítva $(n=320)(4)$. Az ACBG-betegekben gyakrabban volt szükség retrográd technikák alkalmazására (39\% vs. $24 \%, p<0,001)$, valamint az intervenciós sikerarány $(88 \%$ vs. $93 \%$, $p=0,04)$ csökkenő tendenciát mutatott, megfelelően reprezentálva ezen klinikai esetek komplexitását. Ugyanakkor a beavatkozást követően nem mutatkozott számottevő különbség a szövődményeket illetően (major adverse cardiac event, MACE; $2,1 \%$ vs. $1,1 \%$, $\mathrm{p}=0,40)$. Azzalini és munkatársai hasonló tendenciájú klinikai sikerarányt találtak 2058 esetszámú (ACBG [n=401] 82\% vs. non-ACBG [ $n=1657$ ] 88\%, $p=0,001)$ heterogén betegpopulációban (multicentrikus vizsgálat) (5). Ezen tanulmány alapján - a korábbiakkal ellentétben - szignifikánsan magasabb periprocedurális komplikáció ráta (MACE, 3,7\% vs. 1,5\%, p=0,0004), és medián 377 napos utánkövetési idővel magasabb kar-

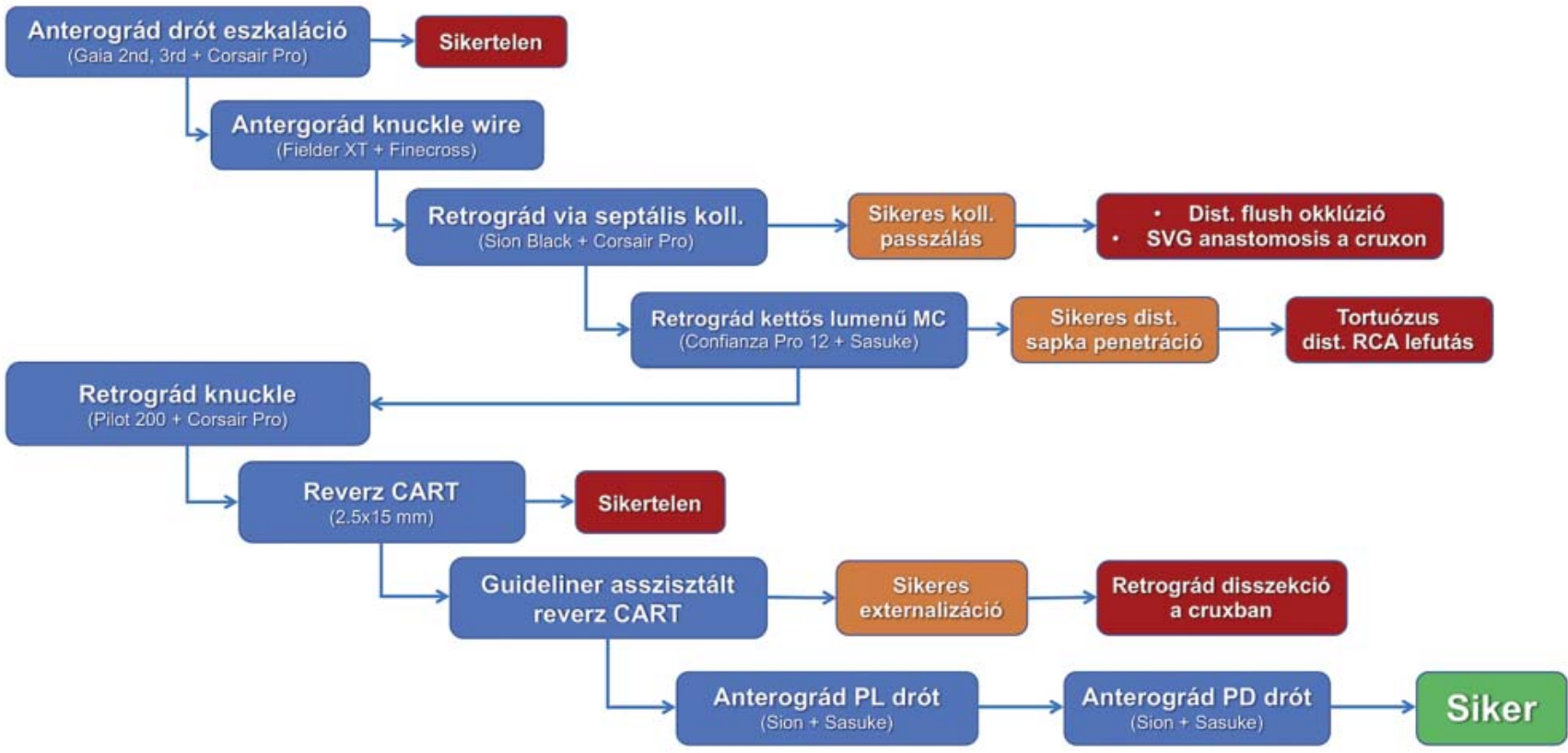

3. ÁBRA. Retrográd es anterográd kettős lumenű mikrokatéter facilitált jobb koronária krónikus teljes okklúzió perkután intervenciójának vázlatos lépései (CART: controlled antegrade and retrograde subintimal tracking; MC: mikrokatéter; PD: posterior descendens; PL: poszterolaterális; RCA: right coronary artery; SVG: saphena véna graft) 


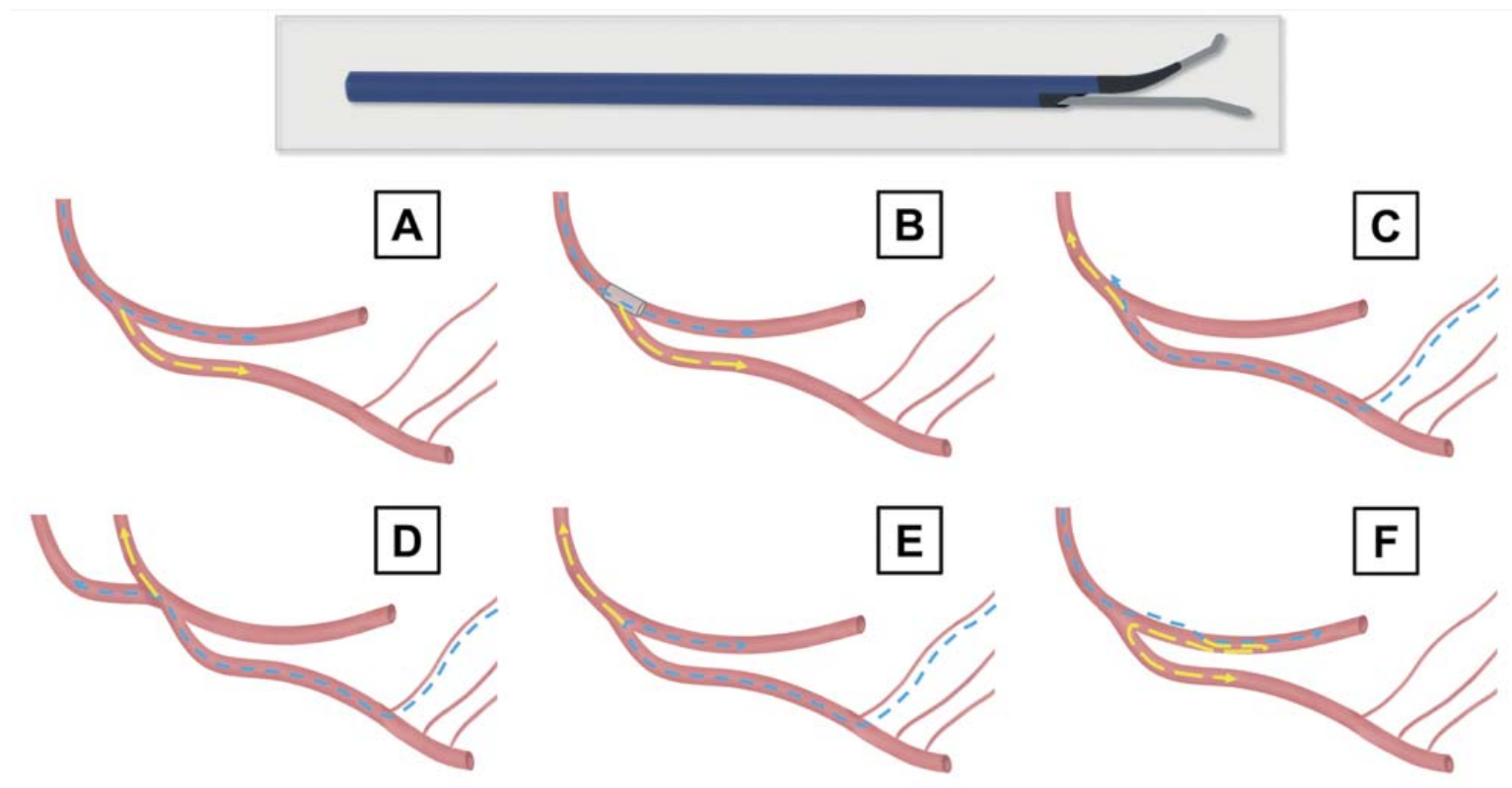

4. ÁBRA. A kettős lumenű mikrokatéter felhasználási lehetőségei bifurkáció drótozás esetén („over-the-wire” port [OTW, sárga], „rapid-exchange” port [RX, kék]). A: Anterográd bifurkáció-drótozás. B: Anterográd bifurkáció (újra) drótozás „stent strutok"-on keresztül. C: Retrográd parallel drótozás szubintimálisan parkolt első retrográd dróton (RX) felvezetett kettős lumenű mikrokatéter "over the wire" (OTW) portját felhasználva. D: Retrográd kettős lumenű mikrokatéter felhasználása SVG-graftban parkolt RX-drót, és OTW-oldalport drót segítségével. E: Retrográd poszterior descendens $(\mathrm{PD})$ poszterolaterális $(\mathrm{PL})$ drótozás RX-porton, majd OTW-porton keresztüli disztális sapkapunkció. F: Disztális re-entry-t követően a valódi lumenben parkolt RXdrót, és reverz OTW-drót segítségével történő bifurkációs oldalágdrótozás anterográd úton

diális mortalitás $(3,8 \%$ vs. $1,9 \%, p=0,02)$, „target” lézió re-intervenció $(11,5 \%$ vs. $6,6 \%, p<0,001)$, és „target” lézió területi miokardiális infarktusban $(2,0 \%$ vs. $0,7 \%$, $\mathrm{p}=0,04)$ mutatkozott az ACBG-csoportban. Mindemellett az ACBG-mútöttek CTO-intervenciójához felhasznált kontrasztanyag-mennyiség, sugárdózis es procedurális idő is szignifikánsan meghaladja a non-ACBG CTO-intervenciókét $(3,4)$. Ezen legfrissebb tanulmányok alátámasztják, hogy előzetes ACBG-mütét után elzáródott SVG-ok mellett a CTO perkután intervenciója rendkívül komplex beavatkozás. Európai statisztikai adatok alapján ritkábban találkozunk ACBG utáni CTOval $(15-22 \%)(1,2,6)$ mint az Egyesült Államokban $(28-37 \%)(3,4)$.

A jelentős oldalágak megőrzése valamint a periprocedurális infarktus elkerülése CTO PCI során kritikus fontosságú a betegek hosszú távú mortalitásának csökkentésében $(7,8)$. Az okklúzió szegmentumában eredő nagy oldalág (okklúziótól proximálisan, az okklúzió magasságában, valamint okklúziótól disztálisan) elfordulási incidenciája 26,5-33,0\% közöttire tehető a perkután intervenciós kísérleten áteső betegek körében (9). Tekintettel arra, hogy minden 3. esetben a bifurkáció is érintett speciális „oldalág-mentési” technikákra lehet szükség. A proximális oldalág elsősorban horgonyzási technikák alkalmazásában lehet releváns, valamint preventív drótozás válhat szükségessé az anterográd drót eszkaláció megkezdése előtt, ugyanakkor oldalágvesztés lehetőségével ritkán, csak retrográd, súlyosan propagálódó disszekció esetén érdemes számolnunk. Ezzel szemben az okklúzió testében, valamint az elzáródás disztális sapkájánál eredő oldalág megőrzése jelentős mertekben csökkenti a beavatkozás klinikai sikerarányát (3).

Bemutatott esetünk jól szemlélteti az ACBG és bifurkációk együttese által okozott technikai akadályokat CTO $\mathrm{PCl}$ során, amelyek azonban a megfelelő eszközök használatával áthidalhatók. A retrográd mikrokatéterek használata jelentős mértékben függ a kollaterális méretétől és annak tortuozitásától (szeptális, epikardiális, vagy saphena véna graft), ezért a megfelelő mikrokatéter választásában a tip profiljának és átmerőjének fontos szerepe van. Habár több kettős lumenú mikrokatéter érhető el világszerte (Twin-Pass, Twin-Pass Torque [mindkettő Teleflex, Wayne, PA, USA], Crusade [Kaneka, Tokió, Japán], Fine Duo [Terumo, Tokió, Japán], NHancer [IMDS, Roden, Hollandia]), az általunk hazánkban elsőként alkalmazott Sasuke az egyedüli biztosságosan alkalmazható alacsony tip-profilú katéter, amely a szeptális kollaterálisok többségén is biztonságosan átvezethető (tip átmerő 1,5 Fr vs. 1,8 Fr [Fine Duo] vs. 2,0 Fr [Twin-Pass] vs. 2,1 Fr [Twin-Pass Torque] vs. 2,2 Fr [Crusade], 2,3 [NHancer]). Epikardiális kollaterálisokon keresztüli applikációja jelenleg nem került leírásra, és ennek magasabb perforáció rizikó miatt a használatát jelenleg nem javasoljuk. Ezen speciális esetünkben egyedülállóan „kihorgonyoztuk” a retrográd mikrokatétert az okkludált SVG disztális sza- 
kaszán, amely kellő szupportot adott a kemény disztális sapka második dróttal történő penetrációjához (4. ábra $D$ panel). Mindemellett a retrográd kettős lumenú mikrokatéter alkalmazható sikeres PL-PD, vagy PD-PL-ág drótozásakor (véna graft involválása nélkül) a disztális sapka punkciójához (4. ábra $E$ panel). A kettős lumenü mikrokatéter alkalmazása retrográd parallel drótozásra is használható, mely szubintimális retrográd drótpozíció mellett az OTW-port használatával a második vezetődrót révén az intraluminális pozíció visszanyerhető (10) (4. ábra C panel). Ugyanakkor kiemelendő, hogy a kettős lumenủ mikrokatéterek alkalmazása elsősorban disztális tip profiljuk miatt dominánsan anterográd drótozáshoz használatosak (4. ábra $A$ panel). Főbb alkalmazási indikációs köréhez tartozik továbbá a szubintimális drótpozíciót követően egy második vezetődróttal történő „reentry” a disztális valódi lumenbe, valamint okklúziós test, illetve disztális sapkabifurkáció esetén anterográd drótozáshoz (4. ábra $F$ panel). Két stentes bifurkációs technika alkalmazásakor a kettős lumenű mikrokatéter szinten kiválóan alkalmas a stent cellákon keresztüli vagy éles szögben eredő oldalágba bejutás megkönnyítésére (4. ábra $B$ panel).

\section{Következtetések}

A kettős lumenű mikrokatéterek hasznos eszközként szolgálhatnak a bifurkációt érintő és/vagy elzáródott graft által megnehezített natív krónikus teljes koronária-okklúzió intervenciókban, megkönnyítve az anterográd és retrográd drótozást az oldalág megőrzését.

\section{Irodalom}

1. Wilson WM, Walsh SJ, Yan AT, et al. Hybrid approach improves success of chronic total occlusion angioplasty. Heart 2016; 102 :
1486-93. DOI:10.1136/heartjnl-2015-308891

2. Maeremans J, Walsh S, Knaapen P, et al. The Hybrid Algorithm for Treating Chronic Total Occlusions in Europe: The RECHARGE Registry. J Am Coll Cardiol 2016; 68: 1958-1970. DOI: 10.1016/j. jacc.2016.08.034

3. Tajti P, Karmpaliotis D, Alaswad K, et al. The Hybrid Approach to Chronic Total Occlusion Percutaneous Coronary Intervention: Update From the PROGRESS CTO Registry. JACC Cardiovasc Interv 2018. DOI:10.1016/j.jcin.2018.02.036

4. Christopoulos G, Menon RV, Karmpaliotis D, et al. Application of the "hybrid approach" to chronic total occlusions in patients with previous coronary artery bypass graft surgery (from a Contemporary Multicenter US registry). Am J Cardiol 2014; 113: 1990-4. DOI:10.1016/j.amjcard.2014.03.039

5. Azzalini L, Ojeda S, Karatasakis A, et al. Long-Term Outcomes of Percutaneous Coronary Intervention for Chronic Total Occlusion in Patients Who Have Undergone Coronary Artery Bypass Grafting vs Those Who Have Not. Can J Cardiol 2018; 34: 310-318. DOI:10.1016/j.cjca.2017.12.016

6. Galassi AR, Sianos G, Werner GS, et al. Retrograde Recanalization of Chronic Total Occlusions in Europe: Procedural, In-Hospital, and Long-Term Outcomes From the Multicenter ERCTO Registry. J Am Coll Cardiol 2015; 65: 2388-400. DOI: 10.1016/j. jacc.2015.03.566

7. Jang WJ, Yang JH, Choi SH, et al. Association of periprocedural myocardial infarction with long-term survival in patients treated with coronary revascularization therapy of chronic total occlusion. Catheter Cardiovasc Interv 2016; 87: 1042-9. DOI:10.1002/ccd.26286

8. Galassi AR, Boukhris M, Tomasello SD, et al. Incidence, treatment, and in-hospital outcome of bifurcation lesions in patients undergoing percutaneous coronary interventions for chronic total occlusions. Coron Artery Dis 2015; 26: 142-9. DOI: 10.1097/ MCA.0000000000000194

9. Ojeda S, Pan M, Gutierrez A, et al. Bifurcation lesions involved in the recanalization process of coronary chronic total occlusions: Incidence, treatment and clinical implications. Int J Cardiol 2017; 230 432-438. DOI: 10.1016/j.ijcard.2016.12.088

10. Tanabe G, Oikawa Y, Yajima J, Matsuno S, Kano H, Yamashita T. Retrograde parallel wire technique using a dual lumen catheter can be useful for percutaneous coronary intervention with chronic total occlusion. J Cardiol Cases 2018; 17: 25-28. DOI: 10.1016/j. jccase.2017.08.014 